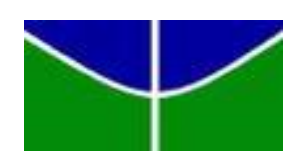

Universidade de Brasília (UnB)

Centro de Estudos Avançados Multidisciplinares (CEAM)

Programa de Pós-Graduação em Direitos Humanos e Cidadania (PPGDH)

VANESSA RODRIGUES DE ARAÚJO

\title{
O RESGATE DA MEMÓRIA FAMILIAR INDÍGENA: \\ um estudo sobre o direito humano de saber quem se é
}


VANESSA RODRIGUES DE ARAÚJO

\title{
O RESGATE DA MEMÓRIA FAMILIAR INDÍGENA: um estudo sobre o direito humano de saber quem se é
}

\begin{abstract}
Dissertação de Mestrado apresentada ao Programa de Pós-Graduação em Direitos Humanos e Cidadania da Universidade de Brasília, como requisito parcial para a obtenção do título de Mestre em Direitos Humanos e Cidadania.

Linha de Pesquisa: Direitos Humanos, Democracia, Construção de Identidades/Diversidades e Movimentos Sociais.
\end{abstract}

Orientadora: Profa. Dra. Rita Laura Segato

Brasília 
VANESSA RODRIGUES DE ARAÚJO

\section{O RESGATE DA MEMÓRIA FAMILIAR INDÍGENA: UM ESTUDO SOBRE O DIREITO HUMANO DE SABER QUEM SE É}

Dissertação de Mestrado apresentada ao Programa de Pós-Graduação em Direitos Humanos e Cidadania da Universidade de Brasília como requisito parcial para a obtenção do título de Mestre em Direitos Humanos e Cidadania. Linha de Pesquisa: Direitos Humanos, Democracia, Construção de Identidades/Diversidades e Movimentos Sociais.

Orientadora: Profa. Dra. Rita Laura Segato

Aprovada em:

BANCA EXAMINADORA:

\footnotetext{
Profa. Dra. Rita Laura Segato - Orientadora FCS/UnB

Profa. Dra. Cléria Botelho da Costa - Membro HIS/UnB
}

Prof. Dr. Wanderson Flor do Nascimento - Membro IH/FIL/UnB 
À minha avó: meu orgulho, minha inspiração;

Ao meu sobrinho Guilherme, para que não esqueça sua origem;

A todas as mães índias. 


\section{Agradecimentos}

A decisão em realizar o mestrado em direitos humanos na Universidade de Brasília (UnB) foi motivada pela busca por emancipação não só acadêmica como subjetiva. Muitas vezes, durante esta caminhada, tive que levar a minha angústia para passear e ela acabou aprendendo que tudo o que é feito com amor pode até exigir tarefas difíceis, mas são essas tarefas que possibilitam derrubar qualquer tipo de formatação ditadora que construímos dentro de nós. Não há problema algum em nadar contra a maré. A grande maravilha deste processo está na compreensão positiva do viver-sentir.

Foi extremamente desafiante compartilhar aqui um pouco da minha história e transformar o meu projeto de vida neste lindo trabalho acadêmico, cheio de gritos políticos. Inicio aqui minha militância em prol de uma memória que nos guie até as nossas origens. Nem todo silêncio será esquecido! Registro a grande satisfação de ter deixado o meu coração dirigir a minha vida.

Com imensa gratidão, agradeço aos meus pais, Anna Cláudia e Gilton, por terem me ensinado o valor da humildade, pelas orações, por compreenderem a minha escolha e por todo apoio ao longo da minha jornada.

Meus agradecimentos sinceros a minha família, responsável por despertar este projeto de vida. Toda a minha gratidão por terem, mesmo nos momentos mais dolorosos, rompido com o fantasma do silêncio. Tenho muito orgulho da nossa história e de quem nós somos. Espero que vocês sintam neste trabalho o perfume do nosso lar. Amo vocês!

Agradeço especialmente e infinitamente ao meu companheiro, leitor e ouvinte Tiago Borges, por naturalmente gostar de fazer parte dos meus sonhos, por compreender todas as minhas insatisfações crônicas e eternas (motores da minha engrenagem), por todo amor incomum, força, lealdade, e por caminhar junto comigo sempre com fé e luz.

À minha orientadora e mentora não só acadêmica, mas de vida, Rita Laura Segato, pelos ensinamentos que me libertaram de diversas prisões. Agradeço por todo carinho, credibilidade e encorajamento. Sem você este trabalho não seria possível! Serei extremamente grata ao universo por nossos caminhos terem se cruzado.

Ao professor Wanderson Flor do Nascimento, pela sensibilidade, empolgação e por todas as contribuições e ensinamentos enriquecedores durante esta caminhada.

Às minhas amigas da vida, também companheiras do mestrado, Yane Silva e Ana Paula Rodrigues, pelas conversas libertadoras e acalentadoras, pela escuta, por todo carinho, sensibilidade, apoio, boas vibrações e longas risadas. Vocês foram a minha primavera 
desta caminhada acadêmica. Aninha, sua essência otimista me encanta! Y, como você mesma diz as conversas de "útero para útero" são fundamentais!

Ao meu amigo Marcelo Rios, que mesmo morando na Bolívia esteve muito presente. Grata por todo o carinho, pelas diversas e ricas conversas, por dividir suas grandiosas experiências de vida e de trabalho que por muitas vezes trouxeram esperança. Espero reencontrá-lo em breve!

À amiga e colega do mestrado Olga Brigitte, por ter colhido a semente da minha luta e ter reconstruído em seu seio familiar a sua árvore genealógica.

À amiga Helga Martins, por todo carinho, empatia, sinceridade e pela troca de ideias.

À amiga e colega de mestrado Vannessa Carneiro por todo apoio, entusiasmo e pelas comemorações.

Às minhas amigas da AGU Ana Claudia Freitas, Talitha de Lira, Claudia Ferreira, Júlia Lopes e Suelene Rodrigues pela torcida e por permanecerem pronunciando o sotaque do amor nesses quase seis anos de amizade.

Ao corpo docente do Programa de Pós-Graduação em Direitos Humanos e Cidadania (PPGDH): Rita Laura Segato, Vanessa Maria de Castro, Alexandre Araújo Costa, Menelick de Carvalho Netto, José Geraldo de Sousa Junior, bem como Cléria Botelho da Costa, Nair Heloisa Bicalho de Sousa, Regina Lucia Sucupira Pedroza e Maria Salete Kern Machado, pela calorosa recepção na Universidade de Brasília (UnB) e pela sensibilidade durante a troca de saberes.

Ao professor César Augusto Baldi pelos ensinamentos. Como admiro a sua erudição!

Agradeço a CAPES pela concessão, mesmo tardia, da bolsa.

Enfim, meus agradecimentos afetuosos são para todos que me incentivaram, compreenderam, ouviram com carinho e respeitaram esta caminhada. 


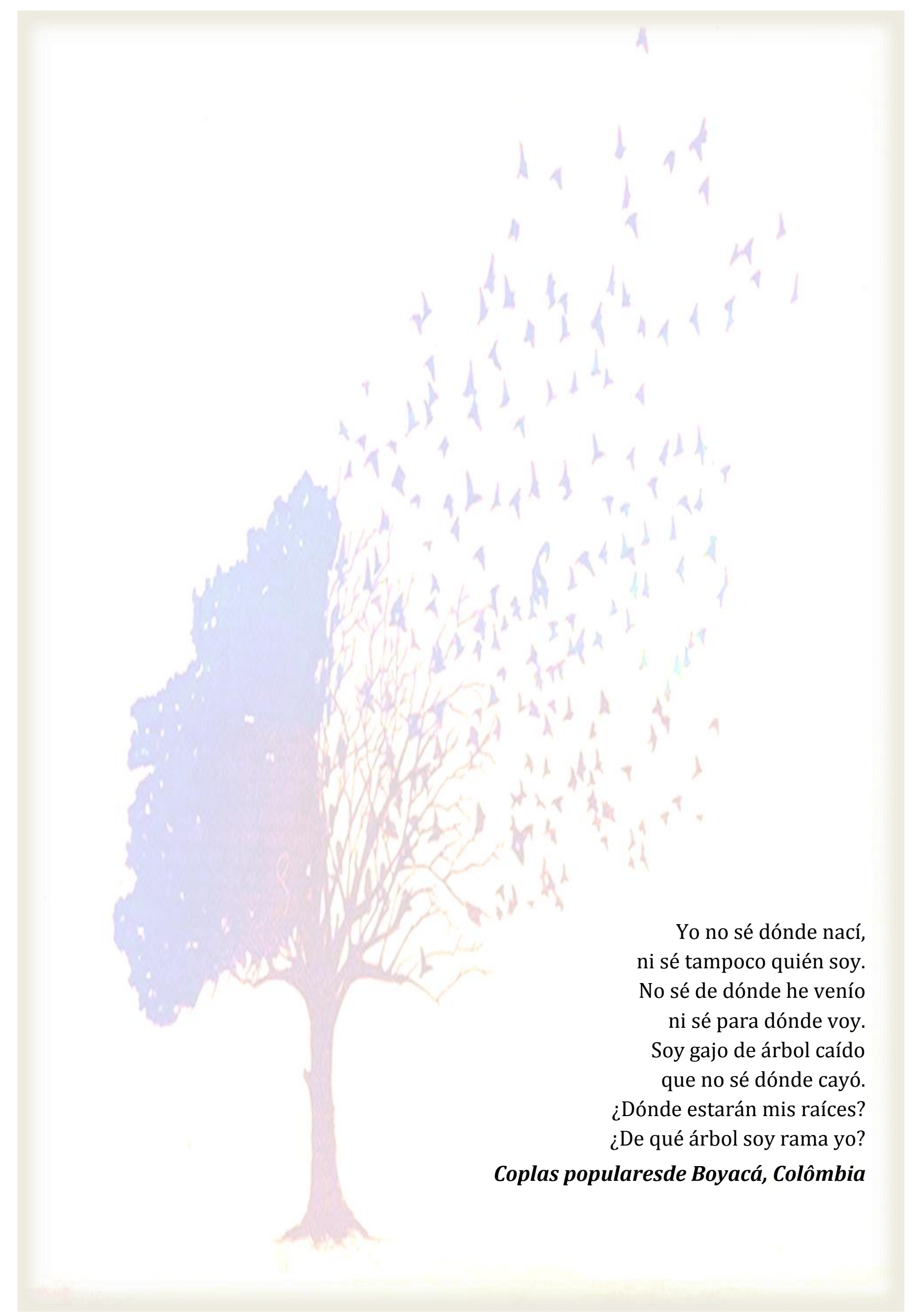




\section{Resumo}

Este trabalho consubstancia-se em uma crítica ao processo de censura das nossas genealogias raciais. A escrita desta pesquisa decorreu de uma pulsão ética provocada por uma dor que habita na ausência. A memória da minha avó foi ocultada por quase duas décadas no meu seio familiar devido à sua raça indígena. Por esta razão, utilizei-me do instrumento metodológico da autoetnografia e da etnografia familiar que vem sendo desenvolvida desde a minha infância para debater a memória a partir de uma perspectiva racial, bem como apontar os possíveis mecanismos de aniquilação desta. A raça foi trabalhada, com base nas teorias descoloniais, como uma construção histórica que nasce com a modernidade (Quijano), bem como um signo capaz de revelar as nossas origens (Segato). Aponto que as linhas teóricas da memória e a produção do sentido da memória foram construídas a partir de perspectivas históricas binaristas: moderno/não moderno, europeu/não europeu, que marginalizou histórias e sujeitos que carregam a marca da colonialidade em seus corpos. Esta construção de um tempo homogêneo de linear expurgou o "outro" da história da humanidade. O evento sobre o etnocídio colonial nas Américas - que resultou num esquecimento coletivo sobre quem se é aparece de forma tímida nos debates internacionais e permanece silenciado nos campos de debates nacionais sobre a memória, mesmo a memória sendo um direito humano. Ao realizar uma busca em doze documentos de direitos humanos de âmbito global e regional, de uma menção à memória capaz de devolver a consciência histórica àqueles que, assim como eu, desconhecem sua origem familiar, não encontrei nos textos normativos pesquisados o "direito à memória" como um dever a ser garantido pelo Estado. Atribuí a existência dessa lacuna (falta de positivação) à linguagem colonizadora dos direitos humanos, que ao essencializar o ser humano à imagem do homem branco europeu (jusnaturalismo) e ao utilizar a lei como única via para a compreensão de realidades (juspositivismo) se constituiu em um discurso homogêneo que silenciou o processo de significação histórica de povos distintos. A partir desta ótica, aponto a insatisfação ética como uma possibilidade de expandir os direitos humanos de modo a incluir direitos capazes de nomear a dor, como se trata o direito humano de saber quem se é. Posteriormente, discuto que a memória relativa a esse direito, por se tratar de um resgate do que está vivo em nós - e, não, de memória de mortos -, portanto, de um elemento constitutivo de nossas identidades, segue na contramão das formas modernas de saber sobre o passado. 0 tempo passado ao qual me refiro se apoia numa visão de passado heterogêneo, ou seja, não se confunde com o passado enquanto período anterior à modernidade. Por fim, indago sobre a possibilidade de se construir uma memória viva sobre nossas linhagens raciais que se hospede em nós.

Palavras-chave: Autoetnografia. Colonialidade. Raça. Memória familiar. Direitos humanos. 


\begin{abstract}
\end{abstract}
This research is focused into a criticism of the censorship process of our racial genealogies. The writing of this research took place in an ethical impulse caused by pain that inhabits absence. The memory of my grandmother was hidden for nearly two decades in my family environment due to its indigenous race. For this reason, I used me from a methodological tool of autoethnography and family ethnography that has been developed since my childhood to discuss memory from a racial perspective as well as point out the possible annihilation mechanisms of it. The race was crafted based on decoloniality theories, as a historical building that is born with modernity (Quijano), as well as a sign able to reveal our origins (Segato). I indicate that the theoretical lines of memory and the production of sense memory were built from binary historical perspectives: modern / not modern, European / non-European, which marginalized stories and subjects that carry the mark of coloniality in their bodies. This building a linear homogeneous time purged the "other" in human history. The event on the colonial ethnocide in the Americas - which resulted in a collective forgetfulness about who you are - appears timid in international debates and remains muted in the fields of national debates about memory, even the memory being a human right. When performing a search in twelve human rights documents of global and regional level, a reference to the memory capable of restoring historical consciousness to those who, like me, are unaware of their descent, not found in the normative texts surveyed the "right to memory "as a duty to be guaranteed by the state. Assign the existence of this gap (lack of assertiveness) to the colonial language of human rights, which the essentialize human being in the image of the white European man (legal naturalism) and using the law as the only way to understand reality (legal positivism) was constituted in a homogeneous speech that silenced the historical significance of the process of distinct peoples. From this perspective, I consider the ethical dissatisfaction as an opportunity to expand human rights to include rights able to name the pain, as it is the human right to know who you are. Later, I discuss the relative memory of that right, because it is a rescue of what's alive in us - and, no, dead memory - therefore a constitutive element of our identities, follows against modern forms to know about the past. Therefore, I refer to a heterogeneous past vision, that is, not to be confused with the past as the period prior to modernity. Finally, inquire about the possibility of building a living memory of our racial strains that host us.

Keywords: Autoethnography, Coloniality , Race, Family memory, Human rights 


\section{Lista de Quadros}

Quadro 1 - Panorama jurídico sobre a menção da Memória_____ 58

Quadro 2 -Panorama jurídico e histórico da Ditadura Militar no Brasil _____ 61

Quadro 3 -Panorama jurídico e histórico do Genocídio ____ 63 


\title{
Lista de Abreviaturas e Siglas
}

\author{
CA Comissão de Anistia \\ CEAT Comissão Estudantil Anísio Teixeira \\ CEMDP Comissão Especial de Mortos e Desaparecidos Políticos \\ CF Constituição Federal do Brasil \\ CIDH Corte Interamericana de Direitos Humanos \\ CIMI Conselho Indigenista Missionário \\ CPRCG Convenção para Prevenção e a Repressão do Crime de Genocídio \\ CNV Comissão Nacional da Verdade \\ DUDH Declaração Universal dos Direitos Humanos \\ ER Estatuto de Roma \\ FUNAI Fundação Nacional do Índio \\ FARC Forças Armadas Revolucionárias da Colômbia \\ OEA Organização dos Estados da América \\ ONU Organização das Nações Unidas \\ SPI Serviço de Proteção ao Índio
}




\section{Sumário}

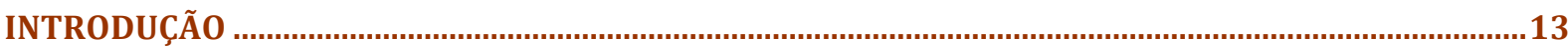

CAPÍTULO 1 - A COLONIALIDADE NA EXPERIÊNCIA VIVIDA …............................................................................17

1.1 A colonialidade do poder

1.2 A colonialidade do saber _ 20

1.3 A colonialidade do ser _ 22

1.4 Raça: o signo da subordinação histórica ___ 23

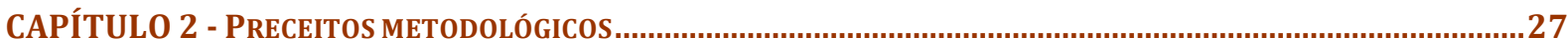

2.1 A diluição da neutralidade da pesquisa ___ 31

2.2 Notas etnográficas _ 33

2.2.1 Minha memória empalidecida __ 34

2.2.1.1 Caminhos contrários: a educação e a consciência racial sobre si ___ 37

2.2.1.2 Por uma educação descolonizada ___ 39

2.2.2 Em busca do elo familiar racial perdido___ 42

2.2.2.1 Gilvan (1940) - A pobreza___ 43

2.2.2.2 Gilton (1954) - 0 patriarcado__ 46

2.2.2.3 Geilda (1949) - 0 racismo familiar __ 47

2.2.2.4 Genilza (1956) - Quando a raça se torna medo e quando você se torna medo devido à raça 49

2.2.3 Desafeto ou negação afetiva? _ـ 51

CAPÍTULO 3 - A CATEGORIA MEMÓRIA NA LINGUAGEM DOS DIREITOS HUMANOS E SUAS FALÊNCIAS........................57

3.1 Panorama jurídico da memória e suas categorias oficiais _

3.20 campo das ausências: Os sujeitos e os tipos de memórias marginalizados__ 65

3.30 jusnaturalismo e o juspositivismo enquanto princípios teóricos basilares de uma linguagem colonial do direito _ 75

3.4 As mazelas da concepção histórica oficialmente contada sobre os direitos humanos __ 79

3.4.1 A ética da insatisfação enquanto princípio fundamental para expansão dos direitos humanos ___ 85

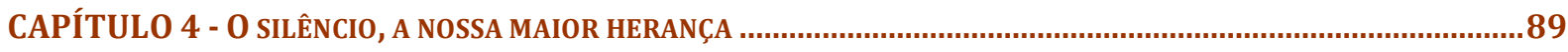

4.1 0 sequestro da maternidade indígena___ 93

4.20 direito humano de saber quem se é _ 95

4.3 Memórias emergentes de um passado presente __ 100

4.3.1 Os contratempos da historiografia __ 104

4.3.2 As contrariedades da museificação ___ 106

4.3.4 A manipulação da memória___ 109

4.4 Em busca de uma memória viva que nos conecte à nossa origem _ 111

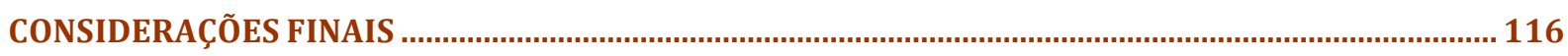

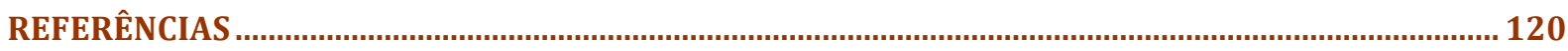




\section{INTRODUÇÃO}

A dor causada por uma falta me moveu até aqui. Mantive firmemente nestas folhas de papel a voz do meu coração e o grito das minhas lágrimas, certa de que estou serrando as correntes coloniais que aprisionam não só a história da minha avó, mas a de inúmeras famílias brasileiras. Concentrei todo o meu pensamento e a minha escrita não no lamento, mas na luta pelo direito humano de saber quem se é.

0 presente trabalho possui como objeto a censura da memória familiar indígena. Essa memória, nomeada ao longo da história do nosso continente como algo inferior, subalterno e vergonhoso, também tem outro nome: Áurea.

Minha avó deixou o seu povo para se casar com um homem branco, meu avô Francisco. Infelizmente não tive a oportunidade de conviver com eles. Quando meu avô faleceu, eu não havia nascido. Já a minha avó morreu quando eu tinha apenas dois anos de idade. Contudo, vi-me, ao longo da minha vida, induzida a conviver com ela de outra forma: meus familiares sempre me lembraram de que levo comigo a sua imagem, já que sou igual a ela.

Dado que o título de órfã de avó e de avô deixou em branco parte da minha identidade, tentei resgatar em meu seio familiar qualquer lembrança relacionada a eles, qualquer informação que concretizasse meu campo de pouso na imensidão da minha descendência afetiva.

Muitas coisas me foram ditas sobre o meu avô e sua família portuguesa, mas quando as deliciosas rodas de conversas atravessaram a fronteira para o lado não branco, havia somente deslembranças. A marca daquela época, inundada de tensões emocionais alusivas à relação inter-racial entre meu avô e minha avó, me pareceu algo tão secreto e doloroso que somente encontrei os rastros dessa presença no lado inconsciente da memória dos meus familiares. Em razão desta falta, a única lembrança que me restou eu encontro todos os dias quando me olho no espelho e vejo em meu rosto o reflexo das curvas descendentes da minha avó.

0 meu afeto pessoal pela minha avó e o meu questionamento para com o esquecimento a que ela ficou condenada na minha família - que sempre privilegiou e acessou as memórias das linhagens do meu avô, descendente de portugueses - emergiu 
como um pergunta política e uma demanda pelo direito à inscrição de sua presença. Logo, este tema me impulsiona à busca de reflexões e referências construtivas para o desenvolvimento não apenas teórico, mas político, sobretudo no que se refere aos possíveis âmbitos e formas de se construir direitos à memória.

Neste sentido, não é somente em homenagem à minha avó Áurea, mas também por conta da minha "insatisfação ética" enquanto brasileira, que venho debater o processo de consciência da nação brasileira com o intuito de desmontar a pedagogia do silêncio de um Estado ideologicamente herdeiro de uma produção histórica racista.

Trata-se de um debate sobre uma ordem racista que se impôs capilarmente no modo de as pessoas construírem suas memórias familiares. Por um lado, como uma decisão interessada das pessoas reeditada cada dia, e, pelo outro, é também uma maneira em que opera um discurso instalado sobre "como é" e "como deve ser" a boa sociedade. São dois processos simultâneos, um retroalimentando o outro. Neste sentido, essa estratégia interessada em esquecer o sangue indígena remete-se ao interesse de acumular "capital racial" (SEGATO, 2007b) e ao seguimento de uma ordem automática já estabilizada no discurso (FOUCAULT, 2012).

Adotei como marco teórico as teorias decoloniais para discorrer sobre a construção histórica da raça a partir da conquista das Américas. Busquei demonstrar inicialmente que com o processo da colonialidade e à medida que este se expande e se consolida nos países da América, as sociedades indígenas que aqui habitam seguem sofrendo intervenções e dilacerações em seus tecidos comunitários. Parte delas encontrou caminhos de continuidade histórica, apesar das pressões exercidas sobre elas, mas muitos de seus membros foram assimilados pela sociedade colonial numa mestiçagem compulsória na qual os componentes indígenas foram capturados e inseridos numa relação subordinada ao europeu (SEGATO, 2005). Devido a este sequestro subjetivo utilizei o termo "resgate" para demonstrar que não se trata de uma reconstrução histórica, mas da possibilidade de acessar um passado interditado.

Logo depois expliquei os caminhos percorridos para a construção deste estudo autoetnográfico e etnográfico familiar. Destaquei a principal via que diz respeito à desconstrução de uma perspectiva hierárquica entre eu (pesquisadora) e os pesquisados (eu e meus familiares), dada a partir da diluição da neutralidade da pesquisa. 
Assinalei que a neutralidade, ao provocar um distanciamento e ao reforçar a polarização pesquisador/pesquisado, atua como uma armadilha edificada por uma estrutura de poder que reproduz, ao afastar as experiências subjetivas e intersubjetivas, uma ordem conteudista colonizadora. Além disso, defendo que o "sentir" (processo que envolve uma interpelação subjetiva/autocrítica) é fundamental para a construção do conhecimento científico. Somente um olhar formatado pela sensibilidade poderá permitir a construção de histórias autônomas.

Posteriormente a essas discussões metodológicas abordei as minhas experiências pessoais e familiares - relativas à minha infância, adolescência e fase adulta - com o objetivo de acusar o sequestro de identidades provenientes do silenciamento sistemático sobre a raça, constatado tanto no espaço familiar quanto educacional e social.

Em seguida, realizei uma busca no âmbito normativo global e regional de direitos humanos a respeito de um direito à memória que garanta a devolução da consciência histórica àqueles que, assim como eu, desconhecem sua origem familiar. Encontrei a menção à memória apenas na Declaração e Programa de Ação de Durban (2001), que a cita como um ato simbólico (discurso honroso) e não como um direito a ser garantido pelo Estado.

A partir desta pesquisa constatei que, atualmente, existem duas categorias oficiais da memória: a da ditadura militar e a do genocídio. Ambas são construídas a partir de reivindicações pessoais e sociais, ou seja, trata-se de um direito à memória que não nasce da lei. Trata-se de uma discussão sobre memórias não positivadas ${ }^{1}$, porém, reconhecidas oficialmente.

Por mais que o direito humano de saber quem se é se enquadre nesse campo de memórias históricas de busca pela verdade sobre nossas origens, não há nenhum documento, tampouco a inserção desta questão como pauta de discussão que acusa o efeito coletivo de esquecimento como um tipo particular de genocídio. Logo, esse direito compõe o que denominei de campo das ausências. Fazem parte deste campo tanto os sujeitos como histórias estigmatizadas como subalternas. Essa marginalização tem como

1 Não existe nenhuma lei que explicitamente fale sobre "o direito à memória da ditadura militar" e sobre o "o direito à memória do genocídio". 0 que existe são marcos históricos sobre esses direitos, como datas comemorativas, programas, criação de órgãos específicos para apurações, decisões legais que reconhecem o direito de se rememorar, entre outras. 
fundamento as ideologias racistas do Estado moderno, responsáveis pelo monopólio da escolha de quais histórias e sujeitos devem fazer parte da história da humanidade.

A inexistência de uma categoria de memória que verse sobre as nossas genealogias raciais mira não só para o esquecimento, mas para uma negação normativa promovida pela linguagem colonial de direitos humanos. Tal linguagem deve-se à relação dicotômica entre as correntes jusnaturalistas e juspositivistas, bem como a construção hegemônica da memória histórica dos direitos humanos. Em contraponto às essas concepções adotei a teoria desenvolvida pela antropóloga Rita Segato sobre "ética da insatisfação" como o principal fundamento para se expandir e incluir no âmbito dos direitos humanos a referida categoria da memória.

A partir de uma perspectiva histórica desde o Brasil inicio a discussão de que o sequestro de nossas memórias resultou em uma nova ordem familiar imposta pela colonização, a qual posteriormente contou com a ajuda de vozes enunciadoras do discurso oficial: da igreja, da política, dos médicos e intelectuais higienistas que, por meio da projeção assimilacionista construíram, no Brasil, a ideia de cenário familiar branqueado, uma vez que somente assim seria possível tornar-se civilizado a ponto de se integrar à modernidade.

A interceptação de memórias, que se inicia com a colonização e se desdobra sob outras formas, retirou dos órfãos de genealogias o direito de saber sobre suas verdadeiras origens e sobre suas verdadeiras histórias. Esse roubo subjetivo naturalizou no inconsciente coletivo uma filiação falsificada de branquitude. A deformação visual de alcance geracional figurou o autêntico, o local, o nacional na cor do Norte: o Brasil se olha no espelho e se vê branco.

Neste sentido almejei frisar ao longo deste trabalho que estamos seguindo passos de uma história de apagamentos e de negações sobre as nossas origens raciais. A falta de consciência sobre quem somos - que dá prosseguimento a uma forma particular de genocídio - está atrelada ao agenciamento seletivo da construção deste tipo de memória. Cabe observar que por esta razão, o estudo sobre a memória apresenta um lugar ambíguo, uma vez que se refere à memória etnográfica familiar e à falta de uma memória no campo de direitos humanos capaz de nos guiar ao encontro de nossas origens censuradas pela matriz da colonialidade que permanece em curso. 


\section{CAPÍTULO 1}

\section{A colonialidade na experiência vivida}

O imaginário do mundo moderno/colonial surgiu da complexa articulação de forças, de vozes escutadas ou apagadas, de memórias compactas ou fraturadas, de histórias contadas de um só lado, que suprimiram outras memórias [...].

Walter Mignolo

Como apontei de forma introdutória, a minha avó, por ser índia, teve sua imagem sequestrada. Ela não fazia parte da minha memória familiar, tampouco da minha memória pessoal - não fazia parte do que sou hoje. Isso porque a minha história familiar teve por muito tempo a voz de um só lado, o branco, representado pela linhagem do meu avô. Foi essa a projeção que todos os meus parentes fizeram sobre si mesmos: de pessoas brancas. Mas o que motivou a construção desses olhares branqueados? Por que eles expurgaram de si mesmos o sangue da minha avó? Por que a nossa história só tinha um lado?

Este tópico não trata apenas do marco teórico, mas de uma conscientização sobre o lado perverso, porém real, da história da colonização nas Américas. Trata-se de um caminho que me fez enxergar a censura como um fator resultante de imposição historicamente branqueada da nação. Qualquer ato impositivo é capaz de criar uma rede de cumplicidade silenciosa entre pessoas, entre Estados ou entre pessoas e o próprio Estado. Os meus parentes foram inconscientemente cúmplices do projeto racista, ainda em curso, da nação brasileira. Aliás, não só eles como todos aqueles que tiveram automaticamente bloqueadas de suas vidas suas linhagens não brancas.

As respostas para essas angústias, travestidas academicamente de inquietações, se voltam para a discussão sobre as dimensões histórico-raciais que carregamos em nosso ser e em nosso olhar. Trata-se de uma percepção sobre as marcas de violências raciais subjetivas que carregamos em nós como um câncer não diagnosticado. Refiro-me ao que foi teoricamente denominado de "colonialidade do ser". 
O debate sobre a "colonialidade do ser" despertou, mas a partir de outras denominações, através dos estudos pós-coloniais. Esses estudos culturais obtiveram destaque por meio de trabalhos sobre o colonialismo norte-europeu na Ásia e na África. Entre os principais autores deste grupo ${ }^{2}$ está o filósofo argentino Enrique Dussel, expoente intelectual da filosofia crítica sobre "o ser e a totalidade histórica" desenvolvida com base na revisão de experiências do antissemitismo, do holocausto judeu, bem como dos povos colonizados (MALDONADO-TORRES, 2007).

O conceito sobre a "colonialidade do ser" foi construído, literalmente desta forma, por outro filósofo argentino chamado Walter Mignolo, um grande pensador sobre geopolítica do conhecimento e transmodernidade. Na América Latina, alguns estudiosos - dentre eles, Mignolo - inspirados pelas teorias pós-coloniais, criaram na década de 1990 um grupo que simbolizou a emergência dos saberes latino-americanos ${ }^{3}$. A teoria de grande destaque, responsável pelos avanços sobre temáticas em torno da colonialidade e da modernidade, foi a da "colonialidade do poder", construída pelo sociólogo peruano Aníbal Quijano.

Mesmo com as enriquecedoras críticas pós-modernas sobre as mazelas da totalidade moderna, a partir da teoria da colonialidade foi possível dar voz às histórias silenciadas, às subjetividades reprimidas, bem como às linguagens e conhecimentos subalternizados pela modernidade/racionalidade. Logo, trata-se de um estudo sobre emergências decoloniais e não pós-coloniais (MIGNOLO, 2010).

Neste sentido, a perspectiva da decolonialidade que se distingue da proposta de descolonização mira para a superação de um padrão de poder que organiza a sociedade, enquanto a segunda se situa no desmantelamento do controle de uma autoridade política (colonialismo/ capitalismo).

A colonialidade do poder (fator econômico e político) possui, além da colonialidade do ser (fator subjetivo), mais um desdobramento: a colonialidade do saber (conhecimento). No tópico a seguir compilarei as ideias principais sobre os referidos conceitos para posteriormente discuti-los.

2 Os autores de grande destaque das teorias pós-coloniais são GayatriSpivak (estudos sobre a subalternidade), Franz Fanon (psicanálise e racismo) e Stuart Hall (identidades pós-coloniais).

3 Entre os principais autores das teorias decolonais estão Aníbal Quijano, Walter Mignolo, Rita Segato, Edgardo Lander, entre outros. 


\subsection{A colonialidade do poder}

A colonialidade do poder refere-se ao modo de produzir e reproduzir conhecimento a partir da perspectiva mundial de padrões de poder: colonial/moderno, capitalista e eurocentrado (QUIJANO, 2005). Este padrão de poder possui quatro eixos fundamentais que serão explicados ao longo deste capítulo. A saber: "a racialização como modelo de classificação social universal", "o direcionamento de toda a forma hegemônica de trabalho e de sua exploração para a produção do capital", "o eurocentrismo como novo modo de produção do conhecimento e de formação de subjetividades" e "o estabelecimento do Estado - Nação como forma de controle e autoridade deste novo padrão de poder, que funcionam inclusive como fiscalizadores e mantenedores do exercício da colonailidade do poder" (FLOR DO NASCIMENTO, 2011, p. 25-35.

A história do capitalismo e da modernidade se inicia com a conquista das Américas. Devido à sua extensão geográfica, o Novo Mundo se tornou um local experimental de exploração e controle de trabalho. A expansão do moderno sistema mundial, desenvolvida ao longo do século XVI, se deu nesse contexto de condições opressivas estruturadas para destruir as populações originárias das Américas (QUIJANO; WALLERSTEIN, 1992).

As formas de controle e de exploração do trabalho, entre elas a escravidão ${ }^{4}$ e a servidão, foram articuladas em torno da relação capital-salário e do mercado mundial, originando uma "estrutura singular de relações de produção": o "capitalismo mundial" (QUIJANO, 2005, p. 228).

O capitalismo - um padrão de dominação e exploração articulado em torno do "capital-trabalho" - foi operado globalmente desde o começo do planeta. Contudo, somente após a constituição desde poder nas Américas que ele se tornou homogêneo em todo o espaço mundial (QUIJANO, 2000).

Neste sentido, pode-se afirmar que a colonialidade do poder se iniciou a partir da criação deste sistema capitalista hierárquico. No topo da pirâmide estavam os europeus,

\footnotetext{
4 Os escravos eram meios de produção de um sistema econômico racista. Mesmo com a "abolição" da escravidão, a raça permanece vinculada a esse sistema.
} 
os quais figuravam como as grandes potências, e na base mais baixa estavam os não europeus, que representavam as colônias. Este sistema perdura nos dias atuais, uma vez que sua reprodução permanece sob outras formas de governo e se traduz em um conjunto de regras de alcance não só social, como político, econômico e cultural (QUIJANO; WALLERSTEIN, 1992).

Portanto, a colonialidade do poder não constituía somente uma subordinação cultural e política, mas um extermínio dos povos indígenas que visava atender às necessidades de expansão capitalista. A respeito, Quijano expõe que:

0 vasto genocídio dos índios nas primeiras décadas da colonização não foi causado principalmente pela violência da conquista, nem pelas enfermidades que os conquistadores trouxeram em seu corpo, mas porque tais índios foram usados como mão de obra descartável, forçados a trabalhar até morrer. (QUIJANO, 2005, p. 229).

Sobre essa sistemática relação histórica cabe explicar as diferenças entre colonialidade e colonialismo. Este último se refere a um sistema político e econômico que precede a colonialidade. O colonialismo é hoje uma relação inexistente nas Américas. A colonialidade, por outro lado, não se restringe a uma relação de poder entre povos e nações, uma vez que se conjugam com formas de dominação e subordinação atreladas, principalmente, às relações intersubjetivas. Ela permanece fazendo parte da nossa experiência de vida (MALDONADO-TORRES, 2007).

A colonialidade do poder apresenta uma estrutura complexa de controle da economia, da autoridade, da natureza e dos recursos naturais, do gênero e sexualidade, da subjetividade e do conhecimento. De acordo com Mignolo (2010), o padrão de poder se sustenta nos seguintes pilares: "conhecer (epistemologia), entender ou compreender (hermenêutica) e sentir (aesthesis)".

\subsection{A colonialidade do saber}

Como mencionado, foi durante o processo de formação do mundo colonial que a Europa foi se definindo como centro hegemônico do mundo. Essa imposição hegemônica se deu, primeiramente, a partir da vitória do centro e do norte europeu contra os rivais 
do Mediterrâneo. Utilizada, então, como uma arma de guerra, se tornou a expressão da centralidade europeia (eurocentrismo) e da colonialidade nas relações do poder (QUIJANO, 2005).

A racionalidade moderna presumia categorias de superioridade e inferioridade construídas a partir das diferenças coloniais e imperiais. A primeira consiste na classificação geográfica e biológica sobre a raça de grupos ou de povos. Ou seja, é fundamentalmente racial. A segunda trata-se de uma diferença articulada pelo imaginário ocidental entre impérios capitalistas, ocidentais e cristãos (MIGNOLO, 2005).

Neste sentido, a forma moderna de produzir conhecimento tem se dado conforme as experiências, as ideias e as práticas sociais capitalistas. Esse modo de produzir conhecimento negou formas de saberes distintos da perspectiva racional moderna, o que impediu os países do Sul de se tornarem lugares ativos de produção de conhecimento. Neste sentido, toda a experiência histórica da América Latina foi designada a um lugar de subalternidade.

Além disso, o desenvolvimento da perspectiva eurocêntrica do conhecimento - e com ela à elaboração teórica da ideia de raça - naturalizou as relações coloniais de dominação entre europeus e não europeus. Historicamente, isso significou uma nova maneira de legitimar as antigas ideias e práticas de relações de superioridade/inferioridade entre dominantes e dominados.

Sobre a colonialidade do saber, vale lembrar que:

- Esta categoria é uma crítica à episteme, ou seja, ao modo de produzir o saber eurocentrado/capitalista.

- A naturalização da inferioridade, no tocante às descobertas mentais e culturais dos povos conquistados e dominados, foram fundamentadas na noção de raça.

- Esta genealogia do saber/poder é um legado presente que motiva a produção de um saber acadêmico apolítico. 


\subsection{A colonialidade do ser}

Este processo relaciona-se à subjetividade que, conforme Quijano (2009), sofreu intervenção dos fatores de classificação e identificação social que se configuraram como instrumentos de exploração permanente. Dessa forma, a dominação colonial implicou, para as populações indígenas e negras, a admissão de uma identidade negativa/colonial.

A subjetividade pode ser definida como um modo de ser - de pensar, de agir, de sonhar, de amar etc. - que delimita o interior e o exterior do ser humano (BORIS; CESIDIO, 2007). Quando a subjetividade sofre intervenções, como a colonialidade, que ocasionou a obstrução, interceptação e cancelamento da memória histórica, dos saberes, das línguas, dos valores, cosmologia entre outras pautas, dos povos colonizados (SEGATO, 2013), ela aniquila a noção "de ser" do sujeito.

A desigualdade entre as identidades europeias e não europeias impediu as populações colonizadas de objetivar suas próprias imagens, símbolos e experiências subjetivas de modo autônomo. Além disso, tiveram que abandonar práticas sagradas ou realizá-las de modo clandestino - e admitir a condição desonrosa de seu próprio imaginário e de seu próprio universo de subjetividade (SEGATO, 2013). Ou seja, além da censura sob o desenvolvimento de qualquer experiência cultural, essas populações foram reprimidas, interferidas e classificadas como subculturas.

Na América do Sul, esse bloqueio teve como principal instrumento dominador a mestiçagem, não só física e cultural, mas a que está sendo abordada: a subjetiva. Por vias de forças, a mestiçagem serviu como estratégia perfeita para o esquecimento de "quem se é", de "onde se veio", do "ser índio" e do "ser negro" (SEGATO, 2010).

Por meio desse modo de assimilação, os povos dominados viram suas formas institucionais desvanecerem, especialmente as referentes à família e às redes de parentesco. As práticas que não foram integralmente esmorecidas sofreram uma readaptação conforme as exigências do padrão global da colonialidade. Sob este contexto, as populações foram submetidas às mais perversas experiências de alienação (SEGATO, 2010).

Diante dessa violenta destruição subjetiva, as comunidades raciais, nacionais, sexuais, entre outras, construíram um imaginário colonial sobre si. 0 termo 
"imaginário", muito debatido pelo autor Édouard Glissante, foi apropriado pelo autor Mignolo, que acrescentou um sentido geopolítico do conhecimento - de fundação e formação do "sistema-mundo moderno" 5 colonial - a este termo.

A teoria do imaginário aponta que a fragmentação de processo de autoidentificação deve-se à "dupla consciência" ${ }^{6}$, compreendida como a manifestação de uma subjetividade forjada a partir da diferença colonial. É dupla por dois aspectos: 1 . porque é herdeira tanto da consciência colonizadora quanto da colonizada (consciência racial), 2. porque a América é ao mesmo tempo ocidental e não ocidental (consciência geopolítica). Essa indefinição sobre um lugar de pertencimento provocou uma confusão sobre quem se é (LANDER, 2005).

Sobre esta teoria é importante notar que o projeto colonial serviu a uma lógica binária onde o "outro" foi estilizado. Não se trata necessariamente da construção de uma falsa imagem, mas de uma redução, uma inferiorização construída a partir do retrato colonizador/colonizado.

\subsection{Raça: o signo da subordinação histórica}

A ideia de raça foi produzida pelo colonialismo no começo da formação da América e do capitalismo na virada do século XV para o XVI. Nos séculos seguintes foi imposta sobre a população mundial como uma classificação social, o que a tornou o instrumento universal mais eficaz do poder mundial capitalista (QUIJANO, 2000). Dessa forma, o eixo raça tem origem e caráter colonial, e provou ser o mais duradouro e estável pilar universal da matriz da colonialidade.

Sob a captura desse olhar, o conceito de raça é trabalhado por Quijano e por outros autores decoloniais ${ }^{7}$ como uma construção mental que expressa a experiência da dominação colonial que permeia importantes dimensões do poder mundial. 0 referido autor destaca que a ideia de raça, em seu sentido moderno, não tem história conhecida

5 Conceito de Wallerstein (2007).

6 Termo utilizado por Du Bois (1999).

7 Como Mignolo, Lander e Segato. 
antes da América. Expõe, ainda, que a ideia sobre a raça não se originou das diferenças fenotípicas entre conquistadores e conquistados, a qual situou uns numa situação natural de inferioridade em relação a outros, pois a raça é anterior a qualquer signo como a cor ${ }^{8}$ e como os traços fenotípicos, que possuem uma conotação racial. Destaca que a primeira raça foi a denominada de "índios" - não há nenhuma referência que indique a associação da categoria "índio" com a sua cor. Logo, a cor é um modo tardio e eufemístico de dizer a raça (QUIJANO, 2000).

Observa-se que por meio da identificação dos signos raciais é possível acessar uma história colonial. Como ensina a antropóloga Rita Segato, a "raça é um signo", ou seja, uma marca que indica a posição histórica do sujeito. Esse código de leitura não é necessariamente o signo de um povo ou de um grupo, mas um traço da história relativo à construção da raça. Por exemplo, a cor negra, o traço indígena, são signos que revelam uma subordinação histórica (SEGATO, 2007b).

A formação de relações sociais fundadas na raça produziu na América identidades sociais historicamente novas - índios, negros e mestiços -, ao mesmo tempo em que redefiniu outras, como exemplo, os termos como "espanhol", "português" (os ibéricos) e mais tarde "europeu", que antes indicavam apenas procedência geográfica ou país de origem e depois passaram a adquirir uma conotação racial (QUIJANO,1993).

0 princípio organizador do trabalho e das relações econômicas foram se construindo mediante essa estrutura racializada. Cada forma de trabalho foi articulada a uma raça particular. Aliás, não só as formas de trabalho, mas as relações sociais configuradas em relações de dominação.

Sendo assim, as identidades foram associadas às hierarquias, aos lugares subordinados aos papéis sociais e ao padrão de dominação que se impunha. Este ordenamento social racista justificava e ainda justifica a violência, a desigualdade econômica e social, bem como as diversas formas de exploração dos povos não europeus. Como ressalta Quijano:

El racismo y el etnicismo fueron inicialmente producidos en América y reproducidos después en el resto del mundo colonizado, como fundamentos de la especificidad de las relaciones de poder entre Europa y las poblaciones del

8 Aníbal Quijano destaca que a cor branca é uma construção de identidade dos dominadores contraposta à cor negra, identidade dos dominados. Mas isto ocorre durante o século XVII, quando a classificação racial já está consolidada e naturalizada (QUIJANO, 2011). 
resto del mundo. Desde hace 500 años, no han dejado de ser los componentes básicos de las relaciones de poder en todo el mundo. (QUIJANO, 1993, p. 14).

A etnicidade é um elemento do colonialismo, baseado em distinções sociais e culturais que delineou fronteiras sociais correspondentes à divisão do trabalho e justificou as formas de exploração do trabalho, como a escravidão dos negros africanos e o trabalho forçado para os indígenas. Mesmo após a independência, as classificações étnicas se mantiveram como formas de controle do trabalho.

Raça e etnia são termos usados de formas distintas ao longo da história. Dois casos justificam essa diferenciação. 0 primeiro se refere a um grupo de estudiosos franceses que utilizou o termo "etnia" para se referir às distintas culturas dentro de uma mesma raça. 0 segundo atribui o termo "etnicidade" ao processo de colonização da América do Norte e da África pela Inglaterra. Durante o período colonização da América do Norte, a relação se deu entre internações. Já a colonização realizada na África constituiu uma relação entre uma nação e diversas tribos (QUIJANO, 1993).

Observa-se que em ambos os casos a palavra etnia é utilizada para marcar as diferenças culturais entre europeu e não europeus. Neste sentido, possuíam etnicidade todos os povos não europeus. Os europeus representavam nações.

Sob esta ótica, vale enfatizar o conteúdo racista inserido no termo etnicidade. A noção sobre etnia não se distingue da noção sobre a raça, muito pelo contrário, ela compõe uma categoria da raça.

O racismo é um elemento constitutivo da colonialidade do poder, esteve e ainda está presente nos modos de vida e nas estruturas de poder como uma ideologia de dominação (como foi o nazismo). Sua configuração não depende de uma ação verbal ou de uma conduta explicitamente racista; ele existe sem que haja uma provocação, visto que se encontra naturalizado na dominação fundada na classificação e na hierarquização de raças.

Alguns países como o Brasil negam a existência do racismo em seus territórios, mesmo este se fazendo presente no âmbito político, social, midiático, pessoal e interpessoal, sob o argumento de que só existe racismo quando verificada uma segregação formal, como a que ocorreu nos Estados Unidos.

A autora Rita Segato, ao discorrer sobre as diferentes concepções sobre a raça e sobre o racismo no Brasil e nos Estados Unidos, aponta que no Brasil a raça possui uma 
marca fenotípica e depende de consentimento, enquanto nos Estados Unidos a raça é compulsória e está vinculada à origem. Em relação ao racismo, a referida autora assinala que no Brasil este se revela "nas relações inter pessoais e sobretudo, intra pessoais". Já nos Estados Unidos se constitui em antagonismos "entre povos percebidos como diferentes e dotados de conteúdo de etnicidade" (SEGATO, 2007b, p. 136).

Entre os tipos de racismo mais praticados no Brasil estão: (1) "o prático", proferido de forma automática, irrefletida e naturalizada e, por isso, não chega a ser reconhecido como tal; (2) "o axiológico", expressado por meio de "predicados negativos ou positivos em função da cor da pessoa"; (3) "o emotivo", exprimido a partir da manifestação de "rancor, ressentimento ou medo em relação a pessoas de outra raça"; e (4) o "político" frequente nos processos de normatização e de regulamentação de políticas voltadas aos setores das populações racialmente marcadas (SEGATO, 2004, p. 3-4).

Neste sentido, nota-se que o racismo pressupõe uma sonoridade colonial que, ao se tornar "natural", se estabeleceu como um modo de relacionamento legítimo, como um modelo de sociedade.

Após estas considerações teóricas pretendo mostrar - a partir de uma fala proveniente de uma experiência familiar- que o sistema moderno colonial habita nossas subjetividades, que o racismo permanece sendo reproduzido na produção de saber cientifico, nas leis e no modo como nos relacionamos socialmente. 


\section{CAPÍTULO 2 \\ Preceitos metodológicos}

As ciências sociais surgiram como uma resposta aos anseios europeus. São produtos do sistema do mundo moderno que se apoiou nas condições histórico-culturais específicas da Europa Ocidental e da América do Norte (WALLERSTEIN, 2007).

Essa construção eurocêntrica que "pensa e organiza a totalidade do tempo e do espaço para toda a humanidade do ponto de vista de sua própria experiência" representa um dispositivo de conhecimento "colonial ${ }^{9}$ e imperial" que denominou as formas científicas, bem como quais seriam os sujeitos de conhecimento. Logo, todo saber e todos os sujeitos estacionados no período anterior ao "desenvolvimento histórico da humanidade" foram classificados como inferiores e primitivos (LANDER, 2005, p. 13).

A referida ciência nasce e se constrói desvendando diferenças sobre os civilizados e os não civilizados. Por essa razão, a análise dos fatos sociais carrega em seu conteúdo a marca da superioridade intelectual como uma estratégia metodológica, uma arma colonizadora de controle sobre os "outros" saberes.

Não só na antropologia, mas em toda a ciência, a razão se tornou o símbolo da autoridade masculina e da raça branca. Os sujeitos de conhecimento não tutelados pela modernidade como mulheres (até mesmo àquelas que viviam na modernidade) ${ }^{10}$ e os sujeitos racializados ficaram à margem deste invólucro científico.

Vale notar que o primeiro marco epistêmico pós-colonial, em contrapartida a esse conhecimento hegemônico, surgiu após a descolonização da Ásia e da África. Esse acontecimento, somado à ascensão de uma consciência política em todos os lugares do mundo, iniciou um contra-ataque ao modelo epistemológico moderno ocidental ao

9 A episteme colonizadora consiste na ignorância e na incapacidade de conceber o outro apenas como objeto.

10 As feministas argumentam que a voz da ciência é masculina e que a história foi escrita desde o ponto de vista dos homens que pertencem à classe ou à raça dominante. A legitimação das mulheres enquanto sujeitos de conhecimento foi muito tardia, e, quando ocorreu, muitas tiveram seus trabalhos investigativos e acadêmicos ignorados, minimizados ou desapropriados (HARDING, 1987). 
questionar a "naturalização das relações sociais" 11 imposta pelo conhecimento científico de caráter objetivo e universal (WALLERSTEIN, 2007). Posteriormente, a América Latina se juntou a este time de contra-ataque. Influenciados pelas teorias pós-coloniais, alguns estudiosos da América Andina se uniram e construíram um marco epistêmico descolonial e decolonial, os quais buscavam formas alternativas "de conhecer". Os questionamentos sobre "o caráter colonial/eurocêntrico dos saberes sociais sobre o continente" se apoiaram nas ideias "da libertação" ${ }^{12}$, no sentido de desnaturalizar "as formas canônicas de aprender-construir-ser no mundo", a pluralidade histórica e epistêmica, perspectivas de resistências e a revisão de métodos (LANDER, 2000, p. 15).

Em harmonia com os diversos e complexos desafios que envolvem o pensar a partir de nós, este trabalho ilustra uma narrativa histórica desde a América Latina, na qual o Brasil é o principal sujeito significativo. Portanto, não é um trabalho que irá reproduzir ideias hegemônicas, tampouco adaptá-las a nossa realidade. Muito pelo contrário, o que se busca são debates que pulsem experiências vividas aqui, no que se refere ao direito humano de saber quem se é. Logo, o ponto central localiza-se na nossa própria contextualização histórica, desde o Sul. Afinal, que tipo de cientistas seríamos se desconhecêssemos nossa própria história?

A aposta nas nossas próprias dinâmicas históricas - e, também, políticas - aponta para a discussão sobre a relação do pesquisador para com o sujeito de estudado. Como delineado, o pesquisador das ciências sociais era o antropólogo, o europeu, o civilizado e o objeto era o povo primitivo e selvagem. Nesse campo científico havia uma nítida separação entre o sujeito e o objeto do conhecimento, a qual se articulava metodologicamente a partir da distância empírica (SOUZA SANTOS, 1987).

0 processo de distanciamento empírico tinha como fundamentos a distinção entre humano e não humano. Este simbolizava tanto a natureza quanto os povos de sociedades vistas como primitivas (SOUZA SANTOS, 1987). A desumanização do "outro" 13 objeto desumanizou a relação entre o pesquisador e os pesquisados.

Neste sentido, os estudos etnográficos foram se construindo sob a perspectiva hierárquica, na qual o sujeito do conhecimento estava sempre no topo e o sujeito

11 Termo utilizado por Lander (2000).

12 Referente tanto à filosofia da libertação de Enrique Dussel quanto à teoria da libertação de Paulo Freire.

13 O termo "o outro" está sempre precedido de aspas porque sua construção se remete à redução identitária como se esta fosse estática, imóvel e fixa. 
pesquisado sempre na base. Esses estudos, além de androcêntricos, eram sexistas, racistas e impediam, durante o desenrolar do exercício etnográfico, a elaboração de uma relação intersubjetiva do pesquisador para com o pesquisado.

Além disso, não era comum a prática de autoquestionamento face às experiências de campo, pois não havia identificação do pesquisador para com o local, a cultura, tampouco com o sujeito da pesquisa ${ }^{14}$. A ausência de questionamentos subjetivos acabava reforçando o mito "do antropólogo neutro" (GROSSI, 1992). E não somente isso: quando o exercício etnográfico se encontra preso a essas armadilhas da imparcialidade, dificilmente há interpelações para além da racionalidade que sejam capazes de alcançar as "problemáticas do poder", como o colonialismo e suas bases racistas e sexistas. Logo, existe um grande risco de o pesquisador reproduzir, principalmente durante a escrita, uma ordem conteudista colonizadora.

Por essa razão, pensar na relação entre pesquisador e sujeitos da pesquisa (e não objetos de pesquisa) requer a construção de uma relação humana entre ambas as partes. Não seria uma relação apenas "com o outro", mas "como o outro". Essa condição de alteridade é fundamental para humanizar a relação entre pesquisador/pesquisado, bem como para alertar sobre as armadilhas do poder científico.

Em síntese, a produção de conhecimento exige do pesquisador não somente o ato de raciocinar, mas uma sensibilidade capaz de mudar o seu olhar sobre as suas próprias perspectivas e de provocar um sentimento de afetividade para com a temática da pesquisa a ponto de torná-lo um analfabeto de uma ciência colonizadora e um alfabetizado de uma ciência emancipadora.

A escrita deste trabalho foi motivada por um sentimento de dor causado pela falta da memória da minha avó enquanto mulher e índia. Ao me reconhecer em sua imagem, ao me identificar com suas heranças raciais, pude refletir e construir o conhecimento que trago para debate. Logo, é possível construir conhecimento tendo por motivação sentimentos de dor e de angústia15.

Neste sentido, a etnografia se coloca como importante mecanismo de apreciação de significações humanas, pois permite o exercício de interpelações subjetivas e

\footnotetext{
14 Sobre esta questão vale destacar que as antropólogas pós-década de 1960 que realizaram pesquisas sobre a crise da identidade feminina refletiram quando foram a campo sobre a sua própria identidade. Havia uma relação não só de antropóloga, mas de mulher perante as outras mulheres pesquisadas. (GROSSI, 1992).

15 Georges Devereux, fundador da Etnopsiquiatria (1971).
} 
intersubjetivas. Essas trocas cedem espaço para que o pesquisador compreenda, em profundidade, as diversas visões e realidades, sem cair na malha da certeza de padrões e conclusões definitivas.

O exercício etnográfico está atrelado à subjetividade. Dessa forma, emana de um "olhar formado pela história individual do pesquisador", ou seja, se consubstancia a partir de uma "experiência marcada pela biografia individual de cada pesquisador" (GROSSI, 1992, p. 9). O autoconhecimento é também conhecimento, uma vez que motiva a construção de histórias autônomas.

A finalidade desta pesquisa etnográfica é de obter a partir da observação, da troca, da experiência, um corpo de ideias transformador produzido por vozes e também pelo silêncio de lembranças que sirvam como reflexão sobre a importância de se pensar e resgatar memórias familiares raciais.

Para tanto, a técnica da etnografia foi desmembrada em autoetnografia e etnografia familiar, a fim de mobilizar lembranças afetivas que conduzam à autorreflexão e a intrarreflexão de referenciais raciais. Tanto uma quanto a outra se fundamentam no incômodo comunicável e nomeado, bem como no incomunicável, na falta. As duas técnicas foram desenvolvidas a partir de um mergulho nos atos cognitivos. Primeiro eu senti a dor e a angústia causada por uma censura. Posteriormente a essa identificação, eu a observei, a ouvi e a escrevi.

Como demonstra Oliveira (1996), o exercício etnográfico não é feito somente de observação. 0 olhar, por si só é insuficiente. Para alcançar os significados das relações sociais é necessário ouvir e escrever. No entanto, quando o pesquisador assume uma posição neutra ele detém atos de poder que desempenham "uma função profundamente empobrecedora do ato cognitivo". Por exemplo, no caso das entrevistas, os questionamentos realizados pelo pesquisador correm o risco de girarem em torno de "respostas pontuais lado a lado da autoridade de quem as faz - com ou sem autoritarismo - criam um campo ilusório de interação". Ou seja, não haveria uma relação “dialógica” (OLIVEIRA, 1996, p. 24).

A relação dialógica faz com que "os horizontes semânticos em confronto abramse um ao outro, de maneira a transformar tal confronto em um verdadeiro encontro etnográfico". Trata-se de um diálogo horizontal entre pesquisador e pesquisado, o qual refuta "a neutralidade idealizada pelos defensores da objetividade absoluta" (OLIVEIRA, 
1996, p. 24). Essa relação de mão dupla envolve a observação participante, na qual o pesquisador busca interpretar, compreender e agir com os sujeitos pesquisados.

A observação participante é definida como uma "participação real do pesquisador na vida da comunidade, da organização ou do grupo em que é realizada a pesquisa"; é uma técnica introduzida pela antropologia na qual se chega "ao conhecimento da vida de um grupo a partir de seu próprio interior". É muito utilizada em pesquisas que envolvem o estudo de grupos tradicionais (GIL, 2009, p. 74).

Existem duas formas de observação participante: a natural, relativa ao pesquisador que pertence à mesma comunidade ou grupo de investigação, e a artificial, quando há a integração a um grupo (GIL, 2009).

Diante dessas considerações teóricas, pode-se dizer a realização etnográfica familiar me colocou na posição de participante natural, uma vez que a pesquisa foi realizada no meu âmbito familiar. 0 compartilhamento de vivências familiares, de sentimentos comuns e incomuns desconstruíram a linha imaginária de uma interação vertical. Além disso, por não se tratar de um exercício intelectual de foco estritamente acadêmico sobre "o outro" e também sobre mim mesma, as etnografias copilaram atos de sensibilidade e honestidade em momentos de desobstrução emocional.

\subsection{A diluição da neutralidade da pesquisa}

Para muitos teóricos influenciados pelo método rigoroso das ciências naturais ${ }^{16}$, o pesquisador deveria estudar os fatos sociais do mundo como elementos exteriores e abstratos que separam o estudo científico da realidade social. Entretanto, segundo Creswell (2007), na pesquisa, o eu pessoal torna-se inseparável do eu pesquisador. Ou seja, não existe um pesquisador desinteressado da sua própria pesquisa, visto que o interesse ocorre tanto de forma objetiva quanto subjetiva.

16 Como explica Boaventura, a ciência moderna nasce com a revolução científica em meados do século XVI. Esta forma de produção de conhecimento baseava-se na linguagem matemática em que "conhecer significa quantificar" e "o que não é quantificável é cientificamente irrelevante". 0 período de gestações científicas foi se constituindo de acordo com este modelo de racionalidade "global e totalitário", o qual "negava o caráter racional de todas as formas de conhecimento que não se pautassem em seus princípios e regras epistemológicas” (SOUZA SANTOS, 1987, p. 11-15). 
Grossi, ao instigar a problematização da subjetividade na prática antropológica como um modo de diminuir o distanciamento entre o pesquisador e o sujeito da pesquisado, adverte para urgência da "revalorização da experiência subjetiva" fundada na autoconsciência e na autocrítica (GROSSI, 1992, p. 10). 0 que o referido autor denominou de "mergulho na subjetividade" foi por muito tempo compreendido no meio acadêmico ora como "indiscrição", ora como "autoexposição ridícula". Muitos dos trabalhos que apresentavam em seu teor relatos sobre as experiências pessoais do pesquisador ficaram restritos à literatura. Logo, não eram considerados trabalhos científicos.

A minha relação com o objeto de pesquisa, qual seja, a falta de uma memória, foi se construindo no decorrer da minha vida. Logo, trata-se de uma relação anterior à pesquisa. Nesta construção estiveram presentes aspectos subjetivos que exigiram de mim mesma muita atenção para os dilemas entre o meu eu (pesquisadora), o meu eu (sujeito pesquisado por mim) e o meu eu (integrante familiar).

A minha auto-observação, que inclui a observação etnográfica familiar, por diversas vezes desconstruiu e construiu minha performance como pesquisadora. Eu me vi inserida em uma dinâmica cuja constituição sobre mim mesma se dava a partir do encontro com os meus parentes participantes da pesquisa. Quando eu estava com eles estas três posições se fundiam.

A saber, a minha posição como pesquisadora estava mais presente no ato da escrita quando eu tive que cientificizar a minha experiência de vida. A maior preocupação nesta caminhada foi de encontrar brechas na escrita que evitassem a materialização das falas e dos sentimentos que deram vida a este trabalho. Encontrei na autocrítica a sincronia, a qual permitira a produção de uma escrita vívida.

Então, produzir conhecimento a partir da minha experiência de vida, de uma experiência familiar, refutou as complexas relações de poder, bem como evitou a neutralização das relações interpessoais as quais darei voz não de um modo singular, mas plural e horizontal. 


\subsection{Notas etnográficas}

Tanto a autoetnografia quanto a etnografia familiar vêm sendo realizadas desde a minha infância. Trata-se de um conjunto de observações que relatam experiências pessoais e familiares sobre raça, afetividades proibidas e, portanto, negadas. Envolvem relatos pulsionais, confissões, preceitos éticos que visam proporcionar a reflexão sobre quem somos.

As temporalidades da autoetnografia transitam entre a minha infância, adolescência e fase adulta. Neste contexto, destaco dois espaços, o familiar e o educacional, como cruciais para a (de)formação da minha identidade. As temporalidades da etnografia familiar referem-se ao passado vivido por mim e pelos meus parentes. São relatos de experiências que exprimem possíveis mecanismos de aniquilação da memória racial. Tais relatos se dão tanto em um tempo em comum - vivido por mim e por meus familiares - como em um tempo singular - a minha narrativa fora do âmbito familiar e as narrativas dos meus parentes relativas às suas infâncias e juventudes.

Esse conjunto de experiências está atrelado aos diversos momentos do passado: o meu passado, o passado dos meus parentes e o nosso passado. Por esse motivo, as narrativas oscilaram livremente entre todas as temporalidades sem que se fixasse um fio condutor cronológico.

A primeira vez que me deparei com a raça foi no âmbito familiar. Eu tinha seis anos de idade quando escutei meus familiares me estereotipando. Logo, o olhar sobre mim, a observação do meu eu, foi provocada pelo olhar do "outro". Foi este o marco que me fez enxergar a minha cor e os meus signos raciais.

No que se refere à educação, a experiência foi contrária. Nunca tinha escutado nada sobre raça na infância. Somente na faixa dos dezesseis anos - período de preparação para o vestibular - escutei dos meus professores do ensino médio incentivos para me candidatar às cotas raciais da Universidade de Brasília (UnB). Contudo, não foram inferidas reflexões sobre "o que era" o sistema de cotas. Havia apenas uma orientação de que era mais fácil passar no vestibular por meio deste sistema, o que na verdade é um grande mito, muito utilizado para desqualificar o sistema e para discriminar os cotistas. 
Neste sentido, a autoetnografia e a etnografia familiar serão trabalhadas não só como técnicas de pesquisa, mas como um mecanismo capaz de primeiramente acusar o silenciamento sistemático sobre raça - e, consequentemente, sobre as nossas linhagens não brancas -, bem como buscar novos sentidos e novos olhares sobre quem se é.

\subsubsection{Minha memória empalidecida}

Nasci em Brasília. Sou filha de Gilton, nordestino, pernambucano, e de Anna Cláudia, brasiliense como eu. Por parte de pai tenho duas heranças familiares: uma indígena e uma portuguesa. A primeira foi encobertada por muitos anos como um segredo que deveria ser guardado a sete chaves, não por ser precioso, mas por ser vergonhoso. A segunda sempre esteve disponível. Era e é sinônimo de orgulho para toda família. É sobre a história do silenciamento a respeito de minha linhagem indígena que venho apresentar esta nota etnográfica.

Após os seis anos de idade as minhas vozes interiores, abafadas em certo grau na minha infância, nunca deixaram um dia sequer de me revelar diante do espelho a luz dos meus signos tensionados e reforçados no meu seio familiar por meio de nomeações como "sua indiazinha" e por vezes "sua neguinha", pronunciadas pelos meus parentes como um palavrão. Velada no suposto sentimento de carinho por estarem no diminutivo, elas apresentavam em suas entrelinhas um tom de indignação por eu não ter nascido branca suficientemente a ponto de me igualar ao resto da família.

Toda vez que um dos meus familiares ressaltava as minhas diferenças se abria uma fresta no meu imaginário, capaz de ouvir uma voz interior gritar que eu não pertencia àquela família. Estranha! Adotada! Ter um irmão branco agravou este cenário. Apesar de ele apresentar signos indígenas assim como os meus, sua raça era associada à japonesa devido à sua cor.

Diante desse contexto uma grande confusão se instalou no meu ser, na minha mente, no meu coração, pois eu os via como mais claros do que eu, mas não como diferentes de mim. Eu conseguia enxergar uma grande semelhança entre todos nós, já que grande parte da família, incluindo meus parentes, possuía traços indígenas. 
A insistente associação do meu irmão à raça japonesa indicava a tentativa de esconder nosso sangue indígena e de glorificar o sangue branco. 0 que representava um paradoxo, visto que ao mesmo tempo em que eles tentavam ocultar a diferença atribuindo aos signos do meu irmão características de brancura, eles apontavam a diferença ao se referirem a mim.

Neste momento me dei conta de que apenas não tinha nascido conforme os ideais de branqueamento da minha família (incluo todos os parentes). Os olhos azuis do meu avô e sua pele de cor clara não convenceram o destino de que meu pai, descendente de um homem branco, e minha mãe, a mulher branqueada ${ }^{17}$ com quem se casou, tivesse uma filha branca, aos olhos da sociedade brasileira.

Entre todos os meus parentes, eu sou a mais parecida com a minha avó. Hoje compreendo que isso foi causa de grande fúria familiar, visto que nasci com signos que desafiaram a tentativa de ocultação da linhagem indígena.

Descobri que tinha uma avó índia quando a cunhada do meu pai, que morava em Garanhuns - PE, estava de passagem em Brasília e resolveu nos visitar. Era domingo, eu e meu irmão estávamos na sala assistindo à televisão enquanto esperávamos a nossa tia. A tia Maria nos acolhia nas férias de dezembro em sua casa quando por lá passávamos a caminho das belas praias do nordeste. A atual casa dela era a antiga casa onde meus avós moraram e criaram seus 14 filhos, sendo 13 frutos do casamento e uma filha negra $\operatorname{adotiva}^{18 .}$

Nesta tarde, ao chegar, ela segurou a minha mão me observou atentamente e disse alegremente para o meu pai: como ela cresceu e ficou a cara da Áurea! Meu pai balançou a cabeça positivamente. Sem caber em mim de tanta curiosidade lhe pedi uma foto e ela me respondeu que não sabia se tinha, mas que iria procurar. No primeiro momento, seu comentário me causou espanto, era inconcebível a dúvida sobre ter ou não uma foto da minha avó, ainda mais pelo fato de minha tia ainda estar morando na casa que era da minha avó.

Somente seis anos após este diálogo, quando eu já tinha completado 27 anos de idade, consegui finalmente ver pela primeira vez uma fotografia da minha avó, e não foi a tia Maria que me mostrou. Para que eu conseguisse ver a foto, pedir não foi o

\footnotetext{
17 Utilizo o termo branqueado para me referir às pessoas que nasceram com a cor branca mesmo sem ter uma linhagem 100\% europeia.

18 Sem registros de adoção.
} 
suficiente. Apesar do acesso à foto ser um direito meu, tive que convencer todos os meus tios de que merecia ver a foto.

Como em um trabalho de formiguinha, fui explicando, à medida que ocorriam os encontros familiares, os motivos pelos quais eu gostaria de acessar tudo que pertencia ou que se referia a minha avó. Todos ficaram cientes de que o meu principal motivo era este trabalho de dissertação. Expliquei também sobre a importância e urgência em se discutir sobre a censura das linhagens não brancas no Brasil e, logo, meu argumento se tornou válido. Na verdade, o motivo que preponderava sempre foi o de resgatar a avó índia que nunca tive e, assim, resgatar a minha história e a minha identidade.

Na minha família a censura se desenvolveu em uma atmosfera de segredo que se deu por meio de uma colaboração silenciosa. Não se chegou a criar uma história falsa sobre a origem da minha avó, mas, por vezes, era notável tanto a ocultação quanto a negação da história.

Todas as observações realizadas no meu seio familiar notificaram-me sobre o quanto a família acaba se tornando o principal centro de referência sobre nós mesmos. Ela é capaz de ordenar o lugar de seus membros dentro dela. 0 meu lugar não era o mesmo dos meus primos branqueados.

Contudo, mesmo que essa ordenação pareça um caminho natural, cada um é responsavelmente portador de uma chave decisória sobre o seu próprio lugar familiar e social. Alguns optam por jogar suas chaves fora; escondem, guardam ou substituem por outras chaves dadas por suas famílias. Sendo assim, acabam deixando de atravessar a porta que vai ao encontro de quem se é. Desconhecem que esta é a única porta que proporcionará uma consciência sobre si mesmo e que não se abrirá se a chave não for a verdadeira.

Deixei com que todas as chaves entregues a mim pela minha família se enferrujassem a ponto de se tornarem inutilizáveis. Elas não eram as chaves certas que iriam abrir a minha porta. A que abriu a minha porta foi deixada pela minha avó. Mesmo sem saber sobre muita coisa relativa a ela, sinto-me apta para realizar esta travessia. Hoje posso dizer que o meu lugar sincero, afetivo e real eu acesso todos os dias quando olho no espelho e desfruto do encontro de "Áureas". 


\subsubsection{Caminhos contrários: a educação e a consciência racial sobre si}

A única referência que eu tinha sobre "o que é ser índio" devia-se ao estudo dos povos indígenas como inferiores e não civilizados que, pedagogicamente, eram reduzidos a um só povo. Além disso, era notório o descaso com todas as pluralidades linguísticas, religiosas e culturais. Esta visão educacional reducionista também apresentava uma entrada alienante a respeito das organizações sociais e políticas de cada povo - fato que adensava o desprovimento da concepção "de ser" destes.

Todas estas narrativas do "ser índio" folclorizado eram repassadas pela minha professora sem qualquer tom de crítica como se: a) existisse apenas um povo indígena no país e uma só língua, a portuguesa; b) como se meus traços fenotípicos fossem invisíveis; c) como se não houvesse descendentes indígenas no Brasil; d) como se nosso sangue fosse completamente branco; e) como se nenhum de nós tivesse qualquer elo com os povos indígenas. De tal maneira, foi um ensinamento colonizador de como sufocar qualquer tipo identificação e afeto para com esses povos.

Na época da universidade ${ }^{19}$ o que me chamou muito a atenção foi o incentivo dos professores em cultivar o orgulho branco através da valorização dos sobrenomes estrangeiros dos colegas no ato da chamada. Lembro-me perfeitamente de que todos os meus colegas, que assim como eu possuíam sobrenomes abrasileirados, ficavam plenamente constrangidos porque ter um sobrenome comum passava a mensagem de que sua linhagem não era nobre.

Essa ideia propagada pelos professores atribuiu aos colegas que carregavam a brancura do nome o status de mais interessantes, influentes, inteligentes e ricos. Nas rodas de amizade essa cultura se tornou um diferencial para a escolha das amizades profissionais, como se o sobrenome carregasse sucesso.

Nesta época eu já fazia uma leitura de mim mesma como mulher não branca e o meu sobrenome reforçou esta imagem. Contudo, eu ainda não sabia me definir, principalmente quando me deparava com documentos que perguntavam sobre a minha cor. Diante de um claro problema de identidade, passei a não declarar a minha cor nos

19 Refiro-me à minha graduação em Direito no Centro Universitário de Brasília (UniCeub). 
formulários que a requisitavam. Quando a declaração era obrigatória (me refiro a algumas exigências médicas), eu me declarava negra.

Algumas pessoas me aconselharam a tomar como parâmetro os critérios do Censo. 0 Censo é um sistema constituído por perguntas objetivas e não abertas, logo, ele não permite ter dúvidas sobre a identidade. Sendo as cores atribuídas às características étnicas e raciais construções históricas, como o Censo poderia desconsiderar esta questão, incluindo-a em critérios classificatórios residuais sem que houvesse a discussão desta perspectiva?

Além disso, pensar neste sistema requer a clareza de que nem todas as categorias de cor estiveram disponíveis ao longo da história do Censo. Por exemplo, a categoria pardo (1872) surgiu antes da indígena (1991), fazendo com que muitos indígenas se declarassem pardos (SCHWARCZ, 2013) apesar de serem categorias diferentes.

Adotar os critérios do Censo como uma solução para definir a identidade demanda reflexão. 0 problema desses critérios transpassa a discussão sobre a metodologia empírica de modo a alcançar o questionamento de como o Censo lida com a raça, tendo em vista que esta não é apenas um dado, um produto, mas um processo de significação. Contudo, cabe destacar que apesar destas questões o Censo é um instrumento relevante, pois funciona como o principal legitimador das políticas afirmativas.

Como relatei, a raça nunca esteve presente nas conversas familiares ou nos debates escolares. Não havia um espaço reflexivo capaz de me orientar na construção da minha identidade, ainda quando criança. Mesmo depois que me descobri como não branca, não vislumbrei meios possíveis para compartilhar esta experiência. Ao me redor só havia reprodutores de ideias. Os professores repetiam o conteúdo dos livros, distantes da minha, da nossa realidade. A minha família reproduzia o que tinha aprendido na escola, bem como as ideias de branqueamento enraizadas na sociedade.

Antes de percorrer os caminhos que discutem sobre os mecanismos de aniquilação da memória aportados na etnografia familiar, abrirei este debate sobre censura, educação e raça com a exposição de algumas notas. 


\subsubsection{Por uma educação descolonizada}

No ensino fundamental, nos anos de 1990, estudei "personagens" de uma história romântica: o negro e a escravidão, o índio e a selvageria, os portugueses e a civilização. Contudo, essas histórias não eram acompanhadas de discussões sobre cor e raça. Na verdade, em todas as disciplinas predominava o silenciamento sobre a raça.

A figura do índio se reduzia a um folclore, o qual pode ser visto tanto como a reprodução de nossas heranças culturais como uma forma de aprisionamento ${ }^{20}$ destas heranças. Reduzir a figura do índio aos repertórios de criações culturais é uma forma de negar a continuidade dos povos indígenas, bem como de camuflar a origem indígena.

Essa política escolar autorizada pelo Estado, que mantinha o índio distante de nós, aplicava a colonialidade do saber racista e excludente que, como visto, é um dos pilares da colonialidade do poder. Logo, essa educação colonizadora, fundada na ideologia racista que privilegiava a brancura, não era uma característica só da minha escola, mas de todas as escolas do Brasil. Aponto para a colonização tanto do currículo quanto do ensino escolar.

No campo dessas indagações, o Movimento Negro, com o intuito de diminuir a discriminação racial enraizada justamente pela corrupção dos saberes culturais étnicoraciais nas escolas, elaborou um projeto de resolução sobre "Diretrizes Curriculares Nacionais para a Educação das Relações Étnico-Raciais e para o Ensino de História e Cultura Afro-Brasileira e Africana", que felizmente foi aprovado por unanimidade pelo Conselho Nacional de Educação no ano de 2004 (BRASIL, 2004). Sem dúvida, este marco firmou uma conquista que simbolizou, em princípio, o rompimento com o monopólio educacional discriminador.

No ano de 2008 foi promulgada a Lei nº 11.645/2008 (BRASIL, 2008), que alterou a Lei no 9.394/1996. 0 motivo da alteração deve-se à necessidade de inclusão da história, cultura e identidades indígenas não contempladas na lei anterior. Verifica-se a partir dessa lei que o estudo da cultura afro-brasileira e dos povos indígenas brasileiros tornou-se obrigatório na educação básica (ensino infantil, ensino médio e fundamental).

200 folclore brasileiro foi influenciado pelas teorias racistas de autores como Nina Rodrigues e Sílvio Romero. 
Para que a referida lei se torne eficaz, as escolas precisam contemplar um pacote mínimo que envolve: adquirir materiais didáticos condizentes com a proposta e retirar de suas listas de materiais obras literárias que reforçam o racismo; investir na formação crítica dos professores e no delineamento das propostas metodológicas para abordagem do conteúdo. Sobre esta questão, em 2009 foi lançado o "Plano Nacional de Implementação das Diretrizes Curriculares Nacionais para Educação das Relações Étnico-raciais e para o Ensino de História e Cultura Afro-brasileira e Africana"(BRASIL, 2009). Este documento pedagógico expõe em seu texto as ações primordiais a serem executadas, quais instituições são responsáveis por elas e em quanto tempo elas devem ser elaboradas. A execução desse plano ainda está em curso. Até o presente momento não foram disponibilizados relatórios sobre os impactos desta valiosa tentativa de reparação educacional.

Essas diretrizes curriculares de resgate de identidades, histórias, culturas e saberes foram sem dúvida um passo muito importante para a defesa da diversidade e do combate ao racismo, tanto o institucionalizado quanto o proferido entre os alunos e entre professores e alunos.

Cabe ressalvar que tais diretrizes possuem como objetivo principal a heterogeneização da educação a partir da inserção de estudos sobre a cultura afro e indígena. Todavia, aponto para emergência de não só expor o conteúdo, mas de trabalhá-lo em sala de aula de maneira que, tanto os alunos quanto os professores, alcancem de forma dialógica o sentimento de afetividade étnico e racial. Deve-se atentar para o risco de cooptação da forma de trabalhar esses conteúdos.

A adoção de uma metodologia expositiva manteria a neutralidade tanto dos alunos quanto dos professores para com esses estudos, bem como o transformaria em um conhecimento técnico, sem que houvesse um comprometimento de trocas interpessoais e sociais capazes de suscitarem a transformação social e a emancipação humana. Para isso, o conteúdo não deve ser dado, mas construído junto com os alunos. Caso contrário, cairá no círculo da mera absolvição e reprodução de conteúdos.

Não basta deixar de produzir (des)conhecimentos (como fez a minha professora ao falar sobre os povos indígenas), é preciso produzi-lo de forma consciente. Paulo Freire (1969) ensina que a educação não é uma repetição de lições memorizadas, mas sim, um diálogo criativo, uma reflexão solidária, um desafio a pensar e não a memorizar. Envolve uma atividade crítica e não dogmática e autoritária, que exige do "educador- 
educando" uma reconstrução permanente do ato de conhecer por meio da problematização do conteúdo.

0 desafio de descolonizar ${ }^{21}$ o conhecimento envolve não só a inclusão de conteúdo, mas a revisão sobre as práticas metodológicas. É indispensável o resgate, dentro da história, de tudo aquilo que nos caracteriza. Sem esse resgate, além de permanecermos distantes do que somos, nossos corpos seguirão como objetos essencializados, ou, como denomina Foucault (2012), "subjetificados" pelos discursos de poder. Ou seja, todas as nossas diferenças permanecerão apagadas da história (da nação) e da nossa história. A educação tem que ser o espelho da nossa realidade.

Por essa razão, aponto para a importância do resgate, no âmbito escolar, de sentimentos de valorização, de afetividade e de orgulho não branco a partir da inovação nos métodos de ensino que capacitam os alunos para o processo de consciência de si mesmo, no que se refere às questões de raça. Não se perder nos discursos da supremacia branca é um modo de ressignificar nossas histórias de vida, mas para isso precisamos primeiramente construir uma relação de afeto.

Essa relação afetuosa possui duas vias: (1) a que permite a construção da identidade e da personalidade do aluno quando ele, ao se enxergar como semelhante ao índio ou ao negro, percebe que isto é motivo de orgulho e não de vergonha; (2) a que promove a aproximação entre as crianças. Estas irão se aproximar quando perceberem que suas diferenças não são algo nem inferior nem superior, mas natural. Para isso, os professores precisam abandonar o discurso de que todos os alunos são iguais, de modo a valorizar a diversidade dentro de sala de aula.

Até os meus seis anos de idade eu só me via como uma criança (sem cor e signos raciais aparentes), pois toda a turma era tratada como branca. Tratar todos como iguais era uma forma de a professora manter a turma integrada. Caso as minhas diferenças e a de outros colegas tivessem sido ressaltadas, seríamos tratados como estranhos, seríamos motivos de gozações e ofensas. Como não éramos nem suficientemente negros nem indígenas para a nossa escola, passamos sem muitas dificuldades pelo filtro do branqueamento.

21 Para discorrer sobre o processo de descolonização recorri às teorias da feminista dominicana Ochy Curiel (2010). Neste sentido, o verbo "descolonizar" utilizado aqui envolve não só o reconhecimento histórico, econômico, político e cultural dos povos da América latina, mas a luta por autonomia frente aos processos culturais e políticos que têm sido produto do capitalismo, a modernidade ocidental e a colonização europeia. 
A falta de diferenciação fragmentou nossas identidades. Crescemos incorporando o branco. Construímos uma série de preconceitos contra nós mesmos que nem sequer desconfiávamos que fossem preconceitos. Temos em mãos o grande desafio de cessar este silenciamento na sala de aula. Caso contrário, permaneceremos reforçando essa estrutura racista que abarca conteúdos (revisão dos currículos escolares), metodologias (construções críticas, debates, arte-educação) e relações entre professor-aluno, alunoprofessor e entre alunos.

\subsubsection{Em busca do elo familiar racial perdido}

A etnografia familiar é um elemento essencial para o desenrolar de cenários autônomos, além de um precioso instrumento de alcance da identificação. Neste trabalho, ela é desenvolvida a partir de um conjunto de observações relacionadas aos traços fenotípicos dos meus parentes, às conversas individuais e coletivas, comportamentos, lembranças, esquecimentos e omissões que se constituirão ao longo deste trabalho em fontes escritas narradas por mim.

Não foram realizadas entrevistas, uma vez que estas poderiam promover uma relação de poder entre o entrevistador e o entrevistado. Além disso, quando essas relações são estabelecidas, a observação é pensada fora da história particular e as experiências de vida se tornam classificáveis. A etnografia, pelo contrário, promove a sensibilidade e a abertura para que a relação seja horizontal.

Além da observação, documentos, tais como fotos e certidões - por não possuírem sentidos isolados - servirão como acompanhamento do passado vivido pelos narradores: meu pai Gilton e meus tios Gilvan, Geilda e Genilza. Cabe destacar que minha avó teve com o meu avô treze filhos, dos quais seis estão mortos, quatro aceitaram contribuir para este trabalho e três optaram por não participar.

Verifica-se que as narrativas referem-se a dois homens e duas mulheres de diferentes idades, porém todos com mais 60 anos. Apesar de serem membros da minha própria família, o consentimento foi solicitado a todos os mencionados, os quais aceitaram revelar e compartilhar publicamente seus sentimentos e experiências de vida. 
Dessa forma, a reflexão que pretendo promover é que quando existe a censura da referência de onde se veio, dificilmente se sabe quem se é. Não saber quem se é provoca consequências avassaladoras tanto para o indivíduo e sua família quanto para a sociedade. Como exemplo, nota-se o crescimento das práticas de racismo e de endorracismo (racismo contra si mesmo).

É importante notar que a noção de família definida neste trabalho refere-se a um grupo de pessoas ligadas consanguineamente. Contudo, o resgate dessa linhagem bloqueada possui tanto uma proposição sanguínea quanto afetiva, sendo que a primeira dependente da segunda. 0 sangue só será reconhecido e valorizado quando houver afetividade para com a história que aquele sangue traz consigo.

Apesar de a minha análise ter sido iniciada na infância por meio da escuta e, posteriormente, da observação e comparação física com os outros membros da minha família, tive que ir muito além da avaliação fenotípica para alcançar a verdade histórica. Ou seja, considerei os aspectos biológicos, mas o mergulho tomou fôlego na consciência sobre a minha formação genealógica.

Ao realizar este mergulho me deparei com a seguinte inquietação: em que circunstância um grupo familiar que possui os mesmos laços biológicos pôde perder, na história de suas vidas, a compreensão sobre o significado de uma parte de sua genealogia? Essa pergunta provoca outra: por que, no Brasil, grande parte das famílias não fala sobre a raça de suas linhagens?

Os relatos das observações a seguir atuarão como um feixe de luz em busca de uma resposta que gira em torno de possíveis mecanismos de aniquilação da memória indígena, ou seja, da memória racial.

\subsubsection{Gilvan (1940) - A pobreza}

Quando o meu avô morreu, meu pai e meus tios tiveram outra cor de infância. Uma cor que representava o medo e a dor. Eles ainda moravam em Garanhuns - PE, que naquela época era uma cidade pequena quase esquecida e não oferecia muitas oportunidades. Minha avó não trabalhava e o cansaço da idade já havia lhe tomado. Diante da impossibilidade de serem sustentados por sua própria mãe, seus filhos, 
mesmos aqueles que ainda eram crianças, se encarregaram de garantir a sobrevivência de toda família. Eram jornadas não reguladas por leis, trabalhos insalubres que retiraram por desgastantes anos o tempo de "ser criança".

A sensação de desamparo causada pela morte desavisada do meu avô, que sustentava a casa através do salário que recebia como protético, lançou um grande desafio ao meu pai e aos meus tios: buscar meios dignos para sobreviverem.

A rigidez com a qual a minha avó criava os seus filhos aumentara a cada dia. Se fosse preciso eles apanhariam com a corda de nós todos os dias, mas de modo algum se perderiam no mundo das drogas presente nas ruas de Garanhuns. Insistentemente, minha avó ensinava que a educação era o único meio de se lutar contra a pobreza.

Sem a ajuda da família rica e aculturada por parte do meu avô ${ }^{22}$, cada um se virou do jeito que podia. A escola localizava-se a seis quilômetros de casa e o percurso era a pé, mesmo se a barriga estivesse vazia. Não tinham dinheiro para pagar transporte, muito menos para ter um carro. Depois da escola eles trabalhavam até o entardecer e quando lhe restavam forças eles recorriam aos livros pela madrugada. Colocavam seus pés em bacias de água gelada para se manterem acordados.

Assim foi, de forma simplória e reduzida, a rotina do meu pai e dos meus tios. Esse cenário mudou timidamente quando meu tio Gilvan, o filho mais velho, concluiu os estudos e decidiu servir ao Exército de Recife. Foi quando eles adquiriram uma condição de vida relativamente melhor e as sopas de pedras, por vezes, eram substituídas por bacalhau.

Gilvan serviu ao exército em Recife até 1961, quando voltou para Garanhuns. Sem muitas perspectivas de trabalho, se lembrou de uma vez ter escutado de um namorado branco da sua irmã que Brasília estava cheia de oportunidades. Quando ele decidiu vir para Brasília sua irmã já havia se casado e estava morando com seu marido em uma casa no Guará. Ele ficou lá por um tempo. Trabalhava de dia e estudava à noite até que se tornou funcionário público, construiu sua própria casa, se casou e decidiu trazer os seus irmãos para que também estudassem na capital do país. À medida que um melhorava de vida, outro irmão era trazido e aos poucos todos foram felizmente construindo suas vidas em Brasília.

22 O dia da partilha da herança do meu bisavô português foi a última vez em que toda a família se reuniu. Nada foi cedido para família "bastarda", que fazia jus a este nome por causa da raça da minha avó. Além disso, foi pedido para que eles cessassem qualquer contato com a família nobre de Recife. 
Diante desta história de vida em que o ponto central era a sobrevivência, como a raça poderia ocupar suas vidas de maneira sobressalente? Apesar de sentirem as dores causadas pela raça, a dor da fome era singularmente pior.

Mas esta miséria era miséria porque tinha cor. Tinha uma "marca colonial" 23. Se meu avô tivesse se casado com uma mulher branca, como queria a família dele, ele não teria sido execrado do seu seio familiar. Logo, desfrutaria dos mesmos privilégios de suas irmãs e estes se estenderiam automaticamente aos seus filhos, frutos de um relacionamento que manteve a pureza do sangue branco ${ }^{24}$ na família. Portanto, dignos de pertencerem à família.

Contudo, meu avô foi contra os discursos de sua corrente familiar. Apaixonou-se por uma linda índia e casou-se com ela. Foi acusado de levar o sangue impuro para família e por esta razão foi deserdado tanto materialmente como afetivamente. Esta situação de desamparo alcançou todos os membros da família que ele havia constituído com a minha avó.

A sua condição de vida, a busca incessante pela sobrevivência econômica, a segregação e discriminação familiar, foram a porta de entrada para a construção de sentimentos de inferioridade que os induziram a aniquilara memória racial, a memória da minha avó. Aniquilar a raça era uma forma de esquecer tudo que ela causou.

Vale mencionar que a pobreza - que vai além das questões materiais, uma vez que é também um acúmulo de questões subjetivas - provoca a aniquilação das memórias raciais justamente por apresentar estratos sociais coloniais que invadem as dinâmicas familiares.

23 Termo utilizado por Rita Segato (2007a).

24 Sobre esta questão vale destacar a perspectiva da colonização interna na Europa. Portugal tinha uma relação de subalternidade no que diz respeito à dependência econômica. A sua formação nacional tem um histórico de miscigenação. Os portugueses já eram mestiços antes de chegarem ao Brasil. Neste sentido, a associação da ideia de pureza e superioridade racial à figura do português são formulações não do Norte, mas pelo Sul, devido a essencialização do Europeu. O autor Boaventura na tentativa de localizar Portugal no Sul e construir a imagem do português enquanto um colonizador próspero discute sobre esta questão no artigo "Entre próspero e Caliban: colonialismo, pós-colonialismo e interidentidade". 


\subsubsection{Gilton (1954) - 0 patriarcado}

Das poucas vezes que meu pai que se referiu a minha avó, o nome dela aparecia precedido por "dona". Não era somente ele que a chamava assim, o seu irmão mais velho e sua irmã caçula também. 0 som de "dona" certamente se apresentava como um distanciamento afetivo, uma tradução oposta ao de mãe. Ao indagar o meu pai sobre o significado de dona, ele me respondeu que tinha uma conotação de respeito.

A corda com nós que minha avó carregava em seu pescoço, a severidade direcionada aos seus treze filhos para que eles não se perdessem em mundos negativos, fragmentou a construção de uma relação familiar inteiramente afetuosa. 0 respeito se sobressaia à figura materna. Não digo, pois, que não havia afeto, mas que este afeto se escondia atrás da linguagem do respeito.

A falta de uma postura passiva mantenedora de uma ordem patriarcal na figura da minha avó foi um dos motivos responsáveis pela naturalização do distanciamento afetivo no seio familiar. Ela era uma mãe superprotetora, mas da forma que aprendera com a sua mãe índia.

Após muitas reflexões compreendi que o emprego de "dona", na verdade, era a manifestação assombrosa de que a minha avó não se enquadrava no ideal de mãe. A figura materna que ela desempenhava perante os seus filhos fugia do modelo institucional familiar de representação. A memória corporal que ela carregava e reproduzia em seu lar desconstruía a imagem de mãe subordinada, de mãe cívica, o que expulsava a brancura da mãe boa.

A adoção da linguagem "dona" teria se estabelecido devido a um olhar patriarcal de seus filhos sobre a figura de sua mãe? Sabe-se que a ordem patriarcal apresenta dimensões simbólicas e representativas que não necessariamente, para se tornar legítima, deve ser proferida por um homem pátrio.

De acordo com a referida experiência familiar, verifiquei que essa não foi a única causa do bloqueio afetivo. Além do olhar patriarcal dos filhos sob a figura de sua mãe, verifiquei que o fato de minha avó ter tomado para si a posição de mãe "autoritária" dizia: não permito que vocês me acessem.

A completa troca de afetividade permitiria com que seus filhos estabelecessem uma conexão com o seu outro mundo, o indígena, o qual ela havia abdicado 
parcialmente. 0 seu aprisionamento entre os dois mundos, o branco e o indígena, talvez tenha sido o principal motivo para a imposição dos limites afetivos que impediram a transmissão de experiências e sentimentos. O fato de ela impedir, mesmo que inconscientemente, seus filhos de acessarem o mundo indígena, foi uma maneira de branqueá-los.

Portanto, quando o processo de trocas afetivas familiares sofre um bloqueio, as memórias tendem a ser silenciadas no momento da construção da própria subjetividade.

\subsubsection{Geilda (1949) - 0 racismo familiar}

Em uma tarde de verão ensolarada no ano de 2014 fui acompanhada do meu pai visitar a minha tia chamada Geilda. Não era apenas o calor proporcionado pelo sol, mas calor da esperança de que finalmente eu iria ver uma foto da minha avó.

Contente em nos receber, minha tia me abraçou, me beijou e foi até a cozinha passar o café e preparar a tapioca. Sem muitas delongas ela segurou a minha mão e disse: você quer saber sobre a sua avó, não é? Acredito ter falhado em esconder a minha ansiedade por vezes crônica e respondi que sim.

Ela foi em direção ao pequeno e estreito corredor de seu apartamento e entrou em um dos quartos. Voltou com um álbum de capa desbotada de uma paisagem montanhosa que tinha em seu centro um grande lago. 0 álbum tinha laterais de cor marrom remendadas com linhas, como se tivesse sido recuperado de um tempo mal cuidado. No meio das fotos pretas e brancas estavam três fotos da minha avó, duas em que ela está sozinha e outra em que ela está com família do meu avô, todas tiradas depois de casada.

A maioria das fotos do álbum, que tinha em torno de 60 fotos, era da família portuguesa. Não havia nenhuma foto dos meus bisavós por parte de pai. Além disso, um fato curioso chamou minha atenção ao observar a foto em que Áurea aparece com toda a família portuguesa: as cores das roupas. A família portuguesa usava roupas brancas e a 
minha avó, meu avô e seus filhos roupas listradas de cor cinza - uma clara materialização da segregação da parte "pura" e da parte "não pura" da família25.

Perguntei para a minha tia se podia ficar por alguns instantes em seu quarto e amavelmente ela afirmou que sim. Ao sentar na cama, fiquei por alguns minutos sozinha tentando entender todos os sentimentos que vieram à tona. Ao observar a foto, vi e revi a minha avó em mim. Ao mesmo tempo em que eu ia sendo preenchida de emoções ternas, me deparava com o vazio de lembranças. Não cheguei a conhecê-la e poucas coisas sobre ela me foram contadas.

Durante esse processo de identificação senti um orgulho imenso por ser parecida com aquela mulher de pulso forte que, ao mesmo tempo, era sensível e solidária. Queria sentir que fazia parte daquela história, mas eu não tinha memórias. Aliás, eu ainda não tinha percebido que os meus signos raciais eram as melhores memórias que eu poderia ter da minha avó.

Voltei à sala onde estavam meu pai e minha tia. Perguntei a eles se sabiam sobre o paradeiro das suas tias portuguesas e eles afirmaram que não, mas relataram um caso.

Quando Geilda, Gilton e Gilvan estavam de passeio a Recife, com o carro que notavelmente vinha do interior devido à marca no para-brisa da fusão da poeira com a garoa, eles decidiram parar para visitar uma de suas tias. Com lágrimas nos olhos eles relataram que foram recebidos rapidamente em uma de suas varandas. Aquela varanda que fica junto à porta de entrada no térreo. Nunca chegaram a conhecer o interior de nenhuma das casas de seus tios. Sentiam que eram tratados como "bichos".

Toda a carga emocional manifestada estava atrelada ao sentimento de não poder pertencer à própria família, de ocupar um lugar racializado, determinado pelos próprios tios que estavam ali representando a figura do colonizador.

Sob esse prisma, a segregação racial familiar foi um dos fatores que aniquilou a memória racial da minha avó. Aniquilou-se para não se sujeitar novamente à inferiorização da raça que, desta vez, corria o risco de ser proferida por um de seus descendentes.

\footnotetext{
${ }^{25}$ Essa foto compõe a dedicatória desta dissertação.
} 
2.2.2.4 Genilza (1956) - Quando a raça se torna medo e quando você se torna medo devido à raça

Em uma das férias de fim de ano para o nordeste em que eu e minha família viajamos com a tia Genilza, seu marido branco e minhas duas primas brancas para Porto Seguro - BA, paramos para visitar uma feira de artesanato dos índios pataxós, localizada na praia de coroa vermelha. Lá, minha tia escutou de uma índia que estava vendendo colares: "você não nega a raça com essa cara de bolocha".

Quando presenciei esse episódio estava a caminho da adolescência, o que me impediu de avaliar a complexidade daquele momento. Naquela época a minha percepção pelo ocorrido se restringiu à notificação de um sentimento de vergonha que aquela índia pataxó fez minha tia passar na feira. No primeiro momento julguei a reação dela como algo desproporcional, uma revolta sem motivações. Eu já fazia uma leitura de não brancura sobre mim e, ao me colocar no lugar dela, sabia que não me sentiria ofendida. Contudo, eu desconhecia todas as suas experiências de vida atreladas à questão racial.

Um tempo depois, já adulta, devido a algumas incitações provocadas em mim pela própria vida - que despertou o que eu realmente era - e após desvendar os relatos de discriminação racial no âmbito familiar, constatei que o sentimento de vergonha estampado no rosto da minha tia se opunha ao meu julgamento simplista.

A reação dela não foi apenas um susto acrescido de vergonha. Na verdade foi muito mais do que isso, foi uma tradução do medo. Ela tinha medo das palavras que estabeleciam um vínculo, uma identificação, um elo simbólico com a raça de sua mãe, e por isso renegou sua afeição indígena.

Para ela, as palavras soaram primeiramente como uma acusação não só por terem sido proferidas por uma indígena, mas por esta ter violado o seu status de turista no momento em que foi confundida com os nativos (indígenas). Essa dicotomia nativa/turista apresentou-se como um bloqueio que a impediu de reconhecer, através do "outro", a si mesma.

O sentimento afetivo sobre suas origens não foram reavivados na consciência da minha tia, pois, primeiro, ela não queria ser descoberta como tal - apesar de seus signos indígenas serem notórios. Segundo, ela não queria que sua família a redescobrisse como tal. Ela já havia se casado com homem branco e suas filhas nasceram brancas. 
Como nessa época, nem eu, nem meu irmão, nem minhas primas sabíamos que a nossa avó era indígena, interpretei que a "acusação" da pataxó como um grito de verdade que não poderia ser escutado por nenhum de nós.

A tentativa da indígena de insinuar um vínculo racial para com a minha tia se traduziu numa experiência de coerção. A máscara da inverdade foi ferozmente arrancada do rosto da minha tia, na rua, em público, o que colocou o sentimento de vergonha cara a cara com a verdade de modo a acionar o medo.

0 referido medo emergiu por meio de vozes que invocaram momentos de dor vividos por ela na sua infância, os quais ecoavam a discriminação familiar que ela e seus irmãos haviam sofrido. Essa discriminação era devida ao fato de seu pai, filho de português, ao se casar com uma índia, ter deixado como herança signos que os classificavam como não membros familiares de uma família que se considerava hegemonicamente branca.

Aquela sensação de ir para a casa de seus tios (filhos de portugueses) e não poder entrar sequer no lar, visto que eram recebidos sempre na varanda da porta principal como estranhos à família; a dor de ter trabalhado ainda quando criança para ajudar no sustento da casa enquanto os primos do outro lado da família usufruíam da educação fora do Brasil, entre outras vivências, vieram à tona.

0 que parecia vergonha, na verdade, era encobrimento da dor. Neste sentido, afirmo que a dor é um dos mecanismos de aniquilação da memória. Minha tia não queria que suas filhas sentissem a dor que ela sentiu. Então, tentou apagar primeiro cognitivamente qualquer informação que a vinculasse à raça de sua mãe. Acreditou que ao ocultar as origens da minha avó, bem como as lembranças de segregação e discriminação familiar proferida pela família branca, iria conservar o amor das suas filhas para como ela.

Um dos escudos contra a dor era o silêncio. Não revelar para que a discriminação não seja reproduzida. Observei que a dor reestruturou sua subjetividade de modo a convencê-la a se tornar e a construir uma família branqueada.

Toda essa complexidade do medo de sentir dor era devida ao peso de carregar a raça. No dia da "acusação" minha tia não estava preparada para aceitar a verdade sobre "quem era", não estava preparada para se tornar herdeira desta história racial, pois isso ativaria a dor de um ciclo discriminatório vivenciado desde a sua infância e que eu desconhecia até a escrita deste trabalho. 


\subsubsection{Desafeto ou negação afetiva?}

A minha dúvida desde o início da escrita deste trabalho residia sobre o fato da imagem racial da minha avó ter sido aniquilada no meu seio familiar por motivos de desafeto ou de negação afetiva. A partir da etnografia familiar foi possível não só observar, mas ouvir os diferentes silêncios que caminhavam em direção à distorção e, consequentemente, ao apagamento de si mesmo.

As vivências familiares somadas às conversas atualizadas com o meu pai e com os meus tios relataram a existência de um grande sentimento afetivo deles para com a minha avó índia. Longe de atuarem como ditadores dos próprios corpos, sem medo de que fossem julgados por mim, meus parentes externaram a dor e a angústia 26 acompanhadas pelo complexo amor pela minha avó. Contagiada por estas emoções, mesmo sem compreendê-las em sua totalidade, já que todo este aparato emotivo envolvia diversas questões singulares - e por vezes intocáveis - entre cada um dos filhos com a sua mãe, tentei, ao observar os rostos, as vozes e as histórias, entender o significado do silêncio em comum.

Em suas recordações, como em qualquer outra, havia lembranças boas e ruins. Vigiei que a boa fluía sem pausas. Já a ruim entristecia o olhar, detinha uma postura cabisbaixa e confundia as boas recordações. Era por vezes silenciosa e causava uma estranha intimidade com a figura materna.

Este cenário projetava, à imagem da minha avó, ambivalências: a mãe boa e a mãe má. Esta estava sempre atrelada a alguns atos da minha avó ligados à sua raça. Sua rigidez, sua braveza e seus violentos modos de educar aprendidos com a minha bisavó, reforçavam no seio familiar suas raízes. A discussão com os meus parentes sempre colocava em voga que "Áurea era ríspida, tinha um grande coração, mas era bruta com a gente". Já o seu avô Francisco "era amável e flexível, ele salvava a gente das surras da sua avó". "Era um homem bom". "Veio de uma família muito bem educada".

26 Como lembram Fanon, (2008, p. 137), “toda angústia provém de certa insegurança subjetiva ligada à ausência da mãe". 
Os hábitos de Áurea eram duplamente esgotantes para os seus filhos. Primeiro porque eram visto como agressões, e segundo porque, para eles, significava a reprodução de uma memória étnica - o seu modo de educar era igual ao do seu povo27.

Ao inverter os papéis, notei que o incômodo se agarrava firmemente no segundo motivo, pois se meu avô surrasse seus filhos, ainda sim continuaria sendo o pai que educou corretamente.

O orgulho incomensurável do meu pai e dos meus tios de terem um pai branco filho de português foi o suficiente para não proporcionar a ambivalência relativa à figura do pai, que sempre foi de "pai bom" por estar acompanhada dos atributos de brancura.

Neste sentido, pode-se dizer que a raça e os atributos que ela carrega são fatores determinantes da intensidade afetiva entre os membros familiares, seja entre pais e filhos ou entre irmãos. Meus parentes concentraram seus laços afetivos na figura do meu avô (tudo que ele representava por ser branco), a tal ponto de negar a nossa memória indígena.

À luz destes quadros, construiu-se uma figura da minha avó como a mãe que havia proporcionado, através de sua herança racial, a dor. Não se parecer com aquele de quem se tem orgulho e ainda carregar consigo os olhos puxados, o nariz esparramado e toda a rispidez emocional, provocaram embaraçosos sentimentos nos meus tios detentores da aparência indígena.

A evidência desta incomodidade vinha de berço. Desde quando eram bebês suas características físicas eram desvalorizadas mediante a comparação com os outros irmãos de olhos claros, pele branca e nariz fino, os quais eram vistos por toda família como os mais bonitos por serem semelhantes ao meu avô.

No meu seio familiar sempre estiveram presentes estas regras identitárias que são a reprodução de uma ordem social. Apesar de aparentemente inocentes, elas são uma forma de violência que "internaliza compulsoriamente e brutalmente" o que se deveria ser ou parecer ser. Ela atinge, sobretudo, os "sujeitos branqueados, considerados não-negros, na sociedade brasileira" (SOUZA,1983; SEGAT0, 2006b, p.17).

Neusa Souza, ao discorrer sobre "repulsão fenotípica", explica que esta se constrói "às expensas dos atributos físicos não brancos" e são carregadas como uma

\footnotetext{
27 A associação da raça a uma criação agressiva foi feita pelos meus familiares. A respeito, vale enfatizar que este modo de educar é na verdade o espelho do modelo de criação branco.
} 
"ferida". Uma ferida "do corpo que se transforma em ferida do pensamento", o qual impede o sujeito de representar sua real identidade (SOUZA, 1983, p. 7-10).

A ferida se fortalece na falta de uma "estrutura psíquica harmoniosa" com o corpo. Quando a imagem que o sujeito tem de si é baseada na dor ou no desprazer, o corpo obriga-lhe a esquecê-la. 0 sujeito cria uma relação de estranhamento com o corpo, momento em que ocorre a fragmentação da construção identitária (SOUZA, 1983, p. 6).

0 rompimento dos laços afetivos vinculados à raça provocou outro questionamento no tocante à consciência desta manifestação. Seria a negação afetiva racial um ato consciente ou inconsciente dos meus familiares? Por mais que minha reflexão vá ao encontro de dois caminhos estruturalmente diferentes e complexos, em ambos é possível notar a presença de uma colonização subjetiva.

Durante a escrita deste trabalho contemplei que o sentimento de inferioridade enquanto uma memória corporal se atrelava à presença dos signos indígenas. Caso o sentimento de inferioridade tivesse uma ligação apenas genealógica e se todos os meus tios tivessem nascido brancos, devido à possibilidade de se esconder atrás da brancura, o referido sentimento não se somaria à dor.

A dor maior não está em saber a verdade sobre o sangue indígena, mas na impossibilidade de omitir veementemente a raça sob o olhar do outro que julga, oprime, humilha, desclassifica e despeja em você o peso da raça. Este cenário se torna ainda mais negativo quando o outro é um membro da sua própria família, carrega o mesmo sangue, não é menos branco que você, mas o desclassifica como se branco fosse.

Quando há aceitação desse julgamento branqueado, mesmo sendo ele a fiel representação de uma imposição histórica violenta e autoritária, há a negação. A pessoa aceita porque ela sabe que não é branca, mas prontamente nega o estigma na tentativa de esconder "de si próprio" a verdade. Por conseguinte, negar a própria raça é aceitar a colonização dentro de si.

De modo hipotético, seria o meu caso se posteriormente ao conhecimento sobre a minha linhagem indígena, eu a negasse. A principal motivação de negar estaria no fato de aceitar o estigma da vergonha sobre esta raça, construído pelos colonizadores e reproduzido socialmente nos dias atuais.

Ao esconder a verdade sobre "quem se é" as pessoas se tornam utopicamente livres para se enquadrarem no modelo identitário branco, como se a ocultação facilitasse essa transição. Casos como estes são ainda mais comuns quando um dos membros 
familiares descobre uma linhagem branca na família. Por mais que este membro não seja branco, ele vai se agarrar, valorizar e se enclausurar nesta branquitude enquanto uma salvação identitária.

Ao invés de se aceitar como inteiramente não branca, esta pessoa recorrerá aos diversos caminhos alternativos utilizados como formas de se equiparar à brancura, uma vez que enxerga como uma única janela a do mundo branco. Dessa forma, procedimentos físicos de branqueamento como afilar o nariz e alisar o cabelo, a própria formatação familiar branca e heterossexual (a título de exemplo, todos os meus tios e tias se casaram com pessoas brancas ou branqueadas), a ostentação de coisas materiais que possuem um status social branco como roupas e carros, o desenvolvimento de uma mentalidade branca que discrimina tanto social quanto academicamente, bem como outras formas que alimentam esta dependência do branco, a qual obedece a um “complexo de autoridade" 28 e de hierarquização de raças.

Neste sentido, parte "do ser" - simbolizado pela adoção subjetiva de atitudes brancas - e "do ter" "tenta alcançar o santuário branco", pois ser branco é ser "rico, bonito e inteligente", é ser superior, é ser herói (FANON, 2008, p.60).

A falta de afetividade em virtude da raça não caracteriza uma amnésia afetiva, uma vez que ela é reversível, ainda mais quando se trata de um fato inconsciente. Foi este caminho do inconsciente - sinônimo de uma colonização automática e de uma assimilação - que se tornou memória de nossos corpos que vislumbrei durante o exercício da etnografia familiar.

Portanto, trata-se de uma memória assimilada pelo corpo. Nela, as formas de alcançar a brancura são realizadas roboticamente. De que forma? Quando o racismo, o estereótipo negativo, a discriminação e os preconceitos são incorporados às estruturas sociais. À medida que estes movimentos ocorrem, todos esses violentos trajetos direcionados à valorização da brancura vão se naturalizando na sociedade.

Como um chip ${ }^{29}$ implantado em nós, em nossas mentes e sentimentos. Como se fôssemos um pen drive novo esperando a transferência de arquivos. Como um retrato de uma completa alienação psíquica passível de múltiplas consequências.

28 O termo complexo de autoridade é utilizado por Frantz Fanon (2008) em sua magnífica obra Pele Negra, Máscaras Brancas.

29 Termo utilizado por Rita Segato (2006a) na obra Antropologia e Direitos Humanos: alteridade e ética no movimento de expansão dos direitos universais. 
Sob este prisma, o foco do problema está em saber se é possível às pessoas não brancas superar o seu sentimento de inferioridade próximo ao comportamento fóbico. Como explica Fanon (2008, p. 137), a fobia é a presença latente da falta ou da deformação do afeto. 0 fóbico obedece às "leis da pré-lógica afetiva”.

Estudos psicanalíticos demonstraram que a fobia está aliada ao ódio. Como o amor, o ódio tem que ser cultivado a todo instante para que exista. 0 ódio não é algo dado. É algo que se torna ódio. Como já dizia Nelson Mandela, para odiar as pessoas é necessário aprender. À luz desse pensamento, as pessoas foram ensinadas a odiar o diferente, o que não faz parte do mundo branco.

Neste sentido, cabe enfatizar a tarefa de identificar quando o ódio se torna ódio. 0 mesmo raciocínio se aplica à noção de vergonha: quem ensinou aos meus parentes que ter sangue indígena era vergonhoso? Ora, a vergonha não nasceu com eles.

Vale dizer que as famílias são grandes redes de transmissão e de conservação da memória, mas nem toda memória que está sendo repassada representa a bagagem histórica construída por aquele grupo familiar. Ela pode ser oriunda de uma construção histórica moderna/colonial socialmente compartilhada.

No meu caso familiar, é nítida a distorção desta bagagem. Houve a implantação neural de uma memória branqueada no consciente dos meus familiares que os levaram a aniquilar a nossa memória racial. Sem que estivesse presente a dúvida e o questionamento se seguiu reproduzindo uma memória ideológica que anulou memórias de vida.

A partir destes debates vale destacar que o ápice desta pesquisa reside na afirmação de que o complexo de inferioridade, onde se localiza a vergonha, faz parte do inconsciente não só da minha família, mas da sociedade. A respeito, explica a psicóloga e ativista do Movimento de Mulheres Negras, Maria Lúcia da Silva:

Ao internalizar atributos negativos, que lhe são imputados, instala-se o sentimento de inferioridade, causando constrangimento na relação com seus pares, e favorecendo o aparecimento de comportamentos de isolamento, entendidos, freqüentemente, como timidez ou agressividade. 0 racismo atua negativamente na esfera intrapsíquica, afetando o eu e comprometendo sua identidade. Essa ocorrência se deve às repetidas experiências de desvalorização da auto-imagem, difundidas tanto pelas instituições como pelas relações interpessoais, e à interiorização do eu ideal europeu, branco. (SILVA, 2005, p. 3). 
A sociedade tornou possível o complexo de inferioridade ao afirmar, de todas as formas e em todos os espaços, a superioridade da raça branca. As pessoas não brancas foram colocadas diante do "dilema de branquear ou desaparecer" (FANON, 2008, p. 95). Esta foi a grande trama construtora do complexo de inferioridade.

O legado traumático está inteiramente ligado ao legado racial colonial. Os sentimentos de vergonha, de inferioridade, de repulsão, negação e endorracismo ${ }^{30}$ são marcas que se apropriam das nossas subjetividades.

Sob este contexto, os signos raciais se tornaram transmissões traumáticas. Estes, ao evidenciarem a "marca de uma história de dominação colonial" e ao impedir, mesmo que nos tornemos branqueados, que sejamos reconhecidos como brancos - ainda que tenhamos "dois avôs e duas avós européias", nos obriga a carregarmos conosco "uma paisagem histórica de não brancura". E quando "viajamos para o Norte imperial não importa se sua cor é branca, negra, amarela, marrom escura ou clara”, todos nós somos classificados como não brancos (SEGATO, 2010, p. 19).

Diante desse prisma, para que não haja uma sujeição completa ao racismo, é necessário conscientizar o inconsciente "a não mais tentar um embranquecimento alucinatório, mas sim a agir no sentido de uma mudança das estruturas sociais" e subjetivas (FANON, 2008, p. 95). Os autores apontam para a emergência de uma conscientização que desperta "uma nova possibilidade de existir" guiada pela valorização de si mesmo e não do “outro branco" (FANON, 2008, p. 96).

Como expõe Souza (1983, p. 17), "uma das formas de exercer autonomia é possuir um discurso sobre si mesmo". A construção da identidade se dá mediante o reconhecimento de tudo aquilo que se crê próprio. Para tanto, se faz significativo o conhecimento da verdade sobre quem somos. Isso só é possível por meio do resgate das nossas memórias familiares.

Em virtude desta dor acompanhada de uma insatisfação ética apoiei-me nos direitos humanos - afinal, saber quem se é consiste num direito humano - com o intuito de encontrar um direito à memória que garantisse a devolução da consciência histórica àqueles que, assim como eu, desconhecem sua origem familiar.

30 Termo utilizado por Rita Segato (2007b) na obra La nacíon y sus otros. 


\section{CAPÍTULO 3}

\section{A categoria memória na linguagem dos direitos humanos e suas falências}

\subsection{Panorama Jurídico da memória e suas categorias oficiais}

O propósito deste capítulo é, em primeiro plano, afirmar que a memória é um direito humano que possui um vasto campo de categorias. Entretanto, apenas dois tipos de memória são oficialmente reconhecidos pela comunidade normativa de direitos humanos: a memória da ditadura militar e a do genocídio.

A comunidade jurídica de direitos humanos à qual me refiro relaciona-se tanto com o âmbito normativo global, Organização das Nações Unidas (ONU), quanto regional de direitos humanos. Contudo, vale ressaltar que a realização da pesquisa relativa ao âmbito regional - composto pelo sistema americano, africano e asiático - se restringe ao primeiro sistema, ou seja, às principais normas internacionais de direitos humanos da Organização dos Estados da América (OEA).

Para averiguar a menção da memória enquanto categoria de Direitos Humanos realizei uma análise documental, na qual pesquisei em doze documentos oficiais - nove globais (ONU) e três regionais (OEA) - a palavra "memória": a Declaração Universal de Direitos Humanos (1948), a Declaração sobre a Concessão da Independência dos Países e Povos Coloniais (1960), a Convenção Internacional sobre a eliminação de todas as formas de Discriminação Racial (1965), o Pacto Internacional de Direitos Civis e Políticos (1966), o Pacto Internacional sobre os Direitos Econômicos, Sociais e Culturais (1966), a Declaração sobre Raça e os Preconceitos Raciais (1978), a Convenção 169 sobre Povos Indígenas e Tribais (1989), a Declaração sobre os Direitos das pessoas pertencentes a minorias nacionais ou étnicas, religiosas e linguísticas (1992), a Declaração e Programa de Durban, bem como a Convenção Americana de Direitos Humanos (1969), a Convenção Interamericana contra o Racismo e toda forma de 
Discriminação e Intolerância (2013) e a Convenção Interamericana contra o Racismo, a

Discriminação Racial e Formas correlatas de Intolerância (2013).

Quadro 1 -Panorama jurídico sobre a menção da Memória

\begin{tabular}{|c|c|c|c|c|}
\hline Documentos Legais & Âmbito & Promulgação & Brasil signatário & $\begin{array}{l}\text { Menção à } \\
\text { memória }\end{array}$ \\
\hline $\begin{array}{l}\text { Declaração Universal dos } \\
\text { Direitos Humanos. }\end{array}$ & Global & ONU-1948 & $\begin{array}{lr}\begin{array}{l}\text { Sim, em } 1968 . \\
\text { Sem } \\
\text { vinculante. }\end{array} \\
\end{array}$ & Não \\
\hline $\begin{array}{l}\text { Declaração sobre a Concessão } \\
\text { da Independência dos Países } \\
\text { e Povos Coloniais. }\end{array}$ & Global & ONU-1960 & Não vinculante. & Não \\
\hline $\begin{array}{l}\text { Convenção } \text { Internacional } \\
\text { sobre a eliminação de Todas } \\
\text { as Formas de Discriminação } \\
\text { Racial. }\end{array}$ & Global & ONU-1965 & $\begin{array}{l}\begin{array}{l}\text { Sim, em } 1966 . \\
\text { Com }\end{array} \\
\text { vinculante. }\end{array}$ & Não \\
\hline $\begin{array}{l}\text { Pacto Internacional sobre os } \\
\text { direitos Civis e políticos. }\end{array}$ & Global & ONU-1966 & $\begin{array}{l}\text { Sim, em } 1992 . \\
\text { Força vinculante. }\end{array}$ & Não \\
\hline $\begin{array}{l}\text { Pacto Internacional sobre os } \\
\text { direitos Econômicos, Sociais e } \\
\text { Culturais. }\end{array}$ & Global & ONU-1966 & $\begin{array}{l}\text { Sim, em } 1992 . \\
\text { Força vinculante. }\end{array}$ & Não \\
\hline $\begin{array}{l}\text { Declaração sobre a Raça e os } \\
\text { Preconceitos Raciais. }\end{array}$ & Global & ONU-1978 & $\begin{array}{l}\text { Sem força } \\
\text { vinculante. }\end{array}$ & Não \\
\hline $\begin{array}{l}\text { Convenção } 169 \text { sobre Povos } \\
\text { Indígenas e Tribais. }\end{array}$ & Global & OIT-1989 & $\begin{array}{l}\text { Sim, em } 2002 . \\
\text { Força vinculante. }\end{array}$ & Não \\
\hline 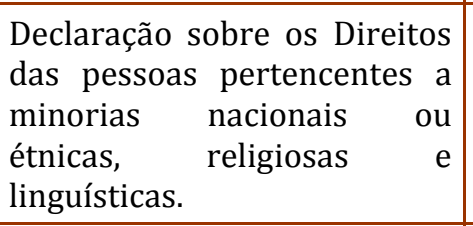 & Global & ONU-1992 & $\begin{array}{l}\text { Sem força } \\
\text { vinculante. }\end{array}$ & Não \\
\hline $\begin{array}{l}\text { Declaração e Programa de } \\
\text { Ação de Durban }\end{array}$ & Global & ONU-2001 & $\begin{array}{l}\text { Sim. Sem força } \\
\text { vinculante. }\end{array}$ & Sim \\
\hline $\begin{array}{l}\text { Convenção Americana de } \\
\text { Direitos Humanos. }\end{array}$ & Regional & OEA-1969 & $\begin{array}{l}\text { Sim, em } 1992 . \\
\text { Força vinculante. }\end{array}$ & Não \\
\hline $\begin{array}{l}\text { Convenção Interamericana } \\
\text { contra toda forma de } \\
\text { Discriminação e Intolerância. }\end{array}$ & Regional & OEA-2013 & $\begin{array}{l}\text { Sim, em } 2013 . \\
\text { Força vinculante. }\end{array}$ & Não \\
\hline 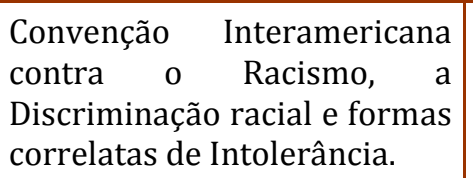 & Regional & OEA-2013 & $\begin{array}{l}\text { Sim, em } 2013 . \\
\text { Força vinculante. }\end{array}$ & Não \\
\hline
\end{tabular}

Fonte: Elaboração da autora.

De acordo com o Quadro 1, verifiquei a menção da memória em apenas um documento de diretos humanos: a Declaração e Programa de Ação de Durban (2001), na qual a palavra memória é citada três vezes: 
Unindo-nos em um espírito de renovada vontade política e compromisso com a igualdade universal, com a justiça e a dignidade, rendemos homenagens à memória de todas as vítimas do racismo, discriminação racial, xenofobia e intolerância correlata, em todo o mundo e, solenemente, adotamos a Declaração e o Programa da Ação de Durban [...].

Reconhecemos e profundamente lamentamos os enormes sofrimentos humanos e o trágico padecimento de milhões de homens, mulheres e crianças causado pela escravidão, pelo tráfico de escravos, pelo tráfico transatlântico de escravos, pelo apartheid, pelo colonialismo e pelo genocídio, e convocamos os Estados a se preocuparem em honrar a memória das vítimas de tragédias do passado, e afirmamos que onde e quando quer que tenham ocorrido, devem ser condenados e sua recorrência evitada [...].

Visando por um fim a estes capítulos obscuros da história e como um meio de reconciliação e cura das feridas, convidamos a comunidade internacional e seus membros a honrarem a memória das vítimas destas tragédias [...]. (grifos nossos).

Por ser um texto de natureza declaratória, a memória é mencionada dentro das proposições históricas enquanto ato simbólico e não como direito a ser garantido pelo Estado. Apesar da forma tímida, o trecho "convocamos os Estados a se preocuparem em honrar a memória das vítimas de tragédias do passado" abre janelas para a discussão sobre o enquadramento da memória na lista de ações que deverão ser adotadas pelo Estado enquanto medidas de enfrentamento da discriminação e da desigualdade em função da raça, etnia e cor.

Tendo em vista que as duas últimas menções à memória se encontram na seção de "estabelecimento de recursos e medidas eficazes de reparação, ressarcimento, indenização e outras medidas em níveis nacional, regional e Internacional”, não restam dúvidas de que a revisão e a valorização da memória é um dever moral do Estado.

A Conferência de Durban contra o Racismo e a Discriminação Racial, realizada na África do Sul "pós-apartheid", foi "uma proposta lançada pela Subcomissão para a prevenção da Discriminação e Proteção das Minorias da ONU" com o intuito de encontrar um novo caminho para o enfrentamento do racismo "persistente há duas décadas já que o programa de ação da primeira década de combate ao racismo iniciou-se em 1973 de acordo com a resolução 3057 (XXVIII)". A segunda foi estabelecida pela Resolução 35/33 no ano de 1983, "com objetivo de avaliar as atividades da primeira década" (ALVES, 2002, p. 200).

A natureza da conferência de Durban apresentou para o Sul um enfoque diferente: a raça enquanto um processo de significação. Neste sentido, os modos de reparações, como o da escravidão, "que se associava a ideia de um pedido de perdão 
pelo colonialismo", envolviam propostas que variavam desde "a adoção de políticas públicas eficazes", como "cotas", "indenizações em dinheiro aos descendentes vivos dos escravos" e diversas formas de assistência, como, por exemplo, a estudantil. Estas formas de reparações, bem como os pedidos de perdão relacionados à escravidão e ao colonialismo, são maneiras de restabelecer a dignidade das vítimas (ALVES, 2002, p. 205-213).

Entre os objetivos expostos na referida Declaração vale mencionar a urgência de se examinar tanto o progresso quanto os obstáculos encontrados para mitigar os problemas. Além disso, seria necessária uma ampla conscientização, no sentido de formular possíveis recomendações, como a de "rever os fatores políticos, históricos, econômicos, sociais, culturais e de outra ordem conducentes ao racismo, à discriminação racial, à xenofobia e à intolerância correlata" (ALVES, 2002, p. 203).

De acordo com Alves (2002), a inserção do resgate histórico na Declaração de Durban foi um dos pontos mais positivos da Declaração, uma vez que estabelece referências de racismo não apenas contemporâneas, mas estruturalmente históricas, como o colonialismo.

À luz destas medidas, nota-se que a memória foi adotada como um objeto de discurso honroso. Ou seja, acreditou-se que a homenagem, ao promover o resgate histórico, tornaria presente o que estava ausente, ao mesmo tempo em que coibiria possíveis repetições. Esta lógica aristotélica de rememorar, bem como a de prevenir para que não haja repetição, como defende Primo Levi (1988), são seguimentos tanto da memória da ditadura militar quanto do genocídio. Entretanto, honrar a memória seria o mesmo que garanti-la?

De acordo com essas considerações, exponho a seguir dois quadros, nos quais é possível verificar a motivação para essa dúvida relativa a uma possível garantia do direito à memória. 0 primeiro se refere à construção sobre a memória da ditadura militar ocorrida no Brasil em virtude de um anseio da social em reivindicar a verdade, que acabou se tornando uma contra memória por refutar narrativas oficiais.

O segundo quadro refere-se ao "direito à memória do genocídio". São memórias também reivindicadas pelas vítimas perante o Estado que, igualmente, confrontam as narrativas oficiais. Contudo, do mesmo modo que a memória da ditadura militar apresenta vulnerabilidades em sua garantia, devido aos problemas como o acesso à 
memória, sequestro de narrativas e seleção de quem poderia ser ou não ser sujeito histórico.

No quadro a seguir exponho o conteúdo inscrito no dispositivo constitucional da República Federativa do Brasil (artigo 216 da Constituição Federal), as menções sobre a memória abarcada no Plano Nacional de Direitos Humanos número 3 (PNDH3), o caso Guerrilha do Araguaia julgado perante a Corte Interamericana de Direitos Humanos e outros marcos históricos resultantes de lutas tanto das vítimas como de movimentos sociais - os dois atores principais para a construção da memória da ditadura militar.

Quadro 2 -Panorama jurídico e histórico da Ditadura Militar no Brasil

\begin{tabular}{|c|c|}
\hline \multicolumn{2}{|c|}{ PANORAMA JURÍDICO E HISTÓRICO DA DITADURA MILITAR NO BRASIL } \\
\hline Documentos Legais/ Jurisprudenciais & Marcos Históricos \\
\hline $\begin{array}{l}\text { Artigo } 8^{0} \text { do Ato das Disposições Constitucionais Transitórias a } \\
\text { concessão de "anistia" regulamentada pela Lei n. } 10.559 / 02 \text {, que } \\
\text { criou o regime jurídico do anistiado político e instituiu a Comissão } \\
\text { de Anistia. }\end{array}$ & $\begin{array}{l}1995 \text { - Comissão Especial sobre } \\
\text { Mortos e Desaparecidos Políticos- Lei } \\
\text { n. } 9.140\end{array}$ \\
\hline $\begin{array}{l}\text { Art. 216. Constituem patrimônio cultural brasileiro os bens de } \\
\text { natureza material e imaterial, tomados individualmente ou em } \\
\text { conjunto, portadores de referência à identidade, à ação, à memória } \\
\text { dos diferentes grupos formadores da sociedade brasileira. }\end{array}$ & $\begin{array}{l}2001 \text { - Comissão de Anistia- Medida } \\
\text { Provisória n. } 2.151\end{array}$ \\
\hline $\begin{array}{l}\text { Plano Nacional de Direitos Humanos - PNDH3 instituído pelo } \\
\text { Decreto n. } 7.037 \text {, de } 21 \text { de dezembro de } 2009 \text {, e atualizado pelo } \\
\text { Decreto n. } 7.177 \text { de } 12 \text { de maio de } 2010 \text {. }\end{array}$ & $\begin{array}{l}2011 \text { - Comissão Nacional da } \\
\text { Verdade- Lei n. } 12.528\end{array}$ \\
\hline \multirow{2}{*}{$\begin{array}{l}\text { Caso Gomes Lund (Guerrilha do Araguaia) julgado em dezembro } \\
\text { de } 2010 \text { Brasil. O caso foi levado à Corte Interamericana de } \\
\text { Direitos Humanos em } 2009 \text {. }\end{array}$} & 2012 - Comissões Estudantis \\
\hline & 1. Anísio Teixeira \\
\hline \multirow{2}{*}{$\begin{array}{l}\text { Primeiro relatório da Comissão Nacional da Verdade - dezembro } \\
2014\end{array}$} & Criação de memoriais \\
\hline & 1.Memórias Reveladas - 2009 \\
\hline - & Caravanas da Anistia \\
\hline
\end{tabular}

Fonte: Elaboração da autora.

A lei no 10.559 de 2002 não faz menção à memória em seu rol. Por sua vez, o artigo 216 da Constituição Federal defende a memória dos diferentes grupos formadores da sociedade brasileira como um patrimônio cultural brasileiro. Já oPNDH3 reconhece expressamente como direito a memória histórica como pilar fundamental para "afirmar a importância da memória e da verdade como princípios históricos dos Direitos Humanos", responsáveis tanto pela "construção da identidade social e cultural 
de um povo e na formulação de pactos que assegurem a não repetição de violações de Direitos Humanos, rotineiras em todas as ditaduras" (BRASIL, 2010, p. 19).

0 resgate da memória por meio da reconstrução histórica dos movimentos sociais é apontado como um objetivo estratégico do quinto eixo orientador de "Educação e Cultura em Direitos Humanos". 0 eixo orientador número 6 delimitado de "Direito à memória e à verdade" destaca na diretriz 23 a importância do "reconhecimento da memória e da verdade como Direito Humano da cidadania e dever do Estado". Do mesmo modo, as diretrizes de número 24 e 25 determinam respectivamente "a preservação da memória histórica e a construção pública da verdade" e "a modernização da legislação relacionada com a promoção do direito à memória e à verdade fortalecendo a democracia" (BRASIL, 2010, p. 176).

Por sua vez, o caso guerrilha do Araguaia, também conhecido como Gomes Lund, trata da detenção arbitrária, da tortura e do desaparecimento forçado de 70 pessoas entre elas as do Partido Comunista do Brasil - em virtude das operações do Exército brasileiro. O Exército foi orientado pelo regime ditatorial a se utilizar de quaisquer medidas para erradicar a referida guerrilha. A condenação do Brasil pela Corte Interamericana de Direitos Humanos, proferida após 35 anos do ocorrido, expõe em seu texto que o referido caso foi importante para a garantia do direito à memória e à verdade, para preservar a memória coletiva, bem como para reparar graves violações de direitos humanos (CORTE INTERAMERICANA DE DIREITOS HUMANOS, 2010).

Durante a busca pela menção da memória nesses referenciais não encontrei a existência de uma lei que reconhecesse especificamente "o direito à memória do período autoritário da Ditadura Militar". Isso não quer dizer que ela não exista. Apesar de não estar positivada, sua existência é comprovada pelos marcos históricos.

Além disso, cabe pontuar que a memória da ditadura militar é a única memória de fato inserida no campo relativo às memórias históricas nacionais de busca pela verdade. Vale dizer que o lócus da memória histórica e a busca pela verdade se restringem à memória da ditadura militar. Outros eventos históricos, também órfãos de verdade, ainda não se somaram a esse campo.

Categoricamente falando, seria interessante mobilizar a construção de um campo em aberto da memória no qual fosse possível inserir, quando reivindicado, histórias censuradas de diversos povos, independentemente do tempo e do espaço geográfico em que ocorreram. Como exemplo, cito a busca pela verdade sobre a história colonial nas 
Américas e sobre as nossas linhagens não brancas. Tais histórias teriam um abrigo não hierarquizado, mas de completude. Sob esse prisma, esse campo global se traduziria num "direito à memória das verdades históricas".

Seguindo a mesma lógica do percurso que utilizei para afirmar a memória da ditadura militar como um direito, expus um aporte mínimo legal e histórico para justificar a memória do genocídio como o segundo tipo de categoria oficial de direito à memória.

Quadro 3 -Panorama jurídico e histórico do Genocídio

\begin{tabular}{|c|c|}
\hline \multicolumn{2}{|c|}{ PANORAMA JURÍDICO E HISTÓRICO DO GENOCÍDIO } \\
\hline Documentos Legais & Marcos Históricos \\
\hline Âmbito externo & ONU \\
\hline $\begin{array}{l}\text { ONU } \\
\text { Convenção para a Prevenção e a Repressão do Crime de } \\
\text { Genocídio (1948). }\end{array}$ & $\begin{array}{l}\text { Dia Internacional em } \text { Memória do } \\
\text { Holocausto ( } 27 \text { de janeiro). }\end{array}$ \\
\hline Âmbito externo & ONU \\
\hline $\begin{array}{l}\text { ONU } \\
\text { Estatuto de Roma aprovado em } 17 \text { de Julho de } 1998 .\end{array}$ & $\begin{array}{l}\text { Dia Internacional de Reflexão sobre o } \\
\text { Genocídio em Ruanda ( } 07 \text { de abril). }\end{array}$ \\
\hline Estatuto de Roma aprovado em 17 de Julho de 1998. & $\begin{array}{l}\text { Programa de Divulgação sobre o Genocídio } \\
\text { em Ruanda e as Nações Unidas. Criado a } \\
\text { partir decisão da Assembleia Geral de } 23 \text { de } \\
\text { dezembro de } 2005 \text {. }\end{array}$ \\
\hline Âmbito interno & \multirow[b]{2}{*}{$\begin{array}{l}\text { Obs.: o genocídio indígena nas Américas, o } \\
\text { cigano, o tibetano, dos assírios, dos servos, o } \\
\text { ucraniano (holomodor), o armênio, da } \\
\text { Cambódia, entre outros, não são } \\
\text { reconhecidos oficialmente pela ONU como } \\
\text { crimes de genocídio. }\end{array}$} \\
\hline Lei n. 2.889/1956 - Define e pune o genocídio. & \\
\hline Âmbito interno & \multirow[b]{2}{*}{-} \\
\hline $\begin{array}{l}\text { Decreto n. } 4388 / 2002 \text { - Promulga o Estatuto de Roma do } \\
\text { Tribunal Penal Internacional }\end{array}$ & \\
\hline
\end{tabular}

Fonte:Elaboração da autora.

Em nenhum dos documentos legais listados, tanto do âmbito interno quanto externo, a palavra memória foi citada. Neste sentido, é importante notar que muito mais do que um direito, a memória é um espaço de luta para se reivindicar outros direitos, 
entre eles, o direito à verdade que se desdobra contra o autoritarismo, seja ele político, jurídico ou histórico.

Os dados analisados nos dois últimos quadros indicam que a construção da memória enquanto direito oscila entre o intercâmbio de leis que apresentam lacunas, jurisprudências responsáveis por este direito de forma genérica e marcos históricos (símbolos de lutas pela garantia do direito à memória).

Além da falta de uma menção específica para cada categoria da memória, cabe destacar o problema das ausências de tipos e subtipos da memória, bem como a marginalização de alguns sujeitos históricos.

Vale enfatizar que, no sentido macro, a categoria de direito à memória apresenta ausências por considerar oficialmente o "direito à memória" de dois tipos: da ditadura e do genocídio. Logo, existe uma conclamada falta de outras memórias no que se refere à tipificação.

Além disso, a memória do genocídio apresenta censuras no subtipo, já que nem todos os eventos genocidas foram enquadrados nesta categoria. Em relação ao subtipo da memória da ditadura pode-se dizer que, de uma forma geral, esta categoria também apresenta um problema de censura, já que nem todos os países que foram ex-colônias e que sofreram intervenções militares em algum momento da sua história possuem a outra versão que não a oficial sobre este período autoritário.

De forma mais nítida, argumento que dentro da categoria da memória do genocídio, nem todos os genocídios se tornaram um direito à memória como, por exemplo, o genocídio colonial. Em relação à marginalização das vítimas, esta é fortemente marcada no contar da memória, tanto da ditadura militar quanto do genocídio.

Deste modo, cumpre enfatizar que dentro do campo destas duas categorias de memórias existem eventos e sujeitos que foram e permanecem censurados pela história e pelo direito, e que tal censura está intimamente relacionada à estrutura racista/moderna do Estado. 


\subsection{O campo das ausências: os sujeitos e os tipos de memórias marginalizados}

Existem duas versões sobre a memória. A primeira é imposta pelo Estado (oficial), que por meio do poder determina universalmente qual evento, quais sujeitos deste evento e como tal evento deve ser recordado. Trata-se de uma memória que almeja a construção de um imaginário nacional homogêneo e programado, o qual se utiliza da assimilação como instrumento de repúdio à dialética da diferença.

Sob este enfoque, ao servir a estratégia de representação e coesão de comunidade política, a memória se consubstancia numa atividade político-jurídica responsável pela gestão, tramitação e reinterpretação do passado, do presente e do futuro da sociedade de uma forma institucional. Logo, este tipo de memória acompanha a emergência dos Estados e tende a se tornar fidedigna aos relatos nacionais (MARÍN; CAIRO, 2013).

A segunda versão da memória é aquela construída pelas vítimas (não oficial). Oscila entre o pessoal e o coletivo e entre o privado e o público. São memórias construídas em virtude do silenciamento, da dor e da insatisfação. Como expõe Hartog (2012) o reconhecimento do trauma enquanto uma categoria psicológica trouxe reconhecimento e visibilidade à condição de vítima, bem como a possibilidade de nomear o sofrimento, ainda que de forma tardia. Apesar de autônomas, quando se tornam públicas ficam vulneráveis às restrições Estatais.

As memórias reivindicadas pelas vítimas articulam demandas por justiça, reparação, verdade histórica e judicial, derivadas de iniciativas de diversos e plurais setores, organizacionais e coletivos (MARÍN; CAIRO, 2013). São lutas que possuem como vetores a solidariedade e a disputa política. Ao longo da história foram automaticamente jogadas no âmbito do que Pollak (1989) denomina de "memórias subterrâneas" por não tecerem narrativas oficiais.

Na esteira destas questões, este tópico irá tratar das memórias não oficiais que sofreram ao longo da história dupla marginalização: a da falta do reconhecimento do evento e da censura de sujeitos. 0 objetivo é acusar o monopólio da memória, bem como apontar os motivos pelos quais alguns tipos de memórias e de sujeitos permanecem sem reconhecimento. 
Para tanto, naveguei entre as negações de dois tipos de memória oficialmente existentes: da ditadura militar e a do genocídio, que permanecerão tomadas como principais subsídios ao longo deste trabalho.

Devido ao enfoque na polarização militar e civil, o campo da memória das ditaduras militares na América Latina - Uruguai 1973-1985; Argentina 1976-1983; Chile 1973-1990; Bolívia 1964-1982; e Paraguai 1954-1989 - reservaram, aparentemente, um lugar preterido para o recorte de gênero, de raça, de etnia, de classe e de sexualidade.

0 relatório da Comissão Nacional da Verdade brasileira publicado em dezembro de 2014 expõe, no segundo volume, dois eixos temáticos referentes às violações de direitos humanos no período da ditadura contra os trabalhadores, camponeses, indígenas, homossexuais e contra as instituições universitárias e igrejas cristãs. Entretanto, muitos casos ainda estão por ser investigados, registrados e publicizados, ou seja, a violência contra estas pessoas ainda não foi computada, tampouco integrada à lista de mortos e desaparecidos da Comissão Especial sobre Mortos e Desaparecidos Políticos (CEMDP) ${ }^{31}$. Isto nos leva à seguinte pergunta: quem são os mortos e os desaparecidos na compreensão da CEMDP?

Além disso, o referido relatório não faz menção à raça nem ao gênero em nenhuma das 416 páginas, sendo estes dois elementos rudimentares para a compreensão de violações de direitos humanos cometidas neste período.

Entre estes casos que ainda serão apurados pela Comissão da Verdade está o Relatório Figueiredo, referente ao período de 1946 a 1988. Este documento, dado como queimado em um incêndio ocorrido no Ministério da Cultura, foi encontrado no ano de 2013 no Museu do índio, no Rio de Janeiro. Apesar da deterioração, o referido relatório acusa nas suas sete mil páginas as "caçadas humanas", que através da tortura e da matança buscavam exterminar as comunidades indígenas. Entre as formas de extermínio estão o uso de "metralhadoras e dinamites de aviões, inoculações propositais de varíola em povoados isolados e doações de açúcar misturado a estricnina". Além

31 O livro-relatório compilado ao longo de 11 anos, no qual há o registro do trabalho realizado pela CEMDP, reconhece 475 casos em que houve desaparecimentos e mortes provocadas pelos agentes do Estado. Nenhum destes casos se refere às mortes das minorias. Além disso, não lhes foi reservada, no referido livro, uma seção como a dos "argentinos desaparecidos no Brasil". No entanto, destaca-se que no caso dos argentinos, também não computados, houve publicização, ou seja, não foram silenciados pela CEMDP, como foram as minorias. 
disso, consta que os índios foram postos em regimes de escravidão, sendo-lhes negados o mínimo de condição de vida compatível com a dignidade da pessoa humana ${ }^{32}$.

Ainda sobre esta questão, vale apontar que o Grupo de Trabalho Indígena, que não era uma proposta inicial da CNV, surge após a pressão de organizações de direitos humanos (FAERMAN; WEIS, 2015). Contudo, a única produção deste grupo relativa aos camponeses e povos indígenas, entre outros já citados, se reduz a textos autorais dos membros da CNV que não alcançam nem comportam a complexidade, tampouco as múltiplas dimensões de violações contra esses povos.

Tanto os testemunhos quantos as evidências documentais colhidas pela CNV não se dão conta sobre a necessidade de apontar, nomear e associar a raça às violações de direitos humanos. É importante enfatizar que as violações referentes aos indígenas não se restringem à questão da terra. Na verdade, elas estão atreladas às questões raciais.

Sob este invólucro, a raça passa a ocupar um espaço de fragmentação em vez de significação da experiência real que comporta as violações de direitos humanos. Portanto, para que exista um aprofundamento sobre tais violações contra a população indígena é imprescindível que raça se torne objeto metodológico da CNV.

A verdade deve ser buscada em todos os aspectos. De que maneira se poderia discutir sobre responsabilização e reparação de tais violações sem que haja a caracterização da raça? A violência permanece incrustada na vida destas comunidades até hoje porque o racismo é um modelo de sociedade. Este modelo deveria ser questionado nos relatórios.

Como se sabe, a ditadura militar é um dos capítulos do "processo colonizador, primeiramente metropolitano e depois republicano" 33. Vejamos alguns exemplos desta reprodução autoritária e hierárquica. O Serviço de Proteção ao Índio (SPI), extinto pelo governo militar e substituído pela Fundação Nacional do Índio (FUNAI), possuía uma política de extrema violência contra os indígenas. Com a criação da Guarda Rural durante o período ascensão do poder militar houve o reforço dessa violência. A guarda rural era uma escola de tortura, na qual os indígenas eram pagos para agir contra a sua própria cultura tanto fora quanto dentro de suas comunidades.

\footnotetext{
32 O relatório Figueiredo encontra-se disponível no endereço eletrônico do Ministério Público Federal: http://6ccr.pgr.mpf.mp.br/institucional/grupos-de-trabalho/gt_crimes_ditadura/relatorio-figueiredo. Acesso em: 15 jan. 2015.

33 Concepção da antropóloga Rita Laura Segato (2010).
} 
Por sua vez, o mito da democracia racial implantado na fundação da República alegava que o Brasil possuía um projeto político pautado na igualdade, portanto, não existia racismo. Com a falta de conhecimento das diferenças, o racismo é, então, desvinculado dos problemas de desigualdade econômica e social, ao mesmo tempo em que serve à ideia de desenvolvimento pautada no posicionamento ideológico de branqueamento. Nestes termos, vale observar que a raça não é apenas um atributo colonial dado aos grupos raciais que foi se reproduzindo, mas uma consequência de uma prática estatal racista.

Sob estas capturas, considero que os estudos sobre os casos de violações de direitos humanos contra os indígenas e também contra os negros ainda estão aprisionados no período autoritário da ditadura militar como se fossem atos singulares a este período. Contudo, tais violações são a continuidade de uma violência que “começou com os genocídios perpetrados pelos agentes das metrópoles coloniais e dos Estados nacionais" (SEGATO, 2010, p. 144).

Muitas dessas violações permanecem em curso, mesmo que não estejamos vivenciando uma ditadura propriamente dita, porque a colonialidade se encontra concentrada em todos os setores das elites. Ressalta-se que tais setores continuaram alimentando o processo de violações responsável por dar sequência ao que Bartolomé Clavero denomina de genocídios cotidianos ${ }^{34}$.

O genocídio negro introduziu o Brasil no ranking dos países com maiores índices de execuções extraoficiais e de altíssimo grau de letalidade policial. Como explica Segato (2010), grande parte destas mortes foi operada pela segurança pública, mas o silenciamento sobre a raça verificado nos laudos e registros policiais dificulta a precisão desta categoria de não brancura.

A respeito do genocídio indígena no Brasil, cabe destacar que o Estado, ao mesmo tempo em que censura os direitos dos povos indígenas, aprova normas lesivas a eles e opera por meio de agentes estatais como não estatais para exterminá-los. Logo, o Estado, além de negar os direitos já conquistados por estes povos, ainda impede o avanço de novos direitos.

${ }^{34}$ As obras de Bartolomé Clavero encontram-se disponíveis em: http://www.bartolomeclavero.net/?cat=10. Acesso em: 15 jan. 2015. 
O relatório compilado pelo Conselho Indigenista Missionário (CIMI, 2015) com dados de 2014 sobre a perpetração da violência contra os povos indígenas no Brasil apontou que entre as principais violações estão:

- Contra o patrimônio. Envolve questões sobre a omissão e morosidade na regularização de terras, conflitos territoriais, invasões possessórias e exploração ilegal de recursos naturais.

- Contra a pessoa. São crimes de assassinatos, abuso de poder, racismo e discriminação étnico-culturais, violência sexual, entre outros.

- Provocadas por omissão do poder público. Registram suicídio, mortes por desassistência à saúde, disseminação de bebida alcoólica e outras drogas, desassistência educacional, entre outras (CIMI, 2015).

Sobre a continuidade desta mentalidade colonialista, militarista, o relatório expõe: "apesar da superação da ditadura militar, as violência contra esses povos foram atualizadas e intensificadas. Ainda ocorrem no Brasil, em pleno século XXI, situações de genocídio e etnocídio" (CIMI, 2015, p. 7).

Ademais, a FUNAI, órgão indigenista oficial do país, se demonstra impotente em relação aos casos de identificação, delimitação e demarcação de terras. A falta de um Ministério específico para questões indígenas estimula a omissão estatal frente às suas obrigações. Outro mecanismo de poder que compõe esta quadrilha é a mídia, que, através do silenciamento sobre os homicídios perpetrados por fazendeiros, policiais e outras forças locais, principalmente as de interesse no agronegócio, bem como da produção de matérias tendenciosas que criminalizam os índios, contribui de forma assombrosa com o genocídio indígena.

Logo, não se trata somente de se pensar na garantia e promoção dos direitos dos povos indígenas enquanto cidadãos, há também que se pensar no outro lado: na reparação das violências já apuradas, bem como na punição destes criminosos que não são julgados por suas execuções, tampouco por suas omissões.

Ainda sobre a censura, mas agora das vítimas, cabe apontar que existe "uma distribuição hierárquica de sujeitos na história” 35 , que possui como marco temporal a modernidade. De acordo com esta versão, os sujeitos considerados modernos estão

35 Termo utilizado pelo autor Mario Rufer quando dissertou sobre Nação, diferença e temporalidade a partir das perspectivas pós-coloniais do Sul-Sul. 
aptos para compor a história da humanidade, os considerados fora do tempo da modernidade, não.

Nenhum evento latino-americano, como a escravidão negra e indígena, considerados anteriores ao marco da modernidade, obteve reconhecimento e reparação internacional. Diante disso, algumas memórias não integraram os marcos nacionais. Além de não se tornarem memórias da humanidade por terem sido negadas, também foi negado às vítimas o caráter de vítimas.

Um exemplo desta hierarquia, curiosamente esquematizada no âmbito do próprio evento do holocausto é o "Dia Internacional de Comemoração em Memória das Vítimas do Holocausto", o qual homenageia, sobretudo, os judeus. As outras vítimas são constantemente esquecidas no meio acadêmico, social e político.

Usadas como objetos de extermínio, estas vítimas foram identificadas por uma triangulação de cores distintas. Os ciganos, representados pelo triângulo marrom, por serem considerados pela ideologia nazista como racialmente inferiores, preguiçosos e antissociais, foram exterminados em câmeras de gás assim como os judeus nos campos de extermínio para famílias ciganas ${ }^{36}$.

Os outros prisioneiros eram enviados para o campo de concentração como forma de punição. Mesmo não sendo mandados para os campos de extermínio, eles morriam por doenças, inanição, fome, exaustão e como resultado da violência moral e física que sofriam. Os prisioneiros políticos como os comunistas, socialistas e sindicalistas eram representados pelo triângulo vermelho e, assim como as Testemunhas de Jeová (triangulo roxo), foram perseguidos por serem uma suposta ameaça à ideologia racial nazista ${ }^{37}$.

Os homossexuais, associados ao triângulo de cor rosa, eram vistos como um sinal de decadência alemã. Os homossexuais masculinos eram rotulados de fracos, afeminados e incapazes de lutarem em prol da própria nação, além de uma ameaça à taxa de natalidade devido à impotência reprodutiva. Com o intuito de encontrar uma cura para a homossexualidade, eles eram enviados aos campos, onde sofriam castrações,

\footnotetext{
36 Informações encontradas no site do United States Holocaust Memorial Museum (Museu do Memorial do Holocausto dos Estados Unidos). Disponível em: <http://www.ushmm.org>. Acesso em: 07 jul. 2015.

37 United States Holocaust Memorial Museum. Disponível em: http://www.ushmm.org/. Acesso em: 07 jul. 2015.
} 
mutilações, abusos e eram obrigados a realizarem tarefas fatais. Não há considerações sobre as lésbicas durante este período ${ }^{38}$.

A ideologia nazista exterminou milhões de pessoas sem considerar a idade ou o gênero. Alguns campos aprisionavam mulheres judias e não judias, as quais eram sadicamente usadas como cobaias em experiências médicas antiéticas e, por vezes, cruéis, além de serem estupradas, espancadas e forçadas a realizarem tarefas árduas fatais. As crianças, também vulneráveis, eram assassinadas por duas razões: por pertencerem a um grupo racial ou por ameaça ideológica. As pessoas portadoras de deficiência também foram capturadas, isoladas, esterilizadas e exterminadas ${ }^{39}$. Dessa forma, apesar de sempre escutarmos e aprendermos que o holocausto exterminou seis milhões de judeus, eles não foram as únicas vítimas. Que cargas simbólicas estas vítimas carregam a ponto de não serem inseridas pela história no mesmo plano protagonístico ascendido pelos judeus?

A partir de cenários como estes, é possível salientar que a imagem de vítima opera como instrumento de um discurso moralizador da História-Nação. Digo moralizador porque somente é atribuído a algumas vítimas o caráter de vítimas. Logo, o esquecimento destas pela história é considerado menos digno do que as vítimas que são seletivamente escolhidas para compor o projeto histórico da humanidade. Esta seletividade leva em consideração, principalmente, a temporalidade, a posição geográfica e a raça. E por isso, não só as vítimas, mas alguns eventos permanecem no limbo do esquecimento.

No âmbito da categoria do crime de genocídio existem outros eventos, como o extermínio em Camboja, em que os descendentes das vítimas permanecem lutando pelo reconhecimento da configuração desse ato como crime de genocídio. Não muito diferente, o genocídio armênio, apesar de ser reconhecido por 24 países e por 12 Organizações internacionais ${ }^{40}$, também não possuiu o reconhecimento da $\mathrm{ONU}$ enquanto crime de genocídio. Outro exemplo é o evento conhecido como "La matanza de Salsipuedes", um extermínio indígena ocorrido no Uruguai.

38 United StatesHolocaust Memorial Museum. Disponível em: http://www.ushmm.org/. Acesso em: 07 jul. 2015.

39 United StatesHolocaust Memorial Museum. Disponível em: http://www.ushmm.org/. Acesso em: 07 jul. 2015.

40 A lista dos países, organizações e personalidades que reconhecem o genocídio armênio encontra-se disponível em: http://genocidioarmenio.com.br/historia/quem-reconhece/. Acesso em: 07 jul. 2015. 
Apesar de terem ocorrido em épocas diferentes, nota-se que as configurações dos modelos jurídicos não encontraram nestes tipos de genocídios elementos que configurassem uma lógica genocida.

Não por acaso, os genocídios praticados contra os sujeitos exterminados não brancos - como os perpetuados contra tribos, grupos ou comunidades racializadas e que, por esta razão, não eram reconhecidos como nações - foram arremessados para o banco de espera de um ilusório reconhecimento internacional.

Sendo assim, a concepção sobre genocídio tem fundamento nas ideologias não só racistas, mas políticas nacionalistas que legitimam o Estado moderno. Muito mais do que uma falta de reconhecimento, trata-se de uma negação que está estritamente ligada ao fato de o genocídio ser uma estrutura racista construída a partir da modernidade. Como expôs Quijano (2000), o racismo e a modernidade são faces da mesma moeda.

Ao discutir sobre tempo e narração a partir de uma perspectiva pós-colonial, Rufer (2011, p. 16) aponta para a preocupação da "presencia del subalterno na evidencia histórica" , visto que a marca da escritura histórica é do sujeito teórico europeu.

Esta coerção dificulta a nomeação de “outras" memórias, além de atuar como "una práctica racional y com efectos sociales y políticos que exceden a materialidade de la eliminación de masas". Logo, é um modelo que "conduce a la humanidad a su destrucción moral" (FEIERSTEIN, 2011, p. 139).

A barreira histórica que impede o reconhecimento de "outros" genocídios está na “co-existencia”, na "co-presencia”, no risco que a tolerância traria tanto para o caráter contemporâneo quanto para a "imagen temporal homogénea", a qual poderia ser alterada pelo reconhecimento da diferença (RUFER, 2010, p. 17).

Politicamente, muito se discute sobre a singularidade do Holocausto. 0 debate gira em torno dos dilemas sobre a excepcionalidade deste evento devido ao "número de vítimas, aos métodos e eficiência na execução, e a questão do dolo do Holocausto como prova de seu status único no violento contexto da modernidade" (FLAUZINA, 2014, p. 132). Sobre esta questão, o autor Lindgren Alves (2002), ao abordar o conflito árabeisraelense no Oriente Médio, expõe que os árabes defendiam o sionismo - mesmo sendo este abolido pela ONU em 1993 - enquanto uma forma de racismo que causava sofrimento aos palestinos, constituindo "um novo holocausto", uma vez que entendiam a autodeterminação como "equiparação do Estado de Israel à Alemanha de Hitler". A aceitação deste "novo holocausto" ou de outros "holocaustos" "banalizaria o extermínio 
metódico dos judeus nos campos nazistas como um fenômeno não-excepcional" (ALVES, 2002, p. 204).

Esta concepção de "unicidade foi interpelada pela primeira vez pelo historiador David Stannard, sob o fundamento de que o primeiro genocídio ocorreu durante o processo de colonização das populações indígenas nas Américas". Contudo, o fato de o Holocausto ser utilizado como parâmetro de reconhecimento de outros genocídios “silencia os extermínios passados responsáveis pela fundação dos Estados Modernos" (FLAUZINA, 2014, p. 133).

Cabe ressaltar que a primeira definição de genocídio foi desenvolvida pelo advogado judaico Raphael Lemkin a partir de reflexões sobre "os impulsos colonialistas e imperialistas". Ou seja, a sua teoria debruçou-se "sobre a questão da moralidade da colonização europeia como uma preocupação central, desde a invasão e dominação das Américas no século XV". É importante notar que "foram estes princípios que guiaram a execução das modernas formas de genocídio, como o holocausto" (FLAUZINA, 2014, p.122-123).

Em relação à nomeação do genocídio, existe uma discussão de que a convocação de outros crimes cometidos anteriormente à criação desta concepção seriam incabíveis devido à inexistência deste conceito. Entretanto, este argumento não invalida a existência destes crimes precedentes, ainda mais se levarmos em consideração o princípio da retroatividade, o qual não impõe um limite de tempo para processar esses crimes, tornando-os imprescritíveis (DE BAETS, 2010).

Esse princípio abre janelas para que crimes como o genocídio, cometidos anteriormente à criação deste conceito, sejam chamados desta forma. Seria uma forma de desconstruir conceitos forjados que encobrem realidades específicas, bem como de criar melhores condições para o exercício do direito de lembrar o passado (DE BAETS, 2010).

Cumpre observar que o conceito sobre o genocídio, juridicamente naturalizado, se estruturou a partir da experiência do holocausto e, por esta razão, simboliza um etnocentrismo europeu. 0 etnocentrismo é um fenômeno racional que pode ser construído por qualquer cultura, visto que atua por meio de uma colocação central de valores. Tal colocação se inicia na constatação das diferenças e se perpetua a partir do julgamento sobre os valores de outras culturas estereotipadas como inferiores (ROCHA, 1988). 
Reforçado pela estrutura positivista jurídica, o encrustamento do etnocentrismo na concepção genocida impede, ao reforçar uma "singularidad exclusiva", o reconhecimento de outras formas genocidas como as dos indígenas assassinados em toda a América, o genocídio colonial (FEIERSTEIN, 2011, p.154). A dúvida sobre a categorização de um crime como genocídio se mantém devido a essa ordem etnocêntrica racista. Não há dúvidas de que a conquista das sociedades indígenas da América se codifica como raça, assim como a limpeza étnica foi praticada pela Alemanha nazista e como a limpeza de sangue é praticada nas lutas religiosas (QUIJANO, 1992).

Sob estas considerações, destaco a existência deste amplo campo das ausências. É neste ponto de interseção dos tipos das memórias silenciadas, negadas, não legitimadas, tampouco resguardadas, que a minha história começa. A minha luta vem reivindicar uma nova categoria de direito à memória, a qual se refere ao resgate das nossas linhagens não brancas.

Contudo, antes de discorrer sobre a minha ferida aberta, cabe dar continuidade ao debate sobre os motivos pelos quais as categorias das memórias censuradas representam não só uma forma de esquecimento, mas uma negação notável no campo normativo dos Direitos Humanos, visto que existe o conhecimento sobre elas, mas não o reconhecimento delas.

Desta forma, orientei a discussão para o sentido afirmativo de que tais negações ocorrem em virtude da linguagem colonial dos direitos humanos. Esta linguagem colonial deve-se: 1. À relação dicotômica das correntes do jusnaturalismo e do juspositivismo, adotadas neste trabalho como premissas argumentativas edificadoras desta linguagem, as quais bloqueiam a expansão de direitos; 2. À construção hegemônica da memória histórica dos direitos humanos.

Sendo assim, serão trabalhados dois caminhos que justificam a colonialidade dos direitos humanos. 0 primeiro refere-se à construção jurídica a partir das correntes do jusnaturalismo e do juspositivismo, e o segundo está relacionado à construção da memória histórica desses direitos. 


\subsection{O jusnaturalismo e o juspositivismo enquanto princípios teóricos basilares de uma linguagem colonial do direito}

A construção histórica do direito teve como fundamento duas linhas principais: a do jusnaturalismo, alusiva aos direitos naturais dos séculos XVII-XVIII, e a do positivismo jurídico, que emergiu a partir das revoluções burguesas do século XVIII.

Tanto a corrente jusnaturalista quanto a positivista são abordadas por Bobbio (1999) de forma trifásica: o clássico, o medieval e o moderno. A par da corrente jusnaturalista, a primeira fase refere-se à concepção cosmológica de que a natureza possui em si sua própria lei. A segunda compreende o pensamento teológico cristão de que Deus é a fonte suprema e que todo homem seria feito à imagem e à semelhança dele. A última fase, também conhecida como jusnaturalismo racionalista, traz uma visão dualista à linha jusnaturalista (o natural e o positivo), ao expor que o homem, por via da razão, pode construir uma nova ordem jurídica, ou seja, para o absolutismo político o monarca possuía direitos divinos.

A primeira fase da corrente positivista associa-se à distinção entre o que é natural e o que é convencionado pelos homens. Para a fase medieval, o homem é o ser supremo da criação, logo, o direito é posto por alguém e não por algo (natureza). Já a fase moderna fundamenta-se no pensamento de que o direito, posto por autoridades soberanas, possui na lei seu reconhecimento.

Esta última fase representa a construção da ordem jurídica global de acordo com os princípios racionais das ciências naturais. Como explica Bobbio: “O positivismo jurídico nasce do esforço de transformar o estudo do direito numa verdadeira e adequada ciência que tivesse as mesmas características das ciências físico-matemáticas, naturais e sociais" (BOBBIO, 1995, p. 135).

Essa projeção mecanicista tornou-se método indispensável para o direito. Logo, a visão sobre o direito, aprisionada no sistema normativo - utilitário, funcional, hierarquizador e uno devido à estatalidade - se embaça nas características mecanicistas pulverizadoras de realidades, ao mesmo tempo em que se afasta de outras ciências como a antropologia, a sociologia, a psicologia, a pedagogia, entre outras. 
O conhecimento baseado na formulação de leis tem como pressuposto a concepção "de ordem e de estabilidade do mundo" no qual "a ideia construída no passado se repete no futuro" (SOUZA SANTOS, 1987, p. 17). Este pensamento corrobora com a concepção de "mundo-máquina" 41 que, através do determinismo mecanicista, busca encontrar uma lei universal que explique de forma homogênea todos os fenômenos sociais.

Neste sentido, cabe notar que o direito é uma expressão da racionalidade científica etnocêntrica. Além de estabelecer um consenso de paradigmas baseado nas características objetiváveis para as diversas histórias de vida, o direito eleva dentro de seu âmbito o dogma antropocêntrico, o qual considera o homem o centro do universo, um ser que devido à suposta característica da autoexistência desvaloriza as condições de existência de outros seres que não os humanos. Esta ruptura cosmológica que parte de uma subjugação eurocêntrica leva ao questionamento sobre as consequências do caráter antropocêntrico - muitas vezes baseados na exploração da natureza - para o direito ${ }^{42}$.

Todas essas características associadas ao pressuposto de superioridade da sociedade ocidental sinalizaram um esforço histórico em se fixar, tanto no âmbito do direito quanto em outros âmbitos, a ideia de uma unidade racial, absoluta e universal, onde somente o homem branco europeu poderia alcançar a verdade.

Porquanto, cabe ressaltar que tanto para a linha jusnaturalista como para a positivista o direito era um fenômeno absoluto, abstrato, imutável e universal. Ou seja, mesmo sendo diversos, tais paradigmas mantiveram, mediante seus respectivos discursos de verdade, alguns indivíduos à margem da sociedade devido ao gênero e/ou raça, opção religiosa e política.

A saber, o jusnaturalismo, de um modo geral, ao criar uma essência de ser humano, não considerou como humanos os escravos e os índios sob o argumento de que estas pessoas não possuíam alma.

As teorias do filósofo Aristóteles, reconhecidas a partir do século XII, baseavamse na defesa da natureza escrava. Para ele, a natureza deu a um o comando e impôs ao

41 Termo criado pelo autor Wallerstein (2007).

42 Sobre esta questão cabe destacar a "Ley de la madre tierra" aprovada pela Assembléia Legislativa Plurinacional da Bolívia, a qual possuiu como principal objetivo estabelecer fundamentos de desenvolvimento em harmonia e equilíbrio com a Mãe terra para se viver bem. Isto iria garantir o fortalecimento dos saberes locais e dos conhecimentos ancestrais, bem como orientar direitos, obrigações e deveres. Neste sentido cabe destacar que o ser humano deixa de deter o monopólio de sujeitos de direitos que passa também a ser ocupado pela Madre Terra. 
outro a submissão. De acordo com esse contexto, os gregos detinham, de direito, poder sobre os bárbaros (inclui índios, negros e mulheres não brancas), uma vez que eles possuíam uma alma servil. Para Aristóteles, os bárbaros e os escravos se confundiam e somente entre os bárbaros a mulher e o escravo se nivelavam ${ }^{43}$.

Sobre esta questão, Vilfredo Pareto expõe:

\begin{abstract}
La teoría de Aristóteles sobre la esclavitud natural es también la de los pueblos civiles modernos para justificar sus conquistas y su dominio sobre pueblos y llamados por ellos de raza inferior. Y como Aristóteles decía que existen hombres naturalmente esclavos y otros patrones, que es conveniente que aquellos sirvan y éstos manden, lo que es además justo y provechoso pata todos; perecidamente los pueblos modernos, que se gratifican ellos mismos con el epíteto de civilizados, dicen existir pueblos que deben naturalmente dominar, y son ellos, y otros pueblos que no menos naturalmente deben obedecer y son aquellos que quieren explotar; siendo justo, conveniente y a todos provechoso que aquellos manden, éstos sirvan. De esto resulta que un inglés, un alemán, un francés, un belga, un italiano, si lucha y muere por la patria esun héroe; pero un africano si osa defender su patria contra esas naciones, es un vil rebelde y un traidor. Y los europeos cumplen el sacrosanto deber de destruir a los africanos, como por ejemplo en el Congo, para enseñarles a ser civilizados. No falta luego quien beatamente admira esta obra "de paz, de progreso, de civilidad". Es necesario agregar que, con hipocresía verdaderamente admirable, los buenos pueblos civiles pretenden hacer el bien de los pueblos a ellos sujetos, cuando los oprimen y aun los destruyen; y tanto amor les dedican que los quieren "libres" por la fuerza. Así los ingleses liberaron a los indios de la "tiranía" de los raía, los alemanes liberaron a los africanos de la "tiranía" de los reyes negros, los franceses liberaron a los habitantes de Madagascar y, para hacerlos más libres, mataron a muchos reduciendo a los otros a un estado que sólo en el nombre no es de esclavitud; así los italianos liberaron a los árabes de la opresión de los turcos. Todo esto es dicho seriamente y hay hasta quien lo cree. El gato atrapa al ratón y se lo come, pero no dice que hace esto por el bien del ratón, no proclama el dogma de la igualdad de todos los animales y no alza hipócritamente los ojos al cielo para adorar al "Padre común ("Trattato di Sociologia Generale", Vol. II). (PARETO apud MARIATEGUI, 1971[2015], on-line).
\end{abstract}

A esse respeito, em Valladolid, surge um intenso debate que gira em torno da teoria de Aristóteles sobre a escravidão natural, responsável por suscitar o questionamento sobre a humanidade ameríndia. Nessa discussão, duas posições diferenciadas se destacam: a do Bartolomé de Las Casas, que versava sobre a injustiça de tornar os índios escravos sem que houvesse uma guerra justa, e do Ginés de Sepulveda, que defendia a escravidão como uma forma de salvar as almas ameríndias, que, segundo ele, eram povos irracionais. 0 tribunal nunca proferiu uma decisão definitiva e os dois se consideram vitoriosos (DUSSEL, 2007).

43 Para mais informaç̧ões, consultar o livro Política, de Aristóteles (2002). 
Somente no século XV, por meio da bula do Papa Pablo III (1537) denominada "Sublimis Deus", os índios foram declarados como verdadeiros homens livres para usar, possuir e gozar de seus direitos.

Outro episódio que merece destaque é o movimento de terror conhecido como caça às bruxas, dirigido pela igreja católica, responsável por construir o estereótipo de que as mulheres ruralistas eram detentoras do mal, uma vez que organizavam revoltas camponesas em prol de condições melhores de vida. Muitas mulheres, inclusive as que não pertenciam à bruxaria, foram queimadas vivas no período da idade média. Atualmente existe uma preocupação das correntes feministas em reconstruir as imagens das bruxas, bem como de exigir a memória do holocausto dessas vítimas.

Por sua vez, o positivismo devido a sua visão monista - atrelada à compreensão do direito enquanto lei, produto do Estado, ou seja, uma expressão dos interesses elitistas - ao reduzir arbitrariamente todo o direito à norma formalizada, negou a “natureza jurídica do que não se adaptava ao seu modelo" (LYRA FILHO, 1980, p. 31). Esta falta de reconhecimento sobre os outros modos de organizações jurídicas como a dos povos tradicionais era (e ainda é) uma maneira de aniquilar modos de vida e de imperativizar que a verdade é única e tem cor, gênero e está geograficamente localizada no Sul global.

Aparelhagem do direito são técnicas e táticas de dominação que reforçam a exclusão de outros modos de vida. Como explica Foucault, um triângulo composto por elementos de poder, direito e verdade é formado dentro desta aparelhagem, cujo poder necessita da verdade para funcionar. É a ciência que detém o monopólio da verdade. 0 direito, ao se compor desses dois elementos, irá "julgar, condenar, classificar, obrigar a tarefas, destinar a certa maneira de viver ou a certa maneira de morrer", em função deste discurso (FOUCAULT, 2005, p. 29).

A par dessas considerações e a respeito das correntes jusnaturalistas e juspositivistas cabe expor a brilhante síntese de que a primeira corrente, em virtude da autoevidência, é insustentável por ser a-histórica. Do mesmo modo, a segunda corrente, ao fazer referência ao caráter objetivo dos contratos jurídicos, deixa de explicar o movimento das leis (SEGATO, 2006a). Neste sentido, o processo de compreensão de direitos requer um esforço crítico em direção contrária a hegemonia. Um caminho possível seria a análise da linguagem do direito. 
O campo de análise delineado desde o início deste trabalho é dos direitos humanos. Com efeito, estou falando sobre a linguagem 'do direito dos direitos humanos', tratada aqui enquanto um instrumento colonizador, visto que serve a dois processos de dominação: 1- de essencialização do ser humano (jusnaturalismo); 2- de atribuição de direitos e deveres universais, bem como a redução do ser humano à categoria de sujeito de direitos (juspositivismo) - teorias debatidas anteriormente.

Além disso, esse processo colonizador abarca não só o âmbito "dos direitos dos direitos humanos", como também a genealogia destes direitos. Sendo assim, a colonização da linguagem dos direitos humanos se dá em dois sentidos: 1- Devido à restrição da construção de direitos em conformidade com princípios das duas correntes já mencionadas; 2- Devido à singularidade da construção da memória histórica destes direitos. Vale destacar que tanto a primeira quanto a segunda possuem um ponto-chave em comum: a imposição de uma só forma de compreender a realidade, seja por meio das vias jurídicas, seja pelas vias históricas. Neste sentido, darei seguimento a este debate de modo a abordar a linguagem colonizadora dos direitos humanos a partir da sua concepção histórica.

\subsection{As mazelas da concepção histórica oficialmente contada sobre os direitos humanos}

Como demonstrou a história oficial dos direitos humanos, anteriormente à queda do absolutismo os direitos eram privilégios, pois se traduziam na soberania do rei. Deste modo, não existiam cidadãos, mas pessoas submetidas à autoridade do rei, os súditos. Este cenário marcado pelo absolutismo desencadeou lutas que se tornaram embriões da construção histórica dos direitos humanos.

Contudo, vale ressaltar que, apesar da compreensão histórica destes direitos se restringirem ao referido contexto, outras lutas em diferentes épocas e contextos geográficos ocorreram mediante o mesmo propósito: contra o abuso do poder e em prol da reivindicação de direitos. Por isso, deveriam ser reconhecidas como pilares históricos dos direitos humanos. 
A noção sobre o processo histórico que dá origem à gramática dos direitos humanos percorre trivialmente três estradas: A Bill of Rights britânica, promulgada em 1689 mediante o contexto histórico de grande intolerância religiosa, motivada principalmente pela revogação do edito de Nantes, que reconhecia a igualdade da liberdade de consciência e da igualdade civil entre católicos e protestantes, limitou os poderes governamentais e garantiu liberdades individuais ${ }^{44}$.

Essa promulgação, além de representar a institucionalização da separação de poderes do Estado, criou garantias institucionais para a proteção dos direitos fundamentais da pessoa humana. Ademais, este documento veio fortalecer a instituição do júri e reafirmar alguns direitos fundamentais dos cidadãos expressos atualmente nas Constituições modernas, como o direito de petição e a proibição de penas cruéis (COMPARATO, 2011).

Em ordem cronológica, a segunda estrada é a Bill of Rights Norte-Americana, de 1789. Esta procedeu ao ato inaugural da democracia moderna representada pela Declaração de Independência dos Estados Unidos. Constituem "cartas fundamentais de emancipação do indivíduo perante os grupos sociais aos quais ele sempre se submeteu: a família, o testamento e as organizações religiosas" (COMPARATO, 2011, p. 123). Nesse contexto, a autonomia individual assume contornos jurídicos e se torna essencial para os direitos individuais.

No último ponto da rota onde se encontra a justificação histórica dos direitos humanos está a Revolução Francesa ${ }^{45}$, ocorrida também em 1789. Representa a libertação contra a tirania monárquica, ou seja, o encerramento de um regime absolutista. Nasce nesse berço a Declaração dos Direitos do Homem e do Cidadão, o primeiro documento constitucional do novo regime político.

Todas essas revoluções burguesas representaram a travessia dos direitos humanos em direitos fundamentais, uma vez que aqueles passaram a ser positivados nas Constituições, nas leis e nos tratados internacionais.

44 Comparato (2011), em sua obra A afirmação histórica dos Direitos Humanos, contextualiza historicamente a Declaração de Direitos da Inglaterra de 1689 e faz apontamentos minuciosos sobre a importância histórica e as principais disposições deste documento.

45 Vale ressaltar que a formação da nação francesa antes da Segunda Guerra Mundial se tornou uma demonstração eficiente da atuação da raça, já que grande parte dos franceses se opôs e resistiu em aceitar como membros desta nação os não brancos, como os filhos dos imigrantes africanos (QUIJANO, 1992). 
Atrás do caráter positivista se escondia a essencialização do ser humano. Isto quer dizer que os direitos naturais foram incorporados às Constituições e Declarações dos revolucionários, principalmente no que diz respeito aos direitos civis. Logo, tais documentos foram lucidamente construídos a partir da marginalização do outro que não homem, branco e heterossexual, perfil que atendia aos interesses políticos e econômicos da cultura burguesa capitalista.

Alguns exemplos que podem incitar um grau de consciência crítica sobre esse contexto são encontrados na própria história destas declarações. A saber, a Declaração dos Direitos do Homem e do Cidadão, a qual nasce no berço da Revolução Francesa de 1789 é estruturada em conformidade com os princípios de direitos naturais. Por essa razão, a definição de cidadão se restringe ao pagador de impostos branco e do sexo masculino.

Por representar a libertação da tirania monárquica, tal documento é formado sob critérios de "igualdade da natureza humana em todas as culturas e classes". Contudo, influenciado pelas "explicações biológicas da diferença", deixou à margem os negros, os judeus, as mulheres, os portadores de deficiência e os índios, todos vistos como biologicamente inferiores e consequentemente descartáveis. Essa "escala biológica do homem" possuía como alicerce o racismo, o antissemitismo e o sexismo (HUNT, 2009, p. 188-189), e enfatizava que cidadão era apenas o homem branco.

A DUDH (1948), ao reproduzir ideias contidas na Declaração de Independência dos Estados Unidos de 1776 e na Declaração dos Direitos do Homem e do Cidadão de 1789, incorporou em seu texto os direitos naturais. Mesmo defendendo a bandeira da consciência histórica como fator essencial para a reconstrução do valor humano, ao se apoiar em princípios declaratórios de direitos humanos e liberdades fundamentais, como a universalidade ${ }^{46}$, inalienabilidade, imprescritibilidade e indivisibilidade de direitos associados à igualdade de proteção, não considerou as diversidade humanas e culturais.

46 Existe um extenso debate sobre o princípio da universalidade que, em termos gerais, gira em torno da discussão se este princípio seria colonizador por determinar os modos de vida do Ocidente como um parâmetro a ser seguido pelo resto do mundo ou se ele serviria como uma abertura para a expressão de outras culturas. Esta discussão se inicia a partir dos preceitos preparatórios da Declaração de 1948, no qual é denunciada as pretensões universalistas e enfatizada a relatividade cultural. De modo a superar esse debate polarizado se encontra em pauta uma justificação intercultural dos direitos humanos. 
Oportunamente destaca-se que o princípio da dignidade humana retoma com veemência os direitos naturais ${ }^{47}$ quando reforça em seu discurso o princípio de que é direito inerente de todo ser humano. Muitas são as discussões sobre os possíveis valores hegemônicos "de ser humano" inseridos neste princípio.

A construção histórica dos direitos humanos está acompanhada dos debates sobre o que são esses direitos, o que são seres humanos e quem são os humanos que possuem dignidade humana. São construções em aberto que não se enquadram confortavelmente em nenhuma resposta definitiva.

Ainda sobre a aprovação da referida Declaração, Cesár Baldi, ao discutir sobre a descolonização do ensino dos direitos humanos, expõe que a Declaração Universal dos Direitos Humanos (DUDH) foi debatida "quando boa parte da África e da Ásia era colônia de países europeus que a assinaram: a barbárie do genocídio judeu era combatida, mas o massacre das populações colonizadas era invisibilizado" (BALDI, 2014, p. 1). Sob esta ótica, é válido o questionamento se tal documento representa uma narrativa resumida e abstrata da história.

Observa-se que as referências históricas utilizadas na constituição do preâmbulo da DUDH reverberam vãos históricos relativos ao direcionamento das violações de direitos humanos na Segunda Guerra Mundial, especialmente no que diz respeito ao Holocausto (DE BAETS, 2010). As lutas contra os processos coloniais, por vezes, genocidas, não serviram de inspiração para a formulação dos principais documentos de direitos humanos. Vale dizer que tais documentos não possuem uma perspectiva sobre a colonização.

Sobre o aspecto normativo da Declaração de 1948, vale destacar que ela iniciou o ciclo de "declaração de direitos". Anteriormente a ela, os direitos se traduziam em petições (Bill), o que obstruía a efetivação da soberania. Então, apresentar os direitos em forma de declaração significava supremacia estatal (HUNT, 2009).

Além da Declaração de 1948, duas conferências mundiais contribuíram perspicazmente para a consolidação dos direitos humanos no campo normativo. A Conferência Mundial de Direitos Humanos, realizada em Teerã, no ano de 1968,

\footnotetext{
47 Alguns autores defendem que os direitos naturais pertencem à época da antiguidade. Contudo, cabe destacar que os direitos naturais que começaram a se desenvolver na antiguidade sofreram transformações devido à sua vulnerabilidade perante os interesses histórico-políticos Estatais. Assim, tais direitos se associaram mais aos direitos do que aos deveres, bem como aos indivíduos muito mais do que aos grupos (HASTRUP, 2001).
} 
destacou "a gradual passagem da fase legislativa, de elaboração dos primeiros instrumentos internacionais de direitos humanos". A segunda Conferência Mundial de Direitos Humanos, realizada em Viena, em 1993, contou com a presença de 171 membros. Por meio deste documento foi promovida "uma reavaliação global da aplicação de tais instrumentos e das perspectivas para o novo século" (CANÇADO TRINDADE, 2004, p. 167-168). É neste seguimento institucionalizado que os direitos humanos adquirem o seu reconhecimento oficial.

A par dessa visão é que a vigência dos direitos humanos revela-se dependente da organização normativa, seja ela doméstica ou internacional. 0 processo histórico de formação dos direitos humanos vem acompanhado pelo "processo de generalização da proteção internacional dos direitos humanos", que atualmente corre o risco de tornar-se insuficiente e anacrônico devido à emersão de outras formas de violações de direitos humanos, ainda marginalizadas pelos órgãos nacionais e internacionais de proteção de direitos (CANÇADO TRINDADE, 2004, p. 172).

Mesmo com a crescente preocupação dos organismos internacionais em construir instrumentos que garantam os direitos já definidos, novas reivindicações de direitos, que simbolizavam mudanças históricas, não passaram pelo filtro do que poderia ser considerado direito, ainda mais quando não atendiam aos preceitos das normas individualistas de direitos humanos.

Como ensina Segato (2006a, p. 212), esse filtro vem expressar o embate entre a lei e a moral. A lei, "administrada por uma visão contratualista da Nação" e constituída tanto por "normas e modos de pensar e julgar quanto por práticas no sentido de ações e formas de interação habituais", entra em colisão com outras crenças que diferem da moral estatal representante dos interesses de classes dominantes, por mais que seja possível articulá-las com a jurisdição estatal moderna.

O texto da lei se traduz em uma "narrativa mestra da nação" de superioridade moral que se consubstancia nos processos históricos de dominação material como a conquista, a colonização e, mais tarde, a espoliação imperialista, de modo a caracterizar um "colonialismo moral” (SEGATO, 2006a, p.212).

Neste sentido, vale dizer que a moral está associada tanto a uma determinada época - baseada na tradição e nos costumes - quanto a um determinado povo - contrato moderno. As leis seriam sistemas que se cruzam com essas questões (SEGATO, 2006a). 
É neste sentido que os direitos humanos passam a tensionar com outros direitos "não somente no caso das sociedades simples ou dos povos originários, mas também no próprio ocidente, em plena modernidade" (SEGATO, 2006a, p. 209).

Nota-se que a genealogia dos Direitos Humanos está vinculada ao tempo e ao território moderno de modo a se consubstanciar no signo da modernidade. Sendo a modernidade o mundo do "um", do "eu" que não tolera diferenças, "outras" revoluções em prol dos direitos humanos foram encobertas.

A esse respeito, Aníbal Quijano destaca que a experiência mais radical da "Era das Revoluções" foi a Revolução Americana do Haiti. Esta foi única revolução do mundo em que ocorrem três fenômenos no mesmo movimento histórico: "La independencia nacional, la descolonización del poder social y la revolución social” (QUIJANO, 1995, p. 9).

De modo complementar, o autor César Baldi expõe:

\begin{abstract}
Por um lado, a Revolução Haitiana (1804), que se torna a primeira nação negra, de escravos iletrados, a se tornar independente e abolir a escravidão e estabelecer, dentre outros, direitos iguais para filhos nascidos fora do matrimônio, a possibilidade de divórcio. Por outro lado, o movimento de Tupac Katari (1780-1781) e Bartolina Sisa, na Bolívia, contra o domínio espanhol, que vai determinar uma profunda reorganização comunitária e a criação de novas formas de intermediação política e mercantil. (BALDI, 2014, p. 1).
\end{abstract}

Conforme o exposto, nota-se que a característica do invariante cultural que ocultou "outras" manifestações históricas de direitos humanos se construiu com base na negação de "outras" realidades e, consequentemente, de "outras" histórias. Logo, a homogeneização das manifestações históricas de direitos humanos travou o saber histórico de outras lutas, resultando no silenciamento da significação histórica de "outros" povos.

De modo a recapitular, a matriz da linguagem colonial dos direitos humanos se instaura tanto pelas vias jurídicas com base nos princípios das correntes jusnaturalistas e juspositivistas quanto na construção e solidificação da memória histórica dos direitos humanos. Trata-se de uma questão epistemológica construída eurocentricamente que excluiu do seu monumento conhecimentos e histórias desde o Sul.

Deste modo, pensar num projeto de expansão dos direitos humanos é um grande desafio que envolve a superação epistemológica capaz de promover uma renovação histórica inclusiva de passados e presentes suprimidos, emancipadora e ativadora de autonomia e autoestima. 
O primeiro passo é notar que os direitos humanos não constituem um discurso homogêneo, não são sinônimos de um consenso, não se reduzem a si mesmos, não encontram na forma da lei sua única representação, não são direitos aprisionados num tempo num espaço geográfico. É importante não perder de vista a negação, a discriminação e o esquecimento de direitos humanos passíveis de serem positivados ou não - incluo aqui a luta por direitos discursivos e simbólicos que produzem uma conscientização social. A positivação é dispensável, uma vez que ela não é sinônimo de garantia. Por esta razão, a proposta que se destaca aqui é de se "pensar nos direitos humanos como um espaço de luta" 48 e um campo para não só reivindicar, mas construir direitos.

Longe de tentar definir esta complexidade que são os direitos humanos, cabe recordar que sua configuração é inacabada, ou seja, está em constante construção. Por esta razão, tais direitos devem ser pensados não como um objeto, mas como um sujeito ativamente histórico, capaz de fomentar mudanças dentro da sua própria construção histórica.

Para que haja expansão dos direitos humanos é fundamental que esses direitos se movam. Para que haja movimento é essencial que exista luta, que, por sua vez, é impulsionada pela insatisfação.

3.4.1 A ética da insatisfação enquanto princípio fundamental para expansão dos direitos humanos

A noção de direitos humanos trabalhada até aqui se desenvolveu a partir tanto do pensamento crítico sobre as correntes jusnaturalistas e juspositivistas adotadas pelos documentos de direitos humanos quanto da ótica crítica referente à memória histórica destes direitos. Como já mencionado, as duas correntes transformaram o ser humano em uma ordenação sistemática.

A memória histórica da nação, ao desconsiderar outras lutas de direitos humanos como a resistência indígena e negra contra os colonizadores, construiu uma concepção

${ }^{48}$ A visão dos direitos humanos enquanto espaço de luta é umas das vertentes desenvolvidas por Herreira Flores (2008). 
singular destes direitos de forma a consolidar uma cultura de reconhecimento, a qual serviu como filtro de histórias consideradas inferiores.

Tendo em vista a grande preocupação que gira em torno da possível expansão dos direitos humanos - que não se traduz em uma única dimensão normativa, tampouco em um único episodio histórico - é que oportunamente versarei sobre a incorporação na conjuntura política dos Direitos Humanos de um terceiro princípio fundamental. Seu posto longínquo, tanto da moral quanto da lei, encontra orientação na ética da insatisfação.

Este princípio construído pela antropóloga Rita Segato surge em contraponto às concepções abstratas. Consiste no impulso ou desejo que promove a contestação da lei e provoca uma reflexão sobre os códigos morais vigentes, servindo como guia para o campo irregular onde é possível desinstalar "os chips que tornam o comportamento automático". Trata-se de um processo que, ao permitir o acesso "do outro lado da consciência", ultrapassa “a visão programada de uma época” sustentada por uma programação cultural e jurídica (SEGATO, 2006a, p. 222).

Essa pulsão, diferentemente das outras correntes, não nasce da abstração, mas de uma ausência notificada pela insatisfação ainda não contemplada no direito. Trata-se de uma tentativa de autoconhecimento fundamental para o redirecionamento da vida e, consequentemente, da nossa própria historicidade, já que somos "plenamente humanos por estarmos na história". Por sermos seres humanos relacionais e ativamente históricos, "não respondemos a uma programação da moral ou da lei" (SEGATO, 2006a, p. 223).

Neste contexto, a ética se traduz na "aspiração ou no desejo de mais bem, de melhor vida, de maior verdade, e se encontra, portanto, em constante movimento". Logo, "se a moral e a lei são substantivas, a ética é pulsional, um impulso vital, se a moral e a lei são estáveis, a ética é inquieta" (SEGATO, 2006a, p. 223).

Ainda sobre as noções de ética, Segato toma como aporte as referências teóricas dos filósofos Nietzsche e Foucault. 0 primeiro, um grande "representante de uma ética contraburguesa e anticonformista" associa, a partir de uma postura filosófica, suas premissas sobre a insatisfação a um estado de luta. Logo, o sujeito ético seria "o ser em movimento, aberto ao futuro e à transformação, o ser exigido por uma vontade infatigável de transmutar valores e minar certezas, o ser que duvida e suspeita". 0 segundo se refere a "uma ética da incomodidade", a qual deveria ser experimentada por 
aqueles sem poder enquanto um "fundamento de uma esquerda essencial" baseada no incômodo das próprias pressuposições (SEGATO, 2006a, p. 224).

A ética não se traduz em um sistema de regras de comportamentos condizentes com os padrões positivados. Muito pelo contrário: por meio do exercício da alteridade ela permite o estranhamento do nosso próprio mundo, fazendo com que revisemos "a moral que nos orienta e a lei que nos limita". Nessas linhas, os indivíduos poderão contribuir eticamente, por meio da interpelação, com o campo da moral e do direito na medida em que se mobilizarem para inserir nestes campos, outras soluções, percepções, moralidades e legislações (SEGATO, 2006a, p. 228).

Desse modo, cabe afirmar que "o motor expansivo dos direitos humanos" só irá trabalhar se calibrado com o anseio ético - ato desnaturalizador de regras que sustentam a paisagem normativa capaz de dar ritmo histórico à moral e às leis. Ou seja, é a ética da insatisfação, constatada "entre os cidadãos de qualquer nação e nos membros da mais simples e coesa das comunidades morais", que constitui o fundamento dos Direitos Humanos (SEGATO, 2006a, p.229).

Conforme a fluidez dessas considerações cabe notar que a lei por si mesma não provoca nenhuma mudança de comportamento, devido ao seu caráter hegemônico. Com efeito, a persuasão, tratada aqui como sensibilidade ética, é fundamental para expandir com mudanças os direitos dos direitos humanos. Esse caminho, orientado pelo impulso, assertivamente situa os direitos humanos na ótica da insatisfação.

A pulsão ética pode ser provocada pela dor. Nessa linha, é importante destacar que não se trata de uma dor física, mas de uma dor íntima que não se reduz a uma expressão de sentimento, já que está atrelada à construção da subjetividade e não a um estado emocional passageiro. Trata-se de uma dor subjetiva que possuiu derivações histórico-sociais capazes de estabelecer um canal de linguagem entre aqueles que se uniram devido a uma dor provocada por uma falta.

No Brasil, a aniquilação na historiografia familiar das memórias das linhagens não brancas fragmentou a construção sobre quem somos. Desconhecê-las é des-saber sobre as nossas origens, é não ter identidade.

Com base neste direcionamento é que o resgate das memórias das nossas origens não brancas se traduz na única forma possível de saber quem se é. A grande questão é de como os direitos humanos poderiam expandir seus direitos de modo a possibilitar a 
devolução da consciência histórica sobre essas linhagens àqueles que, assim como eu, desconhecem sua origem familiar.

Uma das propostas indicadas para o debate compreende a adoção da linguagem da dor pelos direitos humanos sem que haja uma materialização desta linguagem. Neste contexto, a linguagem da dor serviria como um direcionador para o reconhecimento e para a expansão de direitos, já que por meio dela é possível construir direitos que primeiramente são sentidos, depois pensados e discutidos. A referida linguagem seria, para os direitos humanos, uma espécie de gramática não normatizada, mas socialmente legitimada ao ser lida por aqueles que carregam a marca de uma falta que se funde com a história.

A dor é um vocabulário que existe nos direitos humanos para se referir à dor física, a dor material. Entretanto, o ponto-chave para a reflexão é a dor subjetiva. Esta deveria ser problematizada pelo direito não enquanto um objeto metodológico, mas enquanto um elemento intrínseco de construção identitária, que neste caso se inicia com o resgate de memórias.

0 direito à memória não tem fundamento sem que a dor seja considerada, do mesmo modo que não existe identidade sem que haja memória. Por consequência, a memória e a identidade são fenômenos correlatos à dor. Uma sem a outra tornam-se elementos ocos.

A proposta de inserir essa linguagem no âmbito dos direitos humanos a partir desta ótica identitária de base racial poderá abrir caminhos para o reconhecimento de mais direitos e mais histórias.

Essa luta por este direito humano não é uma reivindicação de leis para se judicializar. É, sim, uma luta em prol da nomeação de um direito, nomeação de uma dor.

Diante dessas pontuações, cabe a seguinte indagação: que direito seria capaz, ao realizar uma leitura racial a partir da perspectiva histórica marcada pela dominação colonial, de garantir a devolução histórica àqueles que tiveram a memória de suas linhagens não brancas censuradas? Antes de tentar responder a essa pergunta é fundamental a compreensão dos motivos que corroboraram com a censura dessas linhagens. 


\section{CAPÍTULO 4 \\ O silêncio, a nossa maior herança}

Como mencionei no terceiro capítulo, é no campo de interseção das memórias silenciadas que a minha história começa. Aliás, não só a minha, mas a de inúmeras famílias brasileiras, uma vez que é evidentemente crescente a valorização das linhagens brancas, como as europeias, e o envergonhamento das linhagens não brancas. Devido a esse movimento contrário à realidade brasileira é que as heranças raciais passaram a somar silêncios cognitivos, ocasionando rupturas geracionais construtoras de um vazio hegemônico no que diz respeito às suas memórias.

Este tópico tem como finalidade a construção crítica sobre o esquecimento e a eliminação das nossas origens não brancas, apagadas do registro da historiografia familiar brasileira. Esta censura é vista como um dos motivos que obstruíram o direito humano de saber quem se é.

O bloqueio das linhagens não brancas teve início com a intervenção colonial, a qual apresentou uma nova ordem racista no modo de as pessoas constituírem suas memórias familiares. A mestiçagem compulsória não só física, mas cognitiva, foi utilizada como principal instrumento para a construção de um cenário familiar branqueado. Ela pregava o emblema de que o branqueamento seria a única saída para se tornar civilizado. Deste modo, toda violência colonial era justificada na ideia de civilização do outro.

Desta forma, o projeto histórico trabalhado aqui se refere à mestiçagem como um branqueamento construído ideologicamente. Através dela foi possível sequestrar o sangue não branco, bem como diluir sucessivamente "os rastros do negro e do indígena no mundo miscigenado, no sentido de branquear o continente" (SEGATO, 2012, p. 115).

Nas teias do branqueamento ocorreu o sequestro da memória sobre "quem se era". A família foi um dos principais alvos deste crime, visto que ela era a principal rede responsável pela transmissão da memória.

Sob esta mirada, a concepção sobre família passa a se distanciar da ideia de unidade doméstica passiva e torna-se uma instituição mediadora entre o Estado e a 
sociedade. Logo, é possível afirmar que a estrutura familiar e a nacional mantinham relações estreitas.

Os modelos familiares europeus foram impostos durante o processo de colonização a outros grupos estigmatizados como incivilizados. Os diversos modelos baseados nas especificidades de cada grupo étnico e racial, os quais já existiam antes da chegada dos europeus, foram se deteriorando à medida que a assimilação se ampliava. Vale dizer que a criação deste cenário homogêneo, conduzido pelo processo de assimilação, transformou os modelos familiares num pedaço da nação, num canal reprodutor de discursos hegemônicos.

As famílias, ao se tornarem o aparato ideológico do Estado, se utilizam da figura paternal para fortificar suas relações de poder e autoridade. Como escreveu Joachim Marcus (1949 apud FANON, 2008, p. 128-129):

\begin{abstract}
A autoridade do Estado é, para o indivíduo, a reprodução da autoridade familiar através da qual ele foi modelado desde a infância. 0 indivíduo assimila as autoridades encontradas posteriormente à autoridade paterna: ele percebe $o$ presente em termos de passado. Como comportamentos humanos, o comportamento diante da autoridade é aprendido. E é aprendido no seio de uma família que pode, do ponto de vista psicológico, ser identificada pela sua organização particular, isto é, pela maneira com que a autoridade é distribuída e exercida.
\end{abstract}

Observa-se que a família branca "é depositária de uma estrutura", neste caso, racista, a qual é reforçada pela figura do pai, interiorizada pelos outros membros familiares e reproduzida por estes socialmente. Nesta mesma ótica cabe complementar que "a sociedade é, verdadeiramente, o conjunto das famílias" (FANON, 2008, p. 132).

A constituição da família brasileira carrega o fardo de representar o retrato fiel do progresso. Para que o país se desenvolvesse era necessário que este se tornasse branco tanto fisicamente quanto subjetivamente. A acepção desses haveres incluía o abandono de linhagens não brancas e, consequentemente, o esquecimento sobre quem se é. A filiação passou a indicar a posição de que os membros familiares deveriam ocupar na sociedade. 0 negro e o índio eram sinônimos de riqueza para os senhoriais, uma vez que a exploração e a escravidão ${ }^{49}$ eram lucrativas.

49 "Alguns abolicionistas, como o escritor Joaquim Manuel de Macedo, autor do romance "As vítimasalgozes", defendiam o fim da escravidão não por razões humanitárias, e sim para preservar os brancos da contaminação e da corrupção moral que a presença de negros na intimidade da casa senhoral estaria a introduzir" (SEGATO, 2006b, p. 4). 
Alguns povos indígenas e negros, por meio de estratégias de inteligência superior à do homem branco, resistiram de modo a preservar seus projetos históricos de povo, mas grande parte da população viu no branqueamento a garantia de pertencimento social (SEGATO, 2010).

A mestiçagem etnocida construiu um caminho homogeneizador em direção à brancura capaz de unificar a nacionalidade, o que, de fato, reforçou o esquecimento das linhagens constitutivas. Além disso, por meio da ideia de degenerescência interveio nos projetos históricos originais, embaraçando a continuidade destes.

Por essa razão, a mestiçagem deve ser lida como um vetor resultante da colonização, o qual se impulsionou como "etnocídio" efetuado "por vías de fuerza" autoritárias utilizado, ainda, para "suprimir memorias y cancelar genealogías" (SEGATO, 2010, p. 20-26).

Apesar de ser um projeto colonialista, a censura sobre quais pessoas deveriam ser lembradas - no que diz respeito à constituição de linhagens - foi fortalecida a partir da disseminação de uma consciência historiográfica racista consubstanciada nas teorias de historiadores, médicos e antropólogos que se apoiavam nas teorias estrangeiras vinculadas e legitimadas pela biologia (determinismo científico e racial, como o darwinismo). Estas narrativas formularam a consciência nacional.

A raça se torna o elemento fixador do futuro da nação. No final do século XIX os negros e os mestiços "são apontados como índices definidores da degeneração, ou como os responsáveis pela falta de futuro do país". A cultura racista vai construindo seu "laboratório racial" a partir de discussões sobre miscigenação e a inviabilidade da cidadania (SCHWARCZ, 2013, p. 23).

No início do século XX, surge uma nova ideologia de branqueamento - retificadas nas teses "gilbertofreyrianas", as quais "afirmaban la positividad de la captura secuestro, violación, apropiación, devoramiento - de lo africano y de lo indígena por la codicia y la lujuria portuguesa" - o mito da democracia racial (SEGATO, 2010, p. 40).

Nesta direção, todas as narrativas históricas desenvolvem-se por meio de um exercício regulado para se construir um passado sem falhas, sem a violência racial. Deste modo, a censura da história brasileira apresentava-se como um controle sistemático de conteúdos, informações e ideias referentes ao passado imposto por autoridades.

0 projeto de consciência histórica fundado na mestiçagem é integrado às memórias autoritárias do período colonial e, posteriormente, às memórias ditatoriais. 
Ao serem positivadas, se tornaram memórias oficiais e ditadas como verdadeiras. Todos os canais de disseminação de informação, como livros, músicas, obras de artes (modos de expressão em geral) passam a compor este cenário colonizador em direção à brancura.

Logo, cabe observar atenciosamente que a mestiçagem foi e permanece sendo um apagamento não só da memória histórica, mas da memória do corpo (físico, psíquico e emocional). Diante desse aspecto, o presente trabalho, ao reivindicar o resgate das linhagens não brancas, se direciona para um caminho que se afasta do debate restrito da mestiçagem que se associa a ideias de cores (e não de raça), consubstanciada no mito das três raças (branca, negra e a vermelha) ${ }^{50}$.

Pretendo, ao buscar uma memória que nos agregue à nossa origem, a ressignificação da nossa herança racial a partir de outra compreensão da mestiçagem que não a "política branda produzida pela elite branca e branqueada e sempre colonizadora" (SEGATO, 2010, p. 27).

O presente esforço visa apresentar uma ótica oriunda de projetos históricos latentes e emergentes lapidados não sob um olhar romântico e colonizador, mas sob um olhar subjetivamente real. Como ensina Segato (2010), a mestiçagem deve servir como uma bússola que aponta para o Sul e não mais para o Norte. Somente sob esse olhar é que será possível resgatar histórias perdidas. Não se trata somente de histórias esquecidas, mas de histórias nunca sabidas, como a minha história.

Os brasileiros precisam se conscientizar de que a vergonha e a necessidade que eles sentem de ocultar a nossa ascendência não branca é fruto de uma estrutura ideológica que massacrou, destruiu nosso povo, suprimiu nossas identidades e gerou uma continuidade contraproducente à nossa história.

A nossa história não está engessada, tampouco configura um modelo a-histórico. Muito pelo contrário, ela segue num curso negativo de apagamento da presença dos elementos raciais constitutivos, bem como de seus protagonistas, como a figura da mãe não branca.

50 O primeiro concurso do Instituto Histórico e Geográfico Brasileiro criado em 1844 exigia que os candidatos escrevessem uma redação sobre "Como escrever a História do Brasil". O naturalista estrangeiro Von Martius, defensor de que a história deveria ser construída por meio da mistura de suas três raças, foi o vencedor. 


\subsection{O sequestro da maternidade indígena}

Ainda sobre o apagamento das memórias familiares na historiografia brasileira vale destacar que a mãe indígena recebeu pouca atenção dos historiadores brasileiros. Assim como a babá negra51, as mulheres indígenas integradas ao mundo branco foram excluídas de toda literatura brasileira. Fala-se sobre a mãe mestiça que é fruto de uma relação entre branco e índios ou entre brancos e negros, mas não da mãe índia fora de sua aldeia.

Este sequestro da maternidade se traduz numa apropriação ideológica fundada na mestiçagem, a qual construiu uma imagem estereotipada da figura da mãe que perpassou paradigmas coloniais, nacionais e de classes hegemônicas.

A colonialidade historiográfica, fundada em ideias "higienistas, racistas e patriarcais próprias da modernidade", se pronuncia diante dos dois papéis de pais - o biológico e o jurídico (sobrenome e posses) -, mas é muda no que se refere ao papel das duas mães. Neste sentido, vale colocar em pauta a lacuna relativa às duas formas de maternidade: 1. da mãe biológica e jurídica, geralmente fundidas em uma só; e 2. da mãe e da babá (SEGATO, 2006b). Como expõe Segato: "durante a Colônia e até a segunda metade do século XIX, os serviços das amas-de-leite foram se restringindo lentamente aos de amas-secas ou babás". Este movimento foi consequência "das pressões higienistas exercidas sobre a sociedade nos consultórios médicos e através da imprensa escrita da época" (SEGATO, 2006b, p. 4).

Neste sentido, funde-se na sociedade a ideia de que o leite materno da babá transmitia doenças. 0 olhar para o leite como uma herança de um sangue racializado o transformou em uma via de contaminação afetiva e cultural que tinha como sintoma "o acatamento da modernidade colonial” (SEGATO, 2006b, p. 16).

A partir de então surgiram "propostas de compromisso entre a permanência das criadeiras e os cuidados com sua origem e saúde". Diante de um intenso ódio proferido contra aquelas que doavam todo o seu afeto aos filhos das famílias brancas e

\footnotetext{
51 A antropóloga Rita Segato (2006b), ao pesquisar sobre a presença da babá negra na historiografia brasileira e não encontrá-la, chama a atenção para a dupla negação do gênero e da raça oriunda do olhar "higienista e racista próprio da modernidade".
} 
branqueadas, o seio recomendado passou a ser o da mãe-senhora, o único seio materno branco e limpo (SEGATO, 2006b, p. 4-5).

Diante deste contexto, a mãe passou a ser uma só, como diziam os higienistas, e a babá se tornou o símbolo da prestação de um serviço doméstico, apesar de possuir um forte vínculo maternal.

Em contrapartida à ausência de inscrição no meio acadêmico sobre as maternidades negras e indígenas pode-se citar a história de Malinche, que, para os mexicanos, apresenta ao menos uma ambivalência no que se refere à maternidade. $\mathrm{A}$ mãe Malinche é vista tanto como a mãe índia ilegítima escravizada, estuprada, que ao estreitar relações diplomáticas e sexuais com um estrangeiro foi acusada de trair seu próprio povo, quanto como uma mãe salvadora da nação mexicana por ter iniciado a prática da mestiçagem (SEGATO, 2006b).

O complexo de Malinche também trouxe consequências identitárias para os mexicanos, os quais passaram a se compreender como filhos ilegítimos devido à união dessas linhagens antagônicas (maldição de Malinche). Logo, eles não se demonstram orgulhosos da mestiçagem, pois esta simboliza a derrota, o sofrimento e a humilhação dos vencidos (SEGATO, 2006b).

Sobre essa discussão, é importante destacar que em ambos os casos, tanto a imagem da mãe branca vista como boa mãe e de Malinche que mesmo sendo índia é vista por alguns mexicanos como mãe salvadora, está presente o pensamento colonizado. A primeira define um estereótipo ideal para ordem familiar. A segunda permitiu a entrada de uma ideologia nacionalista de branqueamento. Tanto uma quanto a outra são criações patriarcais e autoritárias. Logo, a boa mãe (construção colonialista) é sempre aquela que simboliza a identidade nacional (SEGATO, 2006b).

Diferentemente do Brasil, que nega as histórias das maternidades negras e indígenas, a narração da história mexicana sobre Malinche não é espetacularizada. 0 exercício do poder colonial, o estupro e a submissão, não são elementos escondidos pela história.

Ainda sobre esta questão cabe a ressalva provocada pela mitologia do Xangô do Recife sobre a duplicidade das duas mães: Yemanjá, a mãe legítima, mãe biológica, e Oxum, a mãe de criação. A primeira é descrita como uma mãe "fria, hierárquica, distante e indiferente", "traiçoeira e falsa como o mar". Tais comentários são na verdade a evocação de uma "traição histórica": o Atlântico, ao trazer os escravos para o Novo 
Mundo, implantou definitivamente sua distância com a África. Trata-se de uma "ambivalência com relação ao mar, que separou no passado, mas liga no presente as costas dos dois continentes" (SEGATO, 2006b, p. 8-9).

Neste sentido, a figura da mãe legítima representa para a tradição "a separação dos vínculos de parentesco dos laços biológicos, o papel do mar na separação da África originária; e a indiferença e a traição do estado" (SEGATO, 2006b, p. 9).

A narração sobre essas duas mães, a "bifurcação" que contempla o enunciado de fala branca e outro de fala negra, se contrapõe à voz do discurso higienista, universalizante e hegemônico capaz de bloquear a "inscrição de sujeitos posicionados diferentemente". Estas duas posições contrárias de fala "sobre o perfil e o valor de cada uma das mães" aponta para o ausente, para a invisibilidade, enfim, para o esquecimento sobre a mãe e a raça (SEGATO, 2006b, p. 12).

As supressões na produção do conhecimento sobre as nossas linhagens maternas não brancas trouxeram consequências psíquicas para toda a sociedade que pairam sobre a violência racista. 0 desconhecimento simultâneo do materno e do racial, a reprodução inconsciente do racismo e da misoginia por aqueles que desconhecem suas origens impactou diretamente na construção de nossas identidades. Os fios que entretinham histórias familiares e davam continuidade ao tecido ancestral foram violentamente interditados (SEGATO, 2006b; 2007b).

Sob a ótica destes silêncios históricos que impactaram na psique nacional é que se aloja o direito humano de saber quem se é. Pensar nesse direito é pensar em todos os elementos que abarcam a restituição identitária. Para se reconstruir uma identidade fragmentada é preciso recuperar a consciência sobre a própria linhagem, impedir que nossos laços de parentesco permaneçam apagados nas nossas histórias de vida, construir e lutar por diversas formas de manter vivo o nosso legado racial.

\subsection{O direito humano de saber quem se é}

Como delineado, o instrumento colonial da mestiçagem foi uma estratégia eficaz para o esquecimento das memórias das nossas origens não brancas. Apagadas também 
da historiografia brasileira, foram arremessadas para o campo das memórias proibidas, pois assim se poderia construir uma nação branqueada não só fisicamente, mas subjetivamente.

Esse legado subjetivo promoveu, sem tardar, abandonos de histórias de vida que interferiram diretamente na compreensão sobre quem se é. A questão da identidade foi reduzida a um desígnio nacional que bloqueou tanto o resgate quanto a construção de novas identidades, inclusive as não disponibilizadas socialmente.

Com efeito, é sobre as complexidades identitárias relativas às questões raciais que envolvem a reatadura das linhagens perdidas, a devolução das consciências históricas àqueles que se viram expropriados e que hoje vivem uma espécie de "orfandade genealógica" (SEGATO, 2010), que se trata o direito humano de saber quem se é.

Esse direito emergente, vinculado ao direito à identidade, encontra seu lar na insatisfação pessoal, na dor, na dúvida e no descontentamento, tendo em vista que a identidade não é espontânea, mas sempre reflexiva.

Vislumbrei em um caso concreto ocorrido na Argentina a possibilidade de realizar uma analogia de experiências como uma aproximação comparativa fundamental para o entendimento do direito humano de saber quem se é, o qual venho reivindicar desde o Brasil. Em ambos os casos é notável a busca pela nomeação de um silêncio provocado pelo autoritarismo Estatal.

0 caso ocorrido na Argentina trata do roubo de bebês ${ }^{52}$ durante o período do golpe militar denominado pelos militares de "Processo de Reorganização Nacional" (1976-1983). Essa ação clandestina operada pelo Estado, baseada em razões políticas, se utilizou estrategicamente do vínculo familiar para exterminar ideologias consideradas contrárias à arbitrariamente imposta. Desse modo, "anular, borrar la identidad y las raíces de estos niños tenía como objetivo que no sintieran ni pensasen como su padres sino como sus enemigos" (MINISTERIO DE LA EDUCACIÓN, 2010, p. 31).

A apropriação ilegal ocorria de três maneiras principais: as mulheres grávidas eram sequestradas e após o parto eram separadas de seus filhos; algumas crianças eram sequestradas junto aos seus pais; alguns pais, sob ameaça, entregavam seus filhos à

52 Cabe destacar que no Brasil as crianças também foram sequestradas, torturadas e presas durante a ditadura militar. O livro Infância Roubada (SÃO PAULO, 2014), publicado pela Comissão da Verdade de São Paulo, Rubens Paiva traz o depoimento de 40 famílias. Este é o primeiro material disponível que abarca esta questão. 
força armada (MINISTERIO DE LA EDUCACIÓN, 2010). Todas as crianças violentamente apropriadas possuíam como destino o abandono familiar, de si e de sua história. A saber:

\begin{abstract}
Los niños y las niñas robados como "botín de guerra" tuvieron diversos destinos: fueron inscriptos como propios por los miembros de las fuerzas de represión; vendidos; abandonados en institutos como seres sin nombre; o dados en adopción fraguando la legalidad, con la complicidad de jueces y funcionarios públicos. (MINISTERIO DE LA EDUCACIÓN, 2010, p. 31).
\end{abstract}

Portanto, essas crianças tiveram suas identidades anuladas, visto que foram privadas de viverem com suas famílias legítimas, de todos seus direitos e liberdades. Assim, foi produzida "una filiação falsa" que retirou destas crianças o direito a "vivir con su verdadera familia, conocer su verdadero origen y su verdadera historia" (MINISTERIO DE LA EDUCACIÓN, 2010, p. 31).

As abuelas de Plaza de Mayo53 - batizadas primeiramente como "Abuelas Argentinas com Nietitos Desaparecidos" - é um grupo de mulheres unidas pela solidariedade, pelo amor e pela coragem que se organizaram para buscar o paradeiro de seus netos e bisnetos (desaparecidos vivos) sequestrados no período da ditadura militar. 0 procedimento dessa busca segue sendo operado por uma equipe profissional interdisciplinar, a qual atua em quatro níveis:

\footnotetext{
en las denuncias y reclamos ante las autoridades gubernamentales, nacionales e internacionales, presentaciones ante la Justicia, solicitudes de colaboración dirigida al pueblo en general y pesquisas o investigaciones personales. En años de dramática búsqueda sin pausas logramos localizar a 115 niños desaparecidos. (ABUELAS DE LA PLAZA DE MAYO, on-line).
}

Esta busca pela verdade transfigurou-se no direito à identidade definido no material educativo "Quien soy yo?", proveniente de uma parceria das Abuelas junto ao Ministério da Educação da Argentina (ARGENTINA, 2010). O conceito de identidade estaria associado a "un proceso que se reafirma y reestructura a lo largo de toda la vida" que é o direito de cada um de saber quem se é (ARGENTINA, 2010, p. 35).

53 A história das Abuelas de Plaza de Mayo encontra-se disponível em: http://www.abuelas.org.ar/institucional.php?institucional=historia.htm\&der1=der1_hist.php\&der2=de r2_inst.php. Acesso em: 07 jul. 2015. 
Seguramente, a construção da identidade se dá no seio familiar, na comunidade, na nação, além de incluir "características como la filiacion (ser hijo de), el gênero, la etnia, las opciones culturales, religiosas y politicas" (ARGENTINA, 2010, p. 35).

Observa-se que a concepção de identidade construída pelas Abuelas se afasta de uma concepção fixista. A identidade é um processo de construção e de reconstrução feita pelo próprio indivíduo e não uma imposição, sobretudo nacionalista. Logo, a formação identitária encontra-se em movimento provocado pela dúvida. Se o indivíduo não tem dúvidas sobre a própria identidade, ele se torna vulnerável às imposições.

A identidade só é verdadeira quando parte de uma reflexão própria. A memória, por sua vez, é o motor da reflexão. No ensaio antropológico sobre memória e identidade, Candau (2012) aborda a dialética da identidade e da memória. Para ele, a memória é formadora de identidade, assim como a identidade é geradora da memória. De fato, existe um reforço mútuo entre as duas.

O meu processo de autoidentificação para com os signos indígenas que herdei de minha avó fez como que eu me questionasse sobre a identidade branqueada, a qual me foi imposta. Foi a partir da dúvida de que meus descendentes não eram somente brancos que decidi resgatar não só a memória da minha linhagem indígena, mas a minha própria identidade.

Ao reconstruir minha identidade a partir deste resgate desobstruí a barreira que a impedia de ser transmitida às próximas gerações. Caso eu ainda estivesse aprisionada no limbo do desconhecimento sobre a minha origem, essa memória familiar indígena se manteria para sempre silenciada. Quiçá o meu sobrinho estaria fadado ao desconhecimento tanto sobre a sua bisavó índia quanto sobre si mesmo.

0 direito à identidade, desenvolvido pelas abuelas como um princípio ético, é uma forma de luta contra o efeito da homogeneidade imaginária que atua como uma denúncia sobre o silenciamento de violações não só de direitos, mas de vidas. Logo, o referido direito resulta como fator fundamental para a recuperação das raízes históricas e para a reatadura dos laços afetivos familiares. Afinal, todos têm o direito de saber e de conhecer sua própria história.

Na mesma direção dessa luta está o Brasil. Contudo, o caso que trato aqui não se remete ao roubo físico resultante de sequelas subjetivas, como ocorreu na Argentina, mas de um roubo inteiramente subjetivo. 
Vale dizer que não se trata de uma separação física entre pais e filhos devido aos sequestros e aos assassinatos ocorridos em períodos autoritários, mas de uma censura subjetiva e intersubjetiva que bloqueou o conhecimento sobre as nossas origens raciais.

Em toda a América Latina houve uma intercepção, por meio do contínuo processo da mestiçagem, do nosso sangue não branco. Histórias de vida que, devido ao signo da raça, foram interrompidas. 0 silêncio do Estado sobre esta violência naturalizou no inconsciente coletivo filiações falsificadas. Os brasileiros, ao se afirmarem brancos, estão também atestando que suas linhagens são brancas, o que de fato é uma falsa certificação.

Essa apropriação estatal efetuada por meio de atos de silenciamento e de omissão deixou marcas de interdição em nossas maneiras de amar, de nos relacionar e de pensar. Nossos corpos descansam sobre o anonimato, enquanto nossa equivocada identidade branqueada nos acorrenta na ignorância "de ser quem não se é".

O ponto em comum do caso concreto da Argentina e do Brasil é o esquecimento forçado provocado pelo Estado a respeito das nossas identidades. Nos dois casos, a memória produtora de identidades é construída sobre uma ausência proveniente da falsificação.

Deste modo, poder-se-ia dizer que no Brasil houve uma falsificação da filiação racializada, quando se tentou branquear fisicamente, culturalmente e subjetivamente, inicialmente os povos conquistados e posteriormente toda a sociedade? $\mathrm{Ou}$, ainda, tratase de um caso de ocultação da referida filiação?

Assim como no caso de roubo de bebês argentinos, a situação forçada de orfandade deu-se, no Brasil, pelos dois modos. 0 processo de falsificação teve início quando fomos compelidos a negar nossas origens em face de um projeto civilizatório. Primeiro houve a redução do sentido "de ser na história" - ideia de degeneração dos povos do Sul. Posteriormente, a falsificação alcançou os laços sanguíneos e se utilizou da ocultação, da negação e da substituição subjetiva das identidades brancas de parentesco pelas não brancas ${ }^{54}$.

O Brasil se olha no espelho e se vê branco. Não nos reconhecemos em nós mesmos. Somos uma falsificação de nós porque não temos memórias sobre as nossas origens. Neste sentido, a falsificação identitária sustentou-se por meio de uma mentira

\footnotetext{
540 desenvolvimento desta reflexão encontra lugar na minha experiência familiar. 0 meu pai e os meus tios primeiro foram convencidos de que poderiam construir uma identidade branqueada. Então, falsificou-se quem se era. Depois, falsificou-se a nossa linhagem indígena por meio da ocultação.
} 
de que o Brasil é um país luso, e sustentar uma mentira é naturalizar o desconhecimento.

Os brasileiros estão inconscientemente confinados "en un 'otro' social designado por la atribución racial" (SEGATO, 2007b, p. 139). Temos um enorme e urgente problema de privação da memória familiar que resultou em violentas fragmentações identitárias geracionais.

Discorrer sobre o direito humano de saber quem se é requer uma luta contra a deslegitimação, desvalorização e obstacularização das memórias familiares não brancas. Trata-se de um caminho que busca interromper a pedagogia nacional do silêncio, bem como interpelar a nós mesmos, a sociedade e o Estado sobre o nosso legado racial. É um exercício por justiça que reclama à ordem estatal um direito por conscientização sobre quem se é.

\subsection{Memórias emergentes de um passado presente}

As linhas teóricas da memória e a produção do sentido da memória foram construídas a partir de uma perspectiva teórico-histórica europeia. A ascensão das reflexões teóricas sobre a memória ocorre a partir do evento denominado de holocausto judeu.

Por esta razão, os estudos sobre a memória perseguem a ideia de dever. São estudos que caminham no sentido de busca por uma justiça capaz de quebrar o silêncio pós-guerra, bem como de impedir tanto o esquecimento das vítimas ${ }^{55}$ desconhecidas ou ignoradas quanto a repetição deste tipo de barbárie.

Neste sentido, a história da humanidade se concentra na visão de uma memória do "sujeito teórico" (SPIVAK, 2010) e histórico, qual seja, a Europa56. Esta relação íntima

55 Como explica Hartog (2012), o status de vítima traz consigo a releitura de certos episódios da história. Tal status está atrelado à visibilidade e não necessariamente ao vitimismo. A memória que possui como ponto central as vítimas se converte em um novo campo de "ação política internacional": o de "políticas da memória".

56 Como visto no capítulo 1 e 3, a história se fez no mundo ocidental. A Europa era a única representação da história da humanidade. As sociedades colonizadas eram compreendidas como a-históricas. A nossa 
entre a construção da memória e o Estado moderno produz uma pedagogia da temporalidade, a qual se subscreve na teoria moderna de que o tempo é sucessivo e que para se fazer história é preciso seguir um tempo linear. Consequentemente, a linearidade se transforma no tempo do Ocidente.

Essa visão cronológica sobre o tempo insinua a ideia de que é preciso recorrer ao passado para constituir uma história evolutiva. Vale dizer que a concepção moderna sobre o tempo passado segue um ordenamento homogêneo que ocultou diversos projetos históricos, principalmente quando estes se referiam aos sujeitos e às histórias marcadas pelo signo da raça.

A modernidade não tolera diferenças, ela representa o mundo do "um". Por essa razão, a memória tem se tornado uma "arma", um "duelo" que fala sobre a história dos vencedores e não das vítimas, dos esquecidos, tampouco dos dominados e colonizados. É uma memória de caráter oficial que se encontra aprisionada no tempo do Estadomoderno (HARTOG, 2012).

Sob este prisma, quando o estudo da memória se refere ao "outro" colonizado, este é sempre situado no passado, uma vez que seu signo racial simboliza um atraso temporal. Por mais que a Europa tenha feito história ${ }^{57}$ a partir do massacre e da fundação da América, abordar memórias desde o Sul significa retroagir a um tempo passado que não pressupõe um passado moderno.

Esse binarismo temporal entre a modernidade e o tempo dos outros povos tidos como subalternos reduziu as histórias coloniais, acusadas de não terem evidências históricas, a um mito. Vale mencionar que a modernidade, ao impor um tempo histórico singular e homogêneo, se converteu em um "espaço silencioso de referências" sobre outras histórias (RUFER, 2010, p. 14).

A abstração dessas diversas temporalidades nos territórios colonizados expurgou da história da humanidade as histórias e os sujeitos históricos considerados subalternos. Tal expurgo foi utilizado como tática para a domesticação do tempo.

alienação historiográfica deve-se a este aprisionamento de que somente os vencedores eram detentores de histórias racionais.

57 Como explica o historiador Mario Rufer, era necessário ressaltar o primitivismo para que se construísse a modernidade. Outras temporalidades históricas, como a africana e a latino-americana, ao mesmo tempo em que eram mostradas não coexistiam com as sociedades capitalistas que eram o único projeto possível da modernidade (RUFER, 2010). 
A configuração do "presentismo", digo, "o presente do capitalismo e da globalização", aprisionou o passado num "presente eterno", de modo a privilegiar uma relação imediata rodeada de noções e conceitos "destemporalizados". Os efeitos dessa crise temporal impactaram tanto na "capacidade de inteligibilidade do pensamento histórico" quanto na capacidade de elaboração de "ações transformadoras", uma vez que os tempos das sociedades ficaram confinados a um presente e a um futuro definido. Logo, sem aberturas (HARTOG, 2012, p. 17-18).

Em suma, a concepção sobre o tempo passado pressupõe uma separação entre histórias e sociedades, dado que segue um fluxo histórico singular, um processo investigativo histórico moderno, o qual excluiu de sua temporalidade as demais experiências.

Entretanto, cabe observar que o tempo é heterogêneo. Logo, o passado, o presente e o futuro também os são. Cada sociedade, cada povo tem sua teoria sobre o tempo. No Brasil, os povos indígenas que não sofreram assimilação em sua totalidade conseguiram preservar seus próprios modos de rememorar. Portanto, não espelham seus modos de construir memória nas narrativas do tempo moderno.

Além disso, há que considerar que dentro da mesma nação existem povos que possuem uma noção própria sobre o tempo e povos que vivem a concepção de história moderna sobre o tempo. Estas são narrativas construídas a partir de uma razão histórica, de uma evidência científica. Sob este foco, salienta-se que em uma única nação existem diferentes temporalidades sobre o passado.

A história-nação é responsável pela formação da consciência nacional. Por esta razão, ela opera politicamente como um filtro capaz de marginalizar formas intercorrentes de se inscrever experiências no tempo, ou seja, atua como um lócus de censura de enunciações políticas (RUFER, 2010).

Neste sentido, o uso das temporalidades pela história-nação serve "como una operación política de génesis histórica” (RUFER, 2010), que toma para si uma memória positiva, globalizante e explicativa que melhor lhe constitui. Esta será posta como memória verdadeira (NORA, 1993).

0 vínculo entre história e verdade é compreendido pelo historiador Mario Rufer como "un vínculo de autoridad y autorización", que consolida "un orden histórico de continuidad". Ao partir de uma crítica sobre a hierarquização de sujeitos, culminada sob uma perspectiva pós-colonial, o autor ensina que é importante notar, neste embate entre 
as histórias universais e as histórias marginalizadas, a continuidade violenta de produção e reprodução da história que separa as comunidades não modernas das modernas. Ainda destaca que este processo contínuo atua como uma estratégia política que configura o apagamento das diferenças (RUFER, 2010, p. 21).

Pode-se inferir, então, que as memórias da nação são a tradução de histórias autoritárias travestidas de "efeitos de verdade" 58, que são, na realidade, "efeitos de poder". 0 espectador dessa arena, orgulhoso do espetáculo sobre políticas da memória, não percebe que as memórias oficiais representam "o império, o capital, o nacionalismo", visto que elas ocultam o armamento "político de enunciação" racista, ao se anunciarem socialmente enquanto celebrações (RUFER, 2010, p. 21-22).

As celebrações carregam em seu conteúdo um passado glorioso e, portanto, marginalizador. Trata-se de um passado sem lacunas e sem falhas que, ao se estabelecer no presente e ao se projetar para o futuro, leva consigo as correntes coloniais aprisionadoras de memórias que não as dos vencedores.

Ainda sobre esta questão, Rufer discute sobre a relação entre as concepções do tempo, articulações estatais e ordenamentos políticos da memória:

\footnotetext{
Que noción de tiempo sería necesaria en un contexto poscolonial, latinoamericano, para dar cuenta de todo lo que ese espacio silencioso de referencia (la nación bajo la tutela del estado, el estado- nación) convirtió en historia y sepulto como forma específica de conocimiento - memoria? (RUFER, 2010, p. 12).
}

Sobre este aspecto, vale retomar a análise realizada nos capítulos anteriores sobre a falta de uma concepção sobre a memória referente ao que o historiador Daniel Feierstein (2008), ao estudar as formas de genocídios modernos ${ }^{59}$, denominou de genocídio colonialista. Não existe uma memória sobre o extermínio e sobre as violações de direitos humanos contra os povos indígenas efetuados pela colonização. Os conquistadores não são compreendidos socialmente como genocidas, mas como "heróis". A história sobre o sofrimento e dominação colonial não tem espaço, tampouco nome. Ela segue marginalizada pela história nacional e internacional.

58 Termo utilizado por Michel Foucault ao discorrer sobre história.

59 Para Daniel Feierstein (2011), o genocídio moderno é pilarizado por quatro tipos de aniquilamento: o genocídio constituinte, o genocídio colonialista, o genocídio pós-colonial e o genocídio reorganizador. 
A temática desenvolvida ao longo deste trabalho relaciona-se ao resgate da consciência sobre a verdadeira história colonial. A censura sobre este capítulo da história alcançou o inconsciente coletivo, branqueou a nossa memória, não deixou rastros sobre quem somos. Vale dizer que quando uma experiência como a etnocida é diluída, as identidades também o são.

Segundo Pollak (1989), a função do não dito é de impedir a contestação, a reivindicação e a escuta. Quando o inconsciente coletivo estiver completamente reprimido se alcançará um esquecimento definitivo.

A memória sobre quem somos trata-se de uma memória coletiva. A compreensão que o indivíduo tem sobre si possui uma articulação histórico-social. Esse tipo de memória coletiva se difere da memória coletiva oficial, que atua de forma impositiva mediante "uma forma específica de dominação ou de violência simbólica", visto que ela associa-se a uma adesão afetiva que possuiu como finalidade a identificação e a reconstrução do tecido social (HALBWACHS, 2004).

A seguir, serão expostas as mazelas dos dois usos mais comuns da memória: o modelo historiográfico e o modelo museológico. Ambos são modelos modernos de celebrações não espontâneas da memória. A finalidade do próximo tópico é de demonstrar, por meio de casos concretos, que além de possuírem um significado que provém de uma natureza política seletivista, os modelos modernos de rememorar ameaçam a existência de outras formas de memórias inconciliáveis a esses modelos.

\subsubsection{Os contratempos da historiografia}

A historiografia é uma forma moderna de lidar com passado que detém regras de operação e protocolos científicos. No mesmo seguimento, os museus nacionais servem não só como representações históricas no espaço público, mas como aprisionadores de memórias neste espaço. Portanto, os tipos modernos de se rememorar possuem como foco principal não a memória vivida, mas a memória que não deve ser perdida, e esta é sempre uma memória historicizada.

Para o historiador francês Pierre Nora, a historiografia é cristalizada, positivada e não cumulativa, tradicional, arquivista, um culto documental que não possui 
identificação com a memória, mas com a "nação-memória" enquanto um dado que preserva integralmente o passado por meios de técnicas por vezes abusivas. Este modelo toma para si o "papel diretor e formador da consciência nacional", de modo a se transformar em um "dossiê cada vez mais prolífero", como se devesse "tornar-se prova e não se sabe de qual tribunal de história" (NORA, 1993, p. 9-11).

Neste sentido, os arquivos, por exemplo, atuam como uma "disposición legisladora" que presta "autorización para la narrativa". São pontos de partida para "trair o passado" 60. Logo, o arquivo não é aquele documento oficialmente institucionalizado ou privado, mas uma "disposición moderna de monumentalizar" e de conservar tanto as evidências quanto a "fijación posmoderna de las políticas de patrimonio" (RUFER, 2011, p. 23-24).

De modo a esclarecer, Rufer (2011) recorre ao caso concreto das culturas bantu ou banto. Segundo ele, tais culturas não existem de forma pura, mas a partir da mestiçagem com as sociedades ocidentais. Contudo, a evidência documental não se dá conta sobre o processo de hibridez na significação do passado, fazendo com que esta realidade oscile entre as fronteiras do testemunho e do relato oficial, entre uma verdade do real e a verdade ficcionista da experiência real.

Ao expor este relato etnográfico, Rufer visa chamar a atenção para a noção de autoridade e de autorização da linguagem da memória que, habitualmente, são reduzidas à materialidade dos memoriais como "una gestión del pasado para tutelar el futuro". Logo, é condenada ao tempo da potência do capitalismo que impede os sujeitos "subalternos" de falarem sobre si mesmos (RUFER, 2011, p. 17).

Como já assinalado, quem detém o monopólio para ditar o passado através dos registros da história e da memória é o "sujeito teórico", que compete à figura do Estado. O Estado de hoje é ideologicamente herdeiro dos Estados que instauraram a colônia mediante a conquista da América, e seus sucessores são as elites mestiças brancas e branqueadas (SEGATO, 2007a).

Vale dizer que a linguagem historiográfica brasileira exprime a razão branca e branda. Basta refletirmos sobre as experiências e os sujeitos marginalizados da nossa história (índios e negros), bem como o quanto os sujeitos lembrados, como exemplo, o mestiço, foram utilizados como objeto de reprodução de um discurso racista.

60 Termo utilizado por Jacques Derrida. 
Sob esta ótica, cabe enfatizar que a historiografia - instrumento oficializador do poder do império desde o século XIX - destina-se a reforçar a posição histórica racializada daqueles que permanecem fora da história. Isto é, no âmbito historiográfico existe uma tensão entre as memórias dominantes e fragmentadas ${ }^{61}$. Estas, caso não sejam resgatadas e reconstruídas, correm o risco de permanecerem naturalizadas historicamente em sua invisibilidade.

\subsubsection{As contrariedades da museificação}

A museificação não se difere da historiografia. Oportunamente, cabe destacar que o primeiro complementa o segundo. 0 museu dispõe de narrativas legitimadoras do projeto Nação. São lugares institucionalizados que, além de conservar e exibir peças, alimentam discursos expositivos que expressam como uma sociedade deve ser vista perante olhos internos e externos e de como ela projeta o passado no presente perante uma visão global.

Neste sentido, uma das principais funções do museu é a configuração de ordens simbólicas, bem como a legitimação de espaços de representações oficiais sobre as frentes da história nacional.

A classificação, a conservação e a exibição de objetos buscam garantir um território unitário, bem como o controle retórico da diversidade. Nestes processos, os museus vão separando o desejável do indesejável, privilegiando umas vozes e subordinando outras (MARÍN; CAIRO, 2013).

Com o objetivo de problematizar o museu como um lugar institucional, organizado a partir da Memória-nação, os autores Marín e Cairo (2013) exploraram dois casos ocorridos na Colômbia. 0 primeiro remete-se ao guerrilheiro Tirofijo e o segundo aos ecomuseus referentes às comunidades indígenas das selvas do sul do país.

O caso sobre a toalha vermelha da discórdia é um grande debate sobre os limites da representabilidade. 0 guerrilheiro de esquerda e líder das Forças Armadas

61 Os registros sobre a verdade das violações de direitos humanos efetuadas no período da ditadura militar só ocuparam um lugar no arquivo nacional após a criação da Comissão Nacional da Verdade. Contudo, nem todas as experiências que envolvem violações de tipo constam neste arquivo. 
Revolucionárias da Colômbia (FARC), chamado Tirofijo, costumava usar na maior parte do tempo, sobre um dos ombros, uma toalha vermelha. Após a sua morte, a diretora do Museu, Elvira Cuervo, ao conceder uma entrevista ao jornal diário, demonstrou interesse em adquirir a referida toalha sob o argumento de que o Museu Nacional da Colômbia deveria recoletar a história contemporânea do país e que Tirofijo era parte dela. A iniciativa era transformar a toalha em um emblema de reconhecimento simbólico entre os colombianos sobre uma guerra interna com várias décadas de duração (MARÍN; CAIRO, 2013).

Apesar de ser acusada de terrorista e de receber diversas ameaças, Elvira insistia na importância de transcender a visão do museu. Defendia a ideia de que o Museu não deve ser exclusivamente peças de culto e de glorificação da nacionalidade, mas um local que possibilite a reflexão sobre as dificuldades e épocas que o país atravessou (MARÍN; CAIRO, 2013).

Contudo, as relevantes justificativas de Elvira não convenceram grande parte dos cidadãos colombianos, que permaneceram contrários à representação histórica que este objeto carregava quanto à raça (camponesa) e seu posicionamento político (esquerda). Além da advertência social, o sistema de significados inseridos na toalha foi exonerado pelos setores públicos. Essa indisposição caracterizou o que os autores Marín e Cairo (2013) denominaram de moralização do objeto.

Outro interessante exemplo sobre a maneira em que operam a museificação da memória são os ecomuseus, definidos como museus baseados na comunidade ou projetos de patrimônio que favorecem o desenvolvimento sustentável. Tais museus funcionam como uma representação essencialista e a-histórica sobre as culturas indígenas, uma vez que estão fundidas no projeto colonial constitutivo da modernidade ocidental. Logo, atuam como um poderoso mito do pensamento colonial que evoca a metáfora do bom selvagem para modelar e legitimar as políticas de integração e a violência simbólica estatal (MARÍN; CAIRO, 2013).

Essa visão romântica impacta na maneira como o Estado colombiano se relaciona com as minorias étnicas indígenas desde a década de 1980. 0 Estado dita o papel que os indígenas devem desempenhar, traça planos de desenvolvimento regional em seus territórios, por vezes, sem consultá-los, e ainda administra os recursos de áreas protegidas. Além disso, impõe regras no tocante à intervenção do meio ambiente como princípios de conservação forjados no Ocidente. Logo, o modelo tradicional de produção 
indígena se transforma em paradigmas econômicos do sistema capitalista (MARÍN; CAIRO, 2013).

Cabe destacar que a configuração dos territórios indígenas como ecomuseus oculta as estratégias de sobrevivência de várias comunidades indígenas, ao mesmo tempo em que apaga a memória sobre os séculos de exploração dessas comunidades. Portanto, tende a reduzir "as expectativas destas comunidades a uma vida fora da história detida no tempo do bom selvagem" (MARÍN; CAIRO, 2013, p. 83).

Vale denotar que alguns modos de museificação, mesmo os que visam valorizar as diferenças culturais, correm o risco de essencializar a figura, a história e os modos de vida de povos distintos. Isso é o mesmo que petrificar as alteridades étnicas da região. Significa aprisionar todas as sociedades num passado primitivo (MARÍN; CAIRO, 2013).

Ainda sobre esse tema, ensina Rufer (2010, p. 19) que "los museos nacionales de principios de siglo XX se constituían en políticas atávicas no de la memoria, sino de la distancia". No Brasil existem cerca de 2.700 museus, sendo que grande parte foi construída a partir da segunda metade do século $\mathrm{XX}$, o que comprova as influências modernas no ato de rememorar.

Outro exemplo, relacionado às falências dos modelos modernos de se rememorar é o caso em que é solicitada à Corte Interamericana de Direitos Humanos a construção de uma "efígie para recordar a Germán Escué" - um indígena assassinado pelo exército. Contudo, nem o advogado nem a Corte se atentaram para os equívocos desta reivindicação. Para o povo indígena NASA, monumentalizar seu herói seria o mesmo que matá-lo. Para que a memória dele permanecesse viva era preciso não materializá-la. Este é mais um exemplo da vitalidade do não liquidado pela memória (SÁNCHEZ BOTERO, inédito, p. 15).

Diante dessas contextualizações, cabe notar que o problema das memórias em se tornarem documentos ou monumentos enrijecidos em papéis e esculturas, além de representarem um segundo atestado de morte, também apresentam outras mazelas:

- A vulnerabilidade da representatividade da memória, já que o discurso manipulador se esconde em suas formas rígidas ${ }^{62}$.

\footnotetext{
62 Algumas memórias acabam servindo à gestão estatal, mesmo quando são proferidas por vozes de vítimas. Ao visitar alguns museus no Brasil sobre a ditadura militar, notei que nem todas as vítimas do regime militar possuem um espaço reservado nestes lugares. Os indígenas, os negros e os homossexuais, por exemplo, permanecem à margem desta história.
} 
- A ideia de que a evocação da memória está sempre associada a alguém ou a algo que já se foi, que esteja morto (este ponto sobre os mortos como único objeto da memória será debatido no próximo tópico).

Ambas as formas modernas, discutidas aqui, de se rememorar se complementam de modo a criar um sistema colaborativo de "mundanização, democratização, massificação e mediatização" que compõe uma estrutura social classificadora de memórias (NORA, 1993, p. 10).

Esse sistema implica o engessamento de lembranças; a fixação por vezes deslegitimadora do passado, uma vitrinização que ao resgatar o passado constrói um elo com o presente, sem que seja criado qualquer tipo de vínculo além do material (consulta). É um sistema que manipula, interdita e fragmenta memórias.

\subsubsection{A manipulação da memória}

A manipulação da memória é guiada de acordo com o contexto político do país, que se utiliza de estratégias para construir um projeto nacional. Marín e Cairo (2013) justificam o protagonismo e o abuso da memória sob o argumento de que a memória acompanhou a emergência dos Estados e dos relatos nacionais, como um plano de representação e coesão de comunidade política.

Pode-se dizer que o objetivo da manipulação, ao proporcionar um esquecimento sobre a verdade histórica, forja a identidade coletiva. 0 processo de forjamento se inicia a partir da seletividade dos fatos que podem ser inteiramente ou parcialmente modificados pelo detentor do monopólio do poder sob a memória. No Brasil, por exemplo, não temos uma memória que se remeta ao massacre da conquista. 0 descobrimento do Brasil é visto positivamente pela população como um ato heroico dos portugueses.

0 outro lado da manipulação direciona-se ao acesso à memória como, por exemplo, a falta de visibilidade - uma barreira em relação ao acesso. Novamente tomo o Brasil como exemplo. Os relatórios, os filmes e os depoimentos sobre a ditadura militar 
são ocultados pela grande mídia. Além disso, não compõem o currículo escolar. Essa falta de visibilidade reforça versões ficcionistas que narram apenas um lado da história.

Ainda sobre a alteração do passado, Candau, ao se utilizar do conceito de Pierre Nora, define este processo como uma "economia geral e gestão do passado no presente" (CANDAU, 2012, p. 165). Cita como exemplo a obstacularização da consulta de documentos relativos ao período da Ocupação e deportação de judeus, visto que os arquivos foram administrados de forma virtual, logo, "não se convertiam em memórias objetivas a não ser quando lidos e compreendidos".

Cabe notar que a falsificação da memória alcança todas as sociedades. Ela é uma prática exercida desde a Antiguidade.

1. A memória da Guerra do Peloponeso; 2. A memória dos massacres de junho de 1848 em Paris; 3. 0 monopólio da manipulação legitima dos textos pelos chefes de instituições e facções seculares e eclesiásticas do século XI na Europa $^{63}$ (marco de falsificação da memória institucional); 4- Manipulação da memória dos arquivos em toda a Europa entre os séculos IX e XI, o qual "influenciou largamente a interpretação que as gerações seguintes fizeram desse período"; 5- Destruição de lugares santos ou sagrados como forma de manipulação brutal da memória como ocorreu na ditadura franquista na Espanha; 6- 0 incêndio provocado (devido o conflito entre os judeus israelenses e os palestinos) nas plantações de árvores, as quais simbolizavam a nação judaica e que podem receber nome de pessoas ou grupos desaparecidos (como vitimas do holocausto) demonstrou a tentativa de destruição desta memória; 7- 0 conflito na ex-Iugoslávia e na África, na região dos Lagos em que o esquecimento da história objetivavam finalidades nacionais ou de etnogênese de essencializar e naturalizar identidades; 8- No Brasil "a manipulação da memória pelos brancos consiste em manter a memória da escravidão, pois está é concebida como um meio de inferiorizar os negros, construindo uma identidade americana ou euro- americana com lembranças afro. "; 9- Na França, "a lembrança da repressão à manifestação argelina de 17 de outubro de 1961 é amplamente ocultada, sem dúvida porque este acontecimento pode manchar a imagem de um país democrático e republicano". (CANDAU, 2012, p. 165-167).

Em todos esses contextos a memória foi tratada como um objeto de estudo da história. Todo objeto de estudo é conduzido por uma ordem que irá determinar o que é aceitável ou não (CANDAU, 2012). As memórias, ao serem arremessadas nesse limbo seletivo do que deverá permanecer ou não na humanidade, comportam uma ordenação política da história marcada por uma estrutura racista e misógina.

63 As lembranças "litúrgicas, as estruturas de propriedade fundiárias, heranças, transmissão de sobrenomes entre parentes e nas alianças políticas e sociais" foram falsificadas com o intuito de "forjar uma nova identidade individual e coletiva coerente com as estratégias de poder." (CANDAU, 2012, p. 165). 
Assim, a gestão de forjamento da memória possuiu como grande alvo as formações identitárias, visto que o gênero e raça são lugares de identidade. Assim, quando a autonomia da memória é manipulada ou negada, fatos inverídicos interferem diretamente na consciência sobre o quem somos.

As memórias espelhadas em dores e sofrimentos inegociáveis clamam por transformação, não por concordância sobre um passado. São memórias que estão em movimento e por esta razão, se conservadas forem nas pedagogias atuais da memória, se reduzirão a um exercício retórico. Essas memórias precisam ser nomeadas, mas não necessariamente positivadas. Elas necessitam de liberdade para permanecerem vivas.

\subsection{Em busca de uma memória viva que nos conecte à nossa origem}

Conforme foi anteriormente mencionado, a discussão central deste trabalho refere-se ao resgate da memória das nossas linhagens não brancas. Esta memória encalçada nos campos etnográficos não se encontra dentro dos processos de gestão e de produção de sentido modernos sobre o passado dos mortos. Aliás, ela não é uma representação dos mortos. Ela é um instrumento de resgate sobre a consciência do que está deveria estar vivo em nós.

$\mathrm{Na}$ época que fiz o colegial eram usuais os passeios culturais, entre eles a visita aos museus. Os professores ficavam encarregados de reunir as turmas, reservar ônibus e muitas vezes alguns se tornavam até guias. Antes mesmo que descêssemos do ônibus, todas as turmas ouviam as mesmas instruções: "Não ria, não grite, não chore, não toque. Tomem cuidado! É só para olhar". Enfim, as recomendações dos professores eram: "não manifestem qualquer tipo de emoção ao entrar no museu". Logo, "não tentem estabelecer qualquer tipo de contato até mesmo o físico". E ainda, "assimilem o conteúdo e se sairão bem na escola".

Esta foi uma das lembranças que contribuíram para o meu entendimento de que o museu era um local de frieza que guardava lembranças intocáveis. Contudo, ir até lá me proporcionaria um adensamento cultural, me deixaria automaticamente mais culta. Não me dei conta de que ficaria mais culta sobre as diversas inverdades históricas (como 
a da conquista) e extremamente ignorante no que diz respeito à história do meu país, já que as verdades históricas não estavam comportadas ali.

Ao relatar essa experiência, almejo dizer que por muito tempo fomos ensinados que o museu era um local para que se conhecesse a história. Sim, mas a história que sob a ótica de um Estado racista. Além disso, as limitações impostas para "o conhecer" envolviam um aprisionamento de si mesmo nas grades não tão fictícias, as quais envolviam as memórias. Durante a nossa educação fomos obrigados a aceitar essas memórias, bem como seus modos de imposição como preceitos bíblicos que não deviam ser questionados.

Cumpre reforçar que até hoje não temos no Brasil museus sobre o massacre da conquista, nem da escravidão indígena, tampouco sobre os homicídios e as torturas contra os indígenas cometidos no período da ditadura militar.

Diante desse silenciamento nacional, chamo a atenção para o problema que é reduzir a compreensão de memórias à intelectualização que possui uma única finalidade: (des)informar e/ou distrair. A memória intelectualizada repele a memória sentida. A primeira é um conteúdo material e a segunda é um conteúdo inteiramente ligado à construção subjetiva, visto que compõe o processo de consciência sobre si mesmo.

Por essa razão, ao refletir sobre a representação da memória da minha avó índia - que não se refere a ela particularmente, mas ao processo etnocida provocado pelo autoritarismo colonial, o qual, mediante a implantação de uma ideologia de branqueamento (mestiçagem) censurou as memórias das linhagens não brancas - busco caminhos políticos que sejam capazes de devolver a consciência sobre o que nós, brasileiros, somos.

Não se trata de reivindicar a devolução de uma memória particular. Reclamo, através da minha própria história, a nomeação de uma memória coletiva sobre as nossas histórias sequestradas.

A partir desta mirada cabe destacar, em primeiro plano, que a morte é um elemento dispensável para se garantir a memória. Ela é o principal critério que autoriza a construção de uma memória. Não existe uma memória sobre alguém ou sobre algo que está vivo.

O conceito que desenvolvo aqui sobre memória viva está atrelado ao "que está vivo" e não ao fato "de tornar viva uma memória morta", como se verifica por vias de 
acesso institucionalizado da memória (como filmes e exposições em museus). A memória viva é aquela capaz de despertar a consciência sobre quem somos; as outras memórias são variantes da morte.

A memória a qual discorro sofreu censura, porém nunca morreu. Logo, nem toda memória sobre o passado está morta. Existem memórias de mortos que estão vivas, não porque foram monumentalizadas ou arquivadas, mas por estarem em nós. Refiro-me aos signos que carregamos em nossos corpos. Nossos signos são heranças memoriais capazes revelar e comunicar uma origem familiar (SEGATO, 2007b).

Diante disso, a memória responsável pela devolução da consciência sobre quem somos não é passível de uma redução arquivável ou expositiva, tendo em vista que ela é o elemento constitutivo de nossas identidades e serve como uma cartografia para construção de quem se é. Trato aqui de uma memória que instrui o "deixar-se conhecer". Justamente, seu dever não é apenas informar sobre o passado, mas reconstruir subjetividades.

Esta memória, assim como qualquer outra, exige um lugar de enunciação não fixo, tampouco institucionalizado, pois, como já destaquei, ela se refere a um complexo capítulo sobre memórias subjetivas atreladas à raça. Sendo assim, não se trata de um lugar abstrato e material que "pare o tempo", que "materialize o imaterial" que se confunde com os lugares de história oficiais e que espera "por novos esquecimentos e novas reencarnações". Trata-se de uma memória capaz de repelir este ciclo aprisionador de memórias que é em sua totalidade o simbolismo "da ausência absoluta de vontade de memória” (NORA, 1993, p. 23-25).

A "vontade da memória" atrai a ideia de um anseio sobre o conhecimento da verdadeira memória e não da verdadeira história - que, como foi pontuado, é denominado de verdadeira por quem detém de seu monopólio (nação) -, mas na verdade, ela é apenas oficial. É importante frisar que a característica da oficialidade não se confunde com a verdade.

Sobre esta discussão, Pierre Nora acrescenta que "se ainda habitássemos nossa memória não teríamos necessidade de lhe consagrar lugares" (NORA, 1993, p. 8). 0 ato de habitar a própria memória está, então, atrelado à consciência sobre algo que está dentro de si. Se, inconscientes, seremos meros fantasmas de nossos lugares de memória.

Vale dizer que a chave da verdade está em nós. Carregamos em nossos corpos (lugar de memória) signos raciais que são memórias. Contudo, mesmo que estes signos 
sejam nítidos, a inconsciência sobre si mesmo, a impede de identificá-los. Digo, a nossa memória corporal sofre de uma hipermetropia racial, pois carregamos heranças raciais (signos) desde o nosso nascimento, mas não os enxergamos nem quando estamos diante de um espelho. Logo, o corpo só se sustentará como um lugar de memória se houver consciência. E ter memórias que habitam em nós não é o suficiente quando estamos vendados por uma história ardilosa.

Para realizar este exercício de se olhar no espelho, reconhecer e identificar os signos raciais presentes no próprio corpo, é preciso ter um olhar descolonizado sobre si mesmo. Para ter este olhar é preciso desejar saber sobre a verdade. 0 fato de eu nunca ter me compreendido como branca me influenciou a buscar o paradeiro da minha herança racial.

A minha avó sempre habitou em mim através dos meus signos. A identificação deles me habilitou a reproduzir uma memória racial que hoje está viva. Posso dizer que o meu olhar sobre mim permitiu com que eu quebrasse uma pedagogia de assimilação que se arrastava há duas gerações na minha família. Foi este exercício que me libertou das pesadas correntes feitas de memórias branqueadas.

O espelho oferece a oportunidade de descobrir-se em si mesmo, mas isso só acontecerá se o desejo clamar por verdade, que, por sua vez, só é passível de reivindicação se o olhar sobre o próprio corpo for descolonizado. E, para que o olhar sobre si seja descolonizado, é preciso ter consciência sobre a própria história.

Devido à colonização subjetiva fomos impedidos de seguirmos os rastros sobre quem somos. Estamos seguindo passos fora de nossas histórias e fora do nosso terreno de experiência. Não temos consciência sobre quem somos porque desconhecemos a nossa história. Contudo, não podemos seguir nossa caminhada de mãos dadas com os colonizadores (vistos como salvadores), com os ditadores (ditos como heróis), tampouco com todas as figuras que hoje representam juntamente o autoritarismo, a imagem do branco europeu heterossexual.

A memória sobre as nossas linhagens não brancas é tanto uma luta contra a manipulação da verdade histórica como um grito por conscientização de que a colonialidade não foi superada com a independência. É uma forma de reavivar a memória de nossos corpos destruída pelo contínuo processo colonizador da mestiçagem. Afinal, muitos são os brasileiros que ainda permanecem em coma induzido com sintomas proeminentes de falta de memória e perda de identidade. 
Parir o seu primeiro filho sozinha foi o último universo da minha avó para com o seu povo. Ao retomar esta prática exercida pelas mulheres indígenas fulni-ôs, minha avó quis dizer que não abdicou de quem era. Sua segunda aposta para o futuro foi através do meu corpo. Eu sou a neta mais parecida com ela e isso significa que ela está falando através do meu corpo, por meios dos meus signos, que está viva.

Por todas estas razões, busco uma memória capaz de desmontar os mecanismos de censura impostos à coletividade que cortaram os fios que entrelaçavam as histórias familiares, as quais davam continuidade a uma trama ancestral (SEGATO, 2007b).

Refiro-me a uma memória que nos ensine a amar e a nos orgulhar, e não a matar dentro de nós quem amamos, quem faz parte da nossa história. Verso sobre uma memória que afaste a amnésia afetiva e que nos oriente a seguir nossos verdadeiros rastros. Ou seja, os rastros de nossas origens. Em rumo a esta jornada, indago: como poderíamos construir uma memória que habita em nós? 


\section{CONSIDERAÇÕES FINAIS}

A modernidade surgiu sob o contexto de violência colonialista que, ao construir uma sociedade racista, fundada na suposta ideia de superioridade racial, moral e intelectual europeia, segregou e extinguiu diversos grupos. Essa tentativa de extermínio estruturada no racismo forjou identidades a partir da fundação de estereótipos de inferioridade que ainda sobrevivem no imaginário da nação e na subjetividade das pessoas.

Sob essa ótica, cumpre afirmar que a marca da modernidade foi a violência. Esta não está aprisionada no tempo pretérito, muito pelo contrário, está presente em diversos segmentos sociais e, sobretudo, dentro de nós. 0 conjunto crucial de estratégias coloniais foi a de sequestrar nosso espelho, para assim conseguir total eficácia na interceptação e bloqueio das memórias, já que o que garante a nossa captura permanente pela colonialidade é a censura do autoconhecimento. Esta impossibilita que nos conectemos com as linhagens que nos constituem.

Neste seguimento vale arrematar que a colonialidade é profunda, é inegável, é evidente. Basta interpelar sobre as origens raciais e a maneira de identificar-se. Quem é você? Qual é a sua origem? Aparentemente são perguntas óbvias que, no entanto, demandam respostas absurdamente complexas, principalmente quando se desconhece a própria memória familiar. Como seria possível identificar-se como "negro", "índio", "branco" ou "mestiço" se não se sabe de onde veio?

No Brasil é vasta a quantidade de histórias de vida órfãs de suas linhagens raciais. Poucas foram as famílias que conseguiram preservar suas memórias em seus seios familiares. 0 sangue não branco, sequestrado por meio da mestiçagem compulsória, censurou a memória (física, psíquica e afetiva) de nossos corpos. Além do apagamento subjetivo, houve também o histórico. A memória histórica racial ocorreu perante o silenciamento do Estado. Vale dizer que a fragmentação das nossas memórias pessoais estão ligadas às ações racistas do Estado, principalmente no que se refere ao modo de se constituir memórias familiares. 
Este não saber sobre a raça nasce da ausência. Esta, por sua vez, só existe porque o mundo moderno é feito do "um": uma história (europeia), uma versão dessa história (vencedores), uma voz que narra a história (branca).

A história da colonização das Américas que estudamos na escola apresenta uma única versão narrada pelos colonizadores: a que glorifica o projeto civilizatório. Nesse período de aprendizagem não estudamos a verdadeira história: a do massacre, a do extermínio dos povos originários. Além disso, são poucas as referências sobre as rebeliões, revoltas, insurreições, manifestações populares e outros tipos de lutas que contemplaram questões raciais, étnicas e de gênero.

0 roubo de histórias de vida ocorreu neste processo de formação de uma única história ${ }^{64}$ que é sempre hegemônica e, portanto, universal. Contudo, vale indagar o quanto reforçarmos essa única narrativa. Até onde vai o nosso interesse em saber sobre nós mesmos? Ao negligenciar nossas memórias raciais - mesmo que este processo seja inconsciente, pois, como já assinalado, a mestiçagem subjetiva foi compulsória - estamos alimentando o motor da colonialidade.

Quando nos vemos como brancos e nos afirmamos brancos não estamos apontando a nossa identidade, e sim mostrando o quanto assimilamos uma única história. A nossa história colonial está marcada em nossos corpos e alcança a todos que nasceram em territórios colonizados. Logo, por mais que a pessoa tenha uma cor branca e tenha quatro avôs europeus, ela não será vista como branca em solos imperiais (SEGATO, 2010).

Nesse sentido, o processo de identificação consciente requer o conhecimento sobre a própria história, ou seja, narrada ou escrita por nós e não pelo outro branco europeu. O Brasil é um país com falhas de memória sobre diversos eventos do passado, em especial, sobre barbárie colonial. Nossa memória coletiva teve suas raízes raciais amputadas e nossa memória particular perdeu o sentido "de ser".

0 direito humano de saber quem se é consiste numa luta contra uma única narrativa, contra uma única história. Esse direito não positivado, que ainda está em fase de germinação, visa impedir que nossos laços de parentesco permaneçam apagados das nossas histórias de vida.

\footnotetext{
${ }^{64}$ A escritora nigeriana Chimamanda Adichie é reconhecida pela discussão sobre o perigo de uma única história.
} 
Trata-se de um direito que não nasce a partir do Estado, mas da insatisfação, da dor, ou seja, de um exercício de autoconhecimento que se consubstancia num impulso ético. Ele se contrapõe às concepções abstratas do direito (jusnaturalismo e juspositivismo), ao discurso homogêneo sobre os direitos humanos e ao tempo da modernidade.

Por essa razão, o referido direito é capaz de contestar a linguagem colonial dos direitos humanos. A reivindicação da devolução da consciência sobre as linhagens não brancas pode desnaturalizar a programação histórica normativa sobre o direito à memória, possibilitando o reconhecimento das memórias sufocadas que clamam pela verdade histórica.

A dimensão desse processo abarca discussões que contestaram a história dos direitos humanos como um retrato da historiografia europeia. Sabe-se que a formulação histórica desses direitos se baseia em violações perpetradas durante a Segunda Guerra Mundial e não em violações - tão desumanas quanto - cometidas durante a colonização, como a escravidão dos povos da África, da Ásia e das Américas.

Diante disso, as únicas lutas em prol dos direitos humanos que constituem a memória histórica desses direitos são as europeias (Revolução Francesa e Britânica) e a norte-americana. As demais revoluções, como a "Revolução Americana do Haiti", foram marginalizadas.

Portanto, a construção dos direitos humanos está estritamente vinculada às experiências modernas europeias. 0 "outro" é sempre situado no passado, uma vez que seu signo racial simboliza um atraso temporal. Esse passado se situa fora da modernidade.

Contudo, falar de modernidade não significa falar apenas da Europa. Não se pode esquecer que o colonialismo é tão moderno quanto às instituições liberais e que a Europa moderna (império) não teria sido constituída sem suas relações violentas com as colônias.

Apontar para a inexistência de uma memória que verse sobre as nossas origens raciais é indagar: quando o processo de civilização deixará de ser defendido como modernidade, como um ato glorioso, e passará a ser classificado como violência, ou seja, como um ato de barbárie?

Ao buscar uma memória que ressignifique nossas heranças raciais e que nos conecte às nossas origens raciais censuradas por um Estado ideologicamente herdeiro 
de uma produção histórica racista, proponho um debate sobre a construção de uma memória que não se encontra dentro dos processos de gestão e de produção de sentido moderno sobre o passado que possui como objeto histórico os mortos.

A propósito, essa memória traz a visão de que a modernidade envolve uma pluralidade de experiências e de temporalidades. Não se restringe a uma história linear e progressista cumulativa, uma vez que se refere à diversidade, avanços e riquezas, principalmente no que diz respeito ao modo de rememorar de um Sul plural. Tampouco se trata também de uma memória que represente os mortos; na verdade, trata-se de um instrumento de resgate sobre a consciência do que deveria estar vivo em nós.

Conhecer e acessar a nossa memória histórica é um direito de todos. É um direito porque esta consciência está estritamente ligada ao entendimento sobre quem somos, ou seja, à nossa identidade. A identidade própria - aquela que não se confunde com o desígnio nacional - nasce da reflexão, de um processo de autoconhecimento. Contudo, quando estamos sob o efeito da homogeneidade imaginária, este exercício é bloqueado. Por isso, é importante resgatar a consciência sobre a nossa experiência etnocida.

Sob esse prima, o direito humano de saber quem se é consiste no marco histórico da memória sobre as nossas origens que ainda não temos. É um direito contra a essencialização e a naturalização de identidades branqueadas. Seu papel é de romper com a pedagogia do silêncio ao informar a verdade sobre o passado e, sobretudo, de proporcionar a reconstrução de subjetividades fragmentadas por estereótipos negativos.

Este trabalho é uma discussão que acusa um roubo subjetivo. Portanto, a busca é por caminhos de memórias que permitam com que nos compreendamos e nos aproximemos de nós mesmos. Neste sentido, deixo a seguinte indagação: como manter vivo dentro de nós o nosso legado racial? 


\section{REFERÊNCIAS}

ABUELAS DE PLAZA DE MAYO. Historia de Abuelas. Disponível em: http://www.abuelas.org.ar/institucional.php?institucional=historia.htm\&der1=der1_his t.php\&der2=der2_inst.php. Acesso em: 07 jul. 2015.

ALVES, J. A. A Conferência de Durban contra o Racismo e a responsabilidade de todos. Revista Brasileira de Política Internacional, v. 45, n. 2, p. 198-223, 2002.

ARGENTINA. Ministerio de la Educación de la Nación. ¿Quien soy yo? Buenos Aires: Ministerio de Educación de la Nación, 2010.

ARISTÓTELES. Política. São Paulo: Martin Claret, 2002.

BALDI, C. A. Descolonizando o Ensino de Direitos Humanos? Hendu - Revista LatinoAmericana de Direitos Humanos, v. 5, n. 1, p. 8-18, 2014.

BOBBIO, N. O Positivismo Jurídico: Lições de filosofia do direito. São Paulo: Ícone, 1995.

BORIS, G. D.; CESIDIO, M. H. Mulher, corpo e subjetividade: uma análise desde o patriarcado à contemporaneidade. Revista Mal-Estar e Subjetividade, Fortaleza, v. 7, n. 2, set. 2007.

BRASIL. Constituição da República Federativa do Brasil. Diário Oficial da República, 5 out. 1988. Disponível em:

<http://www.planalto.gov.br/ccivil_03/Constituicao/Constituicao.htm>. Acesso em: 01 abr. 2011.

. Ministério da Educação e Cultura. Diretrizes Curriculares Nacionais para a Educação das Relações Étnico-Raciais e para o Ensino da História Afro-Brasileira e Africana. Brasília: SECAD/ME, 2004. Disponível em: http://portal.mec.gov.br/secadi. Acesso em: 14 jan. 2015.

Lei no 11.645, de 10 de março de 2008. Altera a Lei no 9.394, de 20 de dezembro de 1996, modificada pela Lei no 10.639 , de 9 de janeiro de 2003, que estabelece as diretrizes e bases da educação nacional, para incluir no currículo oficial da rede de ensino a obrigatoriedade da temática "História e Cultura Afro-Brasileira e Indígena". Brasília, Diário Oficial da União, 11 mar. 2008, p. 1. Disponível em: http://legislacao.planalto.gov.br/legisla/legislacao.nsf/Viw_Identificacao/lei\%2011.645 -2008?OpenDocument. Acesso em: 14 jan. 2015. 
Ministério da Educação e Cultura. Plano Nacional das Diretrizes Curriculares Nacionais para a Educação das Relações Étnico-raciais e para o Ensino de História e Cultura Afro-brasileira e Africana. Brasília: SECAD; SEPPIR, jun.2009.Disponível em: http://portal.mec.gov.br/secadi. Acesso em: 14 jan. 2015.

Programa Nacional de Direitos Humanos 3 (PNDH-3). Brasília: Secretaria de Direitos Humanos da Presidência da República, 2010. Disponível em: http://www.pndh3.sdh.gov.br/public/downloads/PNDH-3.pdf. Acesso em: 15 jan. 2015.

CANÇADO TRINDADE, A. Dilemas e desafios da proteção internacional dos direitos humanos. In: SOUSA JR., J. G. et al. Educando para os direitos humanos: pautas pedagógicas para a cidadania na universidade. Porto Alegre: Síntese, 2004. v. 1.

CANDAU, J. Memória e Identidade. São Paulo: Contexto, 2012.

CLAVERO, B. Bartolomé Clavero: Ensayos, informes. Disponível em: http://www.bartolomeclavero.net/?cat=10. Acesso em: 15 jan. 2015.

COMPARATO, F. K. A afirmação histórica dos Direitos Humanos. São Paulo: Saraiva, 2011.

CONSELHO INDIGENISTA MISSIONÁRIO (CIMI). Relatório Violência contra povos indígenas no Brasil. Dados de 2014. Brasília: Cimi, 2015.

CORTE INTERAMERICANA DE DIREITOS HUMANOS. Caso Gomes Lund e outros (“Guerrilha do Araguaia”) vs. Brasil. Sentença de 24 de novembro de 2010. Disponível em: http://www.corteidh.or.cr/docs/casos/articulos/seriec_219_por.pdf. Acesso em: 07 jul. 2015.

CRESWELL, J. Projeto de pesquisa: método qualitativo, quantitativo e misto. 2. ed. Porto Alegre: Artmed, 2007.

CURIEL, O. Hacía la construcción de un feminismo descolonizado. In: MIÑOSO, Y. E. (coord). Aproximaciones críticas a las prácticas teórico-políticas del feminismo latinoamericano. Buenos Aires: En la Frontera, 2010. v. 1.

DE BAETS, A. 0 impacto da Declaração Universal dos Direitos Humanos no estudo da História. História da Historiografia, v. 5, p. 86-114, set. 2010.

DECLARAÇÃo E PROGRAMA DE AÇÃo adotados na III Conferência Mundial de Combate ao Racismo, Discriminação Racial, Discriminação Racial, Xenofobia e Intolerância Correlata. Durban, 31 de agosto a 8 de setembro de 2001. Disponível em: <http://www.oas.org/dil/port/2001\%20Declara\%C3\%A7\%C3\%A3o\%20e\%20Progra ma\%20de\%20A\%C3\%A7\%C3\%A3o\%20adotado\%20pela\%20Terceira\%20Confer\%C3 \%AAncia\%20Mundial\%20contra\%20o\%20Racismo,\%20Discrimina\%C3\%A7\%C3\%A3 
o\%20Racial,\%20Xenofobia\%20e\%20Formas\%20Conexas\%20de\%20Intoler\%C3\%A2n cia.pdf>. Acesso em: 01 set. 2014.

DEVEREUX, G. Los desordenes étnicos. Ensayos de Etnopsiquiatría. Barcelona: Barral Ediciones, 1971.

DU BOIS, W. E. B. The Souls of Black Folk. Authoritative Text. Contexts. Criticisms. New York: W. W. Norton \& Co, 1999.

DUSSEL, E. Política de la liberación I - Historia Mundial y Crítica. Madrid: Trotta, 2007.

FAERMAN, L.; WEIS, M. Povos indígenas e a ditadura militar. Algazarra (Prod.). Canal Futura, Sala de Notícias, 04 fev. 2015. Disponível em:

https://www.youtube.com/watch?v=M0jtsgSsxFs. Acesso em: 06 jul. 2015.

FANON, Frantz. Pele negra, máscaras brancas. EdUFBA, 2008.

FEIERSTEIN, D. El genocidio como práctica social: entre el nazismo y la experiencia argentina: hacia un análisis del aniquilamiento como reorganizador de las relaciones sociales. Buenos Aires: Fondo de Cultura Económica, 2011.

FLAUZINA, A. L. P. As Fronteiras Raciais do Genocídio/The Racial Boundaries of Genocide. Revista Direito. UnB, v. 1, n. 1, 2014.

FOUCAULT, M. Em defesa da sociedade: curso no College de France (1975-1976). São Paulo: Martins Fontes, 2005.

Microfísica do poder. 25. ed. São Paulo: Graal, 2012.

FREIRE, P. Extensión o comunicación. São Paulo: Icira, 1969.

FLOR DO NASCIMENTO, Wanderson. Por uma vida descolonizada: diálogos entre a bioética de intervenção e os estudos sobre a colonialidade, 2011.

GENOCÍDIO ARMÊNIO. Quem reconhece. Disponível em:

http://genocidioarmenio.com.br/historia/quem-reconhece/. Acesso em: 07 jul. 2015.

GIL, A. C. Estudo de caso: fundamentação científica subsídios para coleta e análise de dados como redigir o relatório. São Paulo: Atlas, 2009.

GONZÁLEZ REY, F. Pesquisa qualitativa e subjetividade: os processos de construção da informação. São Paulo: Pioneira Thomson Learning, 2005.

GROSSI, M. P. Trabalho de campo e subjetividade. Florianópolis: Universidade Federal de Santa Catarina, 1992. 
HALBWACHS, M. A memória coletiva. São Paulo: Centauro, 2004.

HARDING, S. G. Feminism and methodology: Social science issues. Indiana University Press, 1987.

HARTOG, F. El tiempo de las víctimas. Revista de Estudios Sociales, n. 44, p. 12-19, 2012.

HASTRUP, K. Human Rights, History of. 2001. Disponível em: http://www.inth.ugent.be/wp-content/uploads/2012/05/History-of-HumanRights.pdf. Acesso em: 07 jul. 2015.

HERRERA FLORES, J. La reinvención de los derechos humanos. Andalucia: Atrapasueños, 2008.

HUNT, L. A invenção dos Direitos Humanos: uma história. São Paulo: Companhia das Letras, 2009.

LANDER, E. (org.). La colonialidad del saber: eurocentrismo y ciencias sociales. Perspectiva slatinoamericanas. Buenos Aires: CLACSO/UNESCO, 2000.

. A colonialidade do saber: eurocentrismo e ciências sociais. Perspectivas latinoamericanas. In: ___. Colección Sur Sur. CLACSO, Ciudad Autónoma de Buenos Aires, Argentina. set. 2005.

LEVI, P. É isto um homem? Rio de Janeiro: Rocco, 1988.

LYRA FILHO, R. 0 que é direito. São Paulo: Brasiliense, 2006.

MALDONADO-TORRES, N. Sobre la colonialidad del ser: contribuciones al desarrollo de un concepto. El giro decolonial. Reflexiones para una diversidad epistémica más allá del capitalismo global, p. 127-167, 2007.

MARIATEGUI, J. C. Ideología y política.Santiago de Chile: Centro de Estudios Miguel Enriquez, 1971 [1915]. Disponível em:

https://www.marxists.org/espanol/mariateg/oc/ideologia_y_politica/paginas/tesis\%2 0ideologicas.htm\#1. Acesso em: 07 jul. 2015.

MARÍN, J. J; DEL CAIRO, C. Los dilemas de la museificación. Reflexiones en torno a dos iniciativas estatales de construcción de memoria colectiva en Colombia. Memoria y Sociedad, v. 17, n. 35, 2013.

MIGNOLO, W. D. "Un paradigma otro": colonialidad global, pensamiento fronterizo Y cosmopolitanismo critico. Dispositio, p. 127-146, 2005. 
Desobediencia epistémica: retórica de la modernidad, lógica de la colonialidad y gramática de la descolonialidad. Ediciones del Signo, 2010.

MINISTERIO DE LA EDUCACIÓN [de la Nación Argentina]. Presidencia de la Nación. Pensar la dictadura: terrorismo de Estado en Argentina. Buenos Aires: Ministerio de la Educación de la Nación Argentina, 2010.

MINISTÉRIO PÚBLICO FEDERAL. Relatório Figueiredo. Disponível em: http://6ccr.pgr.mpf.mp.br/institucional/grupos-detrabalho/gt_crimes_ditadura/relatorio-figueiredo. Acesso em: 15 jan. 2015.

NORA, P. Entre memória e história: a problemática dos lugares. Revista do Programa de Estudos de Pós-Graduados em História, São Paulo, v. 10, 1993. Disponível em: http://revistas.pucsp.br/index.php/revph/article/view/12101. Acesso em: 07 jul. 2015.

OLIVEIRA, R. C. 0 trabalho do antropólogo. São Paulo: Unesp, 1996.

PABLO III. Sublimis Deus. 02 jun. 1537. Disponível em:

http://webs.advance.com.ar/pfernando/DocsIglLA/Paulo3_sublimis.html. Acesso em: 07 jul. 2015.

POLLAK, M. Memória, esquecimento, silêncio. Revista Estudos Históricos, v. 2, n. 3, p. 3-15, 1989.

QUIJANO, A. Raza, Etnia y Nación en Mariátegui: Cuestiones abiertas. In: FORGUES, R. (Ed.). José Carlos Mariátegui y Europa. La otra cara del descubrimiento. Lima: Editorial Amauta, 1993.

. Raza, etnia y nación en Mariátegui: cuestiones abiertas. Estudios latinoamericanos, v. 2, n. 3, p. 3-19, 1995.

Que tal raza. Familia y cambio social. Lima: CECOSAM, 1999.

. Colonialidad del poder, eurocentrismo y América Latina. In: LANDER, E. (comp.). La colonialidad del saber: eurocentrismo y ciencias sociales. Perspectivas latinoamericanas. Buenos Aires, CLACSO, 2000.

QUIJANO, A.; WALLERSTEIN, I. La americanidad como concepto, o América en el moderno sistema mundial. Revista Internacional de Ciencias Sociales, p. 1492-1992, 1992.

ROCHA, E. P. G. 0 que é Etnocentrismo? 5. ed. São Paulo: Brasiliense, 1988. [Coleção Primeiros Passos]. 
RUFER, M. La temporalidad como política: nación, formas de pasado y perspectivas poscoloniales. Mem. Soc., Bogotá, v. 14, n. 28, p. 11-31, Enero/Junio 2010.

La memoria de los otros: Subalternidad, poscolonialismo y regímenes de

verdad. Revista de Estudos AntiUtilitaristas e PosColoniais, v. 1, n. 1, p. 13-43, 2011.

SÃO PAULO. Assembléia Legislativa. Comissão da Verdade do Estado de São Paulo "Rubens Paiva". Infância roubada: crianças atingidas pela ditadura militar no Brasil. São Paulo: ALESP, 2014.

SÁNCHEZ BOTERO, E. Mucho derecho y poca antropología: el impacto negativo, en sociedades étnicas, del derecho globalizado", Inédito.

SCHWARCZ, L. M. Racismo no Brasil. São Paulo: Publifolha, 2013.

SEGATO, R. L. Por que reagimos às cotas para negros? 0 público e o privado, n. 3 , Jan../Jun. 2004.

Raça é signo. Brasília: UnB, 2005. [Série Antropologia, n. 375].

Antropologia e Direitos Humanos: alteridade e ética no movimento de expansão dos direitos universais. Mana, Rio de Janeiro, v. 12, n. 1, p. 207-236, abr. 2006a.

. O Édipo brasileiro: a dupla negação do gênero e da raça. Brasília: UnB, 2006b. [Série Antropologia, n. 400].

. El color de la cárcel en América Latina. Apuntes sobre la colonialidad de la justicia en un continente en desconstrucción. Revista Nueva Sociedad, n. 208, 2007a.

La nación y sus otros: raza, etnicidad y diversidad religiosa en tiempos de políticas de la identidad. Prometeo Libros Editorial, 2007b.

. Los cauces profundos de la raza latinoamericana: una relectura del mestizaje. Crítica y Emancipación, v. 2, n. 3, 2010.

Gênero e colonialidade: em busca de chaves de leitura e de um vocabulário estratégico descolonial. Cadernos CES, n. 18, 2012.

Aníbal Quijano y la perspectiva de la colonialidad del poder. Revista Casa de las Américas, n. 272, 2013.

SILVA, M. L.; KALCKMANN, S. Racismo e os efeitos na saúde mental. In: Temas em Saúde Coletiva. São Paulo: Instituto de Saúde, 2005. p. 129-132. 
SOUZA, N. S. Tornar-se negro, ou, As vicissitudes da identidade do negro brasileiro em ascensão social. Rio de Janeiro: Graal, 1983.

SOUSA SANTOS, B. Um discurso sobre as ciências. Porto: Afrontamento, 1987.

SPIVAK, G. C. Pode o subalterno falar? Belo Horizonte: UFMG, 2010.

UNITED STATES HOLOCAUST MEMORIAL MUSEUM. Home. Disponível em: http://www.ushmm.org/. Acesso em: 07 jul. 2015.

WALLERSTEIN, I. Geopolítica y geocultura: ensayos sobre el moderno sistema mundial. São Paulo: Kairós, 2007. 